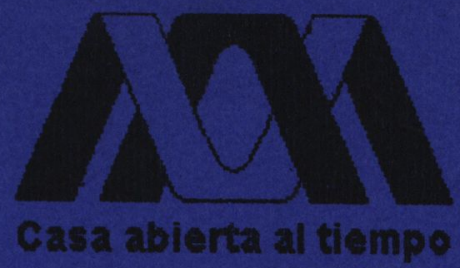

UNIVERSIDAD AUTÓNOMA METROPOLITANA

UNIDAD IZTAPALAPA

DIVISIÓN DE CIENCIAS SOCIALES Y HUMANIDADES

POSGRADO EN CIENCIAS ANTROPOLÓGICAS

\author{
"De cuerpo presente" \\ Adriana Guzmán Vázquez
}

Tesina de Maestría en Ciencias Antropológicas

Director: Dr. Sergio Pérez Cortés

Asesores: Dra. Nicole Marie Ooms Renard

Dr. José Luis Vera Cortés

México, D.F.

Diciembre del 2002 


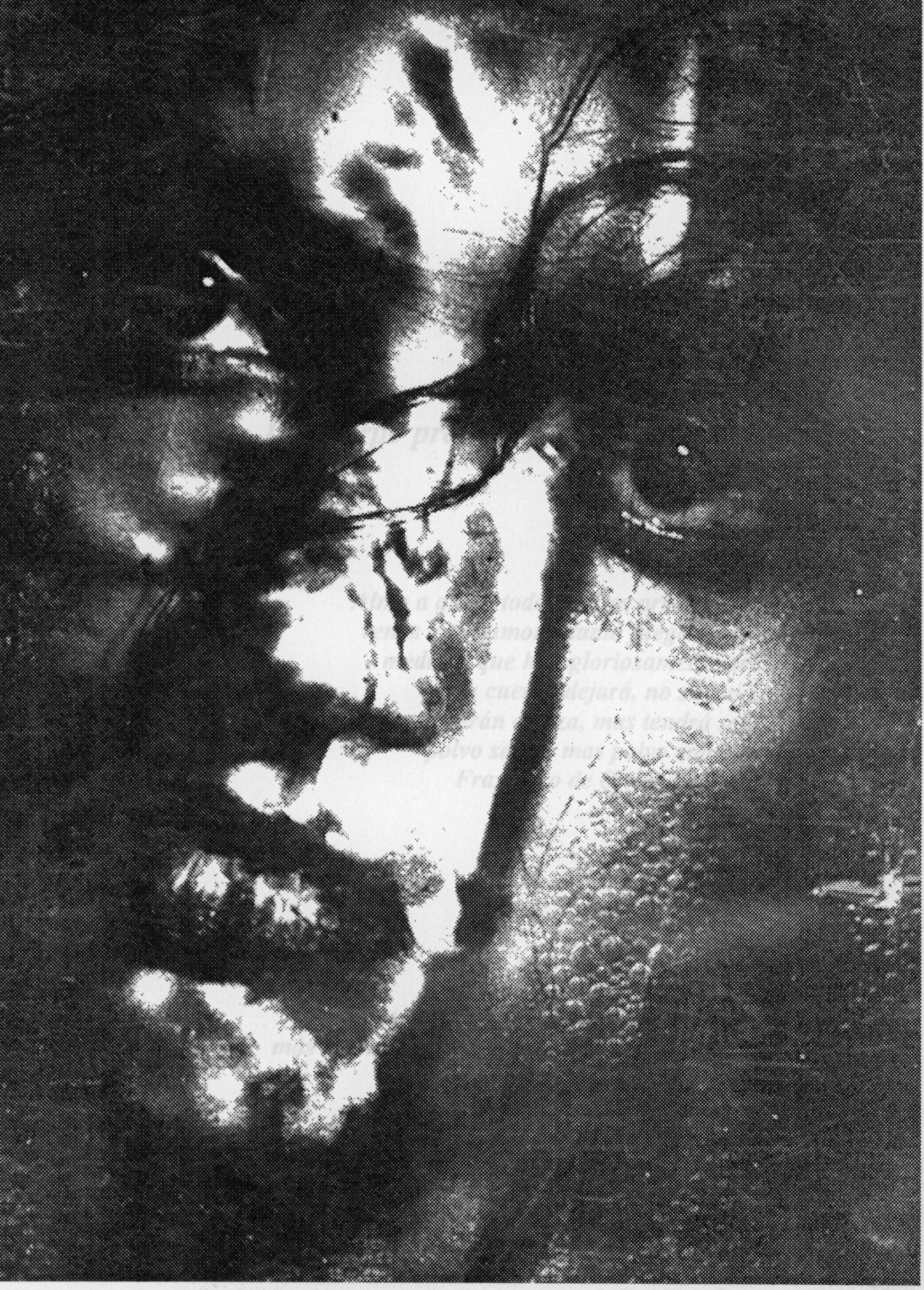




\section{De cuerpo presente}

Alma a quien todo un dios prisión ha sido, venas que humor a tanto fuego han dado, medulas que han gloriosamente ardido, su cuerpo dejará, no su cuidado; serán ceniza, mas tendrá sentido; polvo serán, mas polvo enamorado.

Francisco de Quevedo y Villegas

Mientras más se alejan los hombres de dios, más avanzan en el conocimiento de las religiones.

Cioran 


\section{Índice}

Desde el alma

Preámbulo

Percepciones

introducción

La mirada

marco conceptual

El cuerpo

Bibliografia 


\section{Índice de ilustraciones}

1.- Portada

2.- La culpa. Intérprete: Kazuo Ono. Foto: Christa Cowrie.

3.- El pecado. Intérprete: Marco Antonio Silva. Foto: Heredia.

4.- Pecado mortal. The struggle. Foto: Robert Demachy.

5.- Confesión. Domingo Rubio. Foto: José Murguía.

6.- Penitencia. L'Arche de Noé (foto no acreditada).

7.- Sacrificio individual. Cielo. Foto: Gerardo Suter.

8.- Sacrificio colectivo. Ballet del siglo XX de Maurice Béjart. Foto: Christa Cowrie.

9.- La caída. Intérprete: Kazuo Ono. Foto: Christa Cowrie.

10.- La caida. Intérprete: Kazuo Ono. Foto: Christa Cowrie.

11.- La caída. Intérprete: Kazuo Ono. Foto: Christa Cowrie.

12.- La caida. Intérprete: Kazuo Ono. Foto: Christa Cowrie.

13.- La caída. Intérprete: Kazuo Ono. Foto: Christa Cowrie.

14.- La caida. Intérprete: Kazuo Ono. Foto: Christa Cowrie. 


\section{Desde el alma}

Amorosamente agradezco a quienes de una manera u otra han estado por ahí a lo largo de tan ajetreada trayectoria:

En principio, por supuesto, a Sergio Pérez Cortés, también "culpable", por su apoyo constante, desde que buscaba ingresar al posgrado, hasta en estos momentos. Además, sirva también como un profundo reconocimiento a su seriedad, profesionalismo y buena disposición. Sergio, siempre me han sido vitales tus comentarios. Mil gracias por todo.

José Luis Vera Cortés y Nicole Ooms apoyadores, viejos conocidos; por su solidaridad e interés, mil gracias. Víctor Franco quien impulsó los inicios de este proyecto.

Arturo y Guadalupe quienes, a su manera, siempre están presentes.

Diana, obviamente. Las Cristinas y compañía, invariablemente cálida recepción. Roberto y Blanca, solidarios. Javier, de quien además aprecio enormemente su calidez y profesionalismo. Ricardo, cuya cercanía me es profunda e invaluable. Mari Paz, nuevamente presente en este trabajo además de la fortuna de saberla en movimiento. Nuevamente y por siempre a la Escuela Activa y sus confabuladores. Eva, Helena, Dany, Guity, Carlos Hugo, que por ahí andan cada uno a su manera. Sergio, Claudia, Alejandra, Memo, Alfredo, Alberto, Carmen, Ramón, Juanjo, también.

Sin ustedes, ¿cómo? 


\section{Preámbulo}

El cuerpo... siempre el cuerpo: polivalente, polisémico, polifónico, polícromo, poliédrico... maravilloso universo del ser. Quién que sea no es en un cuerpo. Afirmación recurrente que le da cuerpo a este discurso del cuerpo que además presenta cuerpos. El cuerpo... siempre el cuerpo.

Confabulado para dar cuenta de algunas de las múltiples aristas que conforman el infinito universo que es tema del presente trabajo, el texto aborda distintas miradas que le han ido dando cuerpo al cuerpo; construcción de propio compleja que ha requerido que lo presente dividido en dos grandes partes --más su introducción--. En el primer capítulo he buscado hablar del cuerpo y en el segundo he dejado que él hable por sí mismo.

A manera de introducción aparecen los discursos que han sido contundentes en la construcción del cuerpo, lo cual permite ubicar el universo en el que se insertan los planteamientos del primer capítulo, que es la mirada conceptual, misma en la que enuncio la postura que tomo para elaborar el análisis que desarrollo en el segundo capítulo del texto.

Ante la complejidad de las formas en las que el cuerpo se construye, en el análisis decidí abordarlo a partir de la construcción discursiva y vivencial del, igualmente complejo, universo de la culpa debido a que ésta ha sido contundente en la conformación de los sujetos en occidente; además, como he querido que el cuerpo hable por sí mismo, también en este capítulo presento fotos en las que los propios cuerpos ilustran aquello de lo que hablo: representaciones de las formas en las que se construyen los cuerpos culpables retomadas de la danza escénica, por ser ella paradigmática en la construcción de discursos con el cuerpo.

De esta manera me ha sido posible presentar los distintos vericuetos a los que me ha llevado la investigación y que sé, es apenas un primer acercamiento pues queda todavía mucho por trabajar para seguir dando cuenta de ese fascinante mundo que es el cuerpo... siempre el cuerpo. 


\section{Percepciones \\ introducción}

Sólo se deberían escribir libros

para decir cosas que uno no se atrevería a confiar a nadie.

Cioran

Evidente, tangible y contundente. El cuerpo, centro de discusión u omisión total. El cuerpo, ese ineludible dato que nos enfrenta a una realidad que ha buscado negarse o exaltarse; según las épocas y sus saberes, según como se ha decidido interpretar la experiencia; el cuerpo, inevitablemente, se incardina como bucle en cuyas tangibles y resbaladizas siluetas se conforma el sujeto.

Quién es que no sea en su cuerpo, qué historia es siquiera imaginable sin cuerpo, que corpus se vive sin cuerpo; cuántos cuerpos se viven o de qué manera se vive el propio. Desde algún lugar podría aseverarse que este mundo es una encrucijada de cuerpos que se observan, se tocan, caminan ajenos, de la mano, se hablan, se hablan y se hablan. Qué es el cuerpo: el origen de la respuesta se encuentra en la Torre de Babel.

Desde cierta perspectiva, la historia del cuerpo es la de la humanidad misma; sin embargo, no hay respuestas precisas ante construcciones complejas y permanentes; quizá, con suerte, habrá que acercarse a cierto paradigma que algo diga al respecto; buscar los discursos sobre el cuerpo, los de sus múltiples interpretaciones. Bajo qué parámetros resguardarse para poder descifrar el casi imperceptible e infinito continuum de la existencia del cuerpo; dónde encontrar puntos sólidos, tangibles quizá, para su lectura.

Hacer uso de la palabra para referirse a una entidad que elabora su propio discurso me coloca en la paradoja que, siempre que se actúa de esa manera, aparece como inevitable: la transformación de códigos en los que algo se pierde y algo se gana. Deseo hablar del cuerpo y también quiero dejar que el cuerpo hable. Aparece aquí una nueva y alegórica paradoja, pues se habla del cuerpo como entidad independiente cuando en realidad es el propio cuerpo el que habla; es decir, no hay sujeto sin cuerpo ni cuerpo sin sujeto, pero se revisan como entes separados. Lo fascinante aquí es encontrarse en la exclusividad del objeto a tratar, es decir, el único en donde, esencialmente, el objeto conocido es el mismo que el sujeto cognoscente.

El cuerpo es lo que es también a partir de lo que de él se ha dicho y se diga, se ha pensado y se piensa, se ha creído y se crea. El cuerpo es movimiento, o es porque está en movimiento. Dirá Rudolf von Laban que es un ente con un peso definido que se encuentra en un espacio ocupado por la horizontalidad, verticalidad y sagitalidad de sus ejes; en un tiempo marcado por la intensidad, la frecuencia y la transición de su flujo, o movimiento. Pero esto es sólo un principio.

Hablar del cuerpo puede querer decir cualquier cosa, hasta el riesgo de no decir nada. Esa es la perpetua amenaza del cuerpo: tan es todo, que puede ser nada. $\mathrm{Al}$ menos es 
el legado que actualmente pervive con mayor fuerza. Ya sea por una exaltación de lo propiamente humano -Descartes-- ${ }^{1}$, ya sea por una valoración de su infinita capacidad sustentada en algo legítimo -Kant--2, ya sea por un teológico intento de buscar la verdad Santo Tomás de Aquino-- ${ }^{3}$, ya sea por una auténtica orientación dominante -tradición judeocristiana- ${ }^{4}$ ya sea por una honesta búsqueda de comprensión de la realidad positivismo--- 5 .

Si bien ha pesado en occidente una visión fragmentaria del cuerpo, ya no es novedad que los saberes se estén modificando; más o menos desde que Freud planteó que el yo es en la medida en que se encuentra encarnado y que la antropología volteó la mirada hacia otros tipos de conceptualizaciones del cuerpo, las formas de comprenderlo se han cambiado. En muchas de aquellas disciplinas en las que se entretiene la humanidad se han elaborado diversos y fructíferos planteamientos, así en la ciencia, la religión, las artes, las humanidades.

Dentro del psicoanálisis deben mencionarse las aportaciones de Freud ${ }^{6}$ y de Lacan ${ }^{7}$, las de Wallon sobre la conciencia del propio cuerpo, las de Piaget y su teoría del organismo, las de Schiller y su propuesta de imagen corporal, entre otras; igualmente cabe señalar a los denominados freudiano-marxistas ${ }^{8}$. Asimismo se encuentran, dentro de la

1 Descartes estaba convencido de que aquello que nos distingue como humanos es la razón, verbigracia, la antepuso a todo lo demás; concibió, ontológicamente hablando, la distinción entre mente y cuerpo y, epistemológicamente adujo que sólo conocemos nuestras propias ideas. Amén de establecer la noción del cuerpo como máquina.

${ }^{2}$ Kant establece la dicotomía entre el lado formal, conceptual e intelectual y el material, perceptivo y sensible -como la supone en su diferenciación entre la razón práctica y la pura-- y enarbola el predominio de la razón, que trasciende al cuerpo.

${ }^{3}$ Santo Tomás buscaba la verdad sólo posible en el espíritu que se guía por la palabra divina, el cuerpo es lo terrenal que impide llegar a Dios, verbigracia, una vez más.

${ }^{4}$ No es novedad señalar que, en buena medida, la continuidad y fuerza del judeocristianismo se debe a sus mecanismos de dominación en los que el control del cuerpo juega un papel fundamental.

5 Aunque ahora se tenga que cargar con la lápida de su legado, no puede negarse la honesta búsqueda del positivismo por escapar de las explicaciones metafísicas fundamentándose, única y exclusivamente, en la realidad empírica; sin embargo, actualmente su marca imposibilita la comprensión de aquello que no es un hecho directamente observable.

${ }^{6}$ La explicitación de la existencia de la sexualidad infantil y el predominio, marcado por Freud, de la líbido; así como las repercusiones en lo físico de los estados psíquicos, como los casos de histeria, colocaron al cuerpo en un nuevo sitio de observación.

${ }^{7}$ Lacan establece la fundamental importancia del cuerpo en la constitución del sujeto y su preponderante presencia en el perpetuo juego de los registros simbólico, imaginario y real.

${ }^{8}$ Como Wilhelm Reich y su teoría orgásmica del cuerpo y Marcuse y su reivindicación de la presencia de Eros. 
medicina, las propuestas sobre la psicosomaticidad de las enfermedades ${ }^{9}$. Dentro de la sociología-antropología aparecen los planteamientos de Marcel Mauss y su propuesta de estudio de las técnicas corporales; diversos estudios sobre clasificaciones ${ }^{10}$ al igual que los de cosmovisión ${ }^{11}$ y dentro de la semiótica o semiología -según escuelas- los copiosos planteamientos sobre comunicación no-verbal.

Asimismo, deben considerarse las renovaciones en cuanto a la visión y uso del cuerpo de las artes contemporáneas, tanto en la pintura como en la escultura pero, sobre todo, en las artes escénicas ${ }^{12}$ y en la literatura ${ }^{13}$. Por último y con especial énfasis deben señalarse los trabajos fenomenológicos, con particular atención a los de Gabriel Marcel, Sartre y Merleau-Ponty y, posteriormente, a los genealógicos como el de Foucault. Y la lista podría continuarse.

Como resultado, encuentro que en esta sociedad actual la construcción de los saberes sobre el cuerpo se concentran en cuatro grandes discursos interconectados que se nutren de muchos otros pero que resultan predominantes: el de las llamadas ciencias duras con especial énfasis en la medicina; el religioso, particularmente del judeocristianismo; el de las humanidades, con acento en la fenomenología, el psicoanálisis y la antropología y, el de las artes ${ }^{14}$, en especial aquellas que trabajan directamente con el cuerpo, como la danza y el teatro, además de la literatura y la plástica. De estos cuatro grandes saberes, los dos primeros son predominantes como lo es también su visión fragmentaria del cuerpo. La construcción de su saber, que se basa principalmente en la observación, resulta fragmentaria porque lo entiende como una entidad construida por partes que si bien se tocan, se encuentran separadas, llámense órganos o bien el incansable argumento de cuerpo y mente o espíritu. Los dos últimos, el humanismo y las artes han construido su conocimiento principalmente a partir de la confrontación y, quizá por ello mismo, hoy en día sostienen una visión holística del cuerpo, una totalidad en constante creación y transformación.

${ }^{9}$ Como los trabajos de Groddeck, Parcheminey, Seguin, Halliday y otros.

${ }^{10}$ Dentro de los que deben señalarse, por lo menos, los trabajos de Mary Douglas, Lévi-Strauss y Bourdieu.

${ }^{11}$ Como los de varios mesoamericanistas. Directamente relacionados con el cuerpo se encuentran los libros de López Austin.

${ }^{12}$ Por ejemplo las propuestas del "Living Theatre" y del teatro de la crueldad de Artaud; las técnicas de formación del actor de Grotowski y Stanislavski; la renovación de la mímica de Barrault o de Marceau y la liberación de la expresión corporal de Béjart, Duncan, Graham.

${ }^{13}$ Como la exaltación del erotismo, desde diferentes perspectivas, como la de Miller, Klossowski, Le Clézio o Bataille.

14 También las artes forman parte de las humanidades; sin embargo, aquí las observo de forma separada para poder distinguir los diferentes discursos. 
Sin embargo, pese a la gran labor de las humanidades y de las artes, la postura predominante continua siendo, en líneas generales, la creencia de que "existe una brecha entre nuestro lado cognitivo, conceptual, formal o racional y nuestro lado corporal, perceptivo, material y emocional. La consecuencia más significativa de esta escisión consiste en que todo significado, conexión lógica, conceptualización y razonamiento se alinean con la dimensión mental o racional, mientras que la percepción, la imaginación y la emoción se alinean con la dimensión corporal". (Johnson, 1991: 31).

Es menester entonces apelar a la unidad del sujeto, dejar de fragmentarlo; argumentar que el cuerpo no es un simple vehículo biológico sino la posibilidad de existencia del ser ya que "En tanto animales tenemos cuerpos conectados con el mundo natural, de tal modo que nuestra conciencia y nuestra racionalidad están vinculadas a nuestras orientaciones corporales y a nuestras interacciones con y en nuestro entorno. Nuestra corporeidad es fundamental con respecto a quiénes somos, a qué supone el significado y a nuestra capacidad de hacer deducciones racionales y a ser creativos" (Ibid: 46).

Las dimensiones horizontal, vertical y sagital -como las denomina Laban--, determinan la comprensión del arriba-abajo, atrás adelante, izquierda-derecha así como la kinesfera -nuevamente un término de Laban - da la orientación espacio-temporal de donde se derivan los esquemas de las imágenes que son patrones abstractos de la experiencia de vida y comprensión que surgen de la experiencia corporal. Es a partir de proyecciones metafóricas -donde metáfora se entiende no en el sentido dado por el objetivismo sino como "un principio incisivo de la comprensión humana que se erige en el fundamento de nuestra vasta red de significados literales interrelacionados, es un proceso de comprensión humana mediante el cual alcanzamos una experiencia significativa a la que podemos dotar de sentido"(Ibid: 131); en esta orientación empírica, "la metáfora es un proceso mediante el cual comprendemos y estructuramos una esfera de la experiencia en virtud de otra esfera de distinto tipo" (Ibid: 66)--, entonces, es a partir de proyecciones metafóricas que es posible asir la realidad.

Así, el significado, la comprensión y la razón son producto de proyecciones metafóricas de los esquemas de las imágenes propias del cuerpo; es decir, que aquello que se ha establecido como más independiente del cuerpo, como lo son los procesos de significación, también son producto de la experiencia interna y externa del cuerpo. De este modo, existen una serie de esquemas, sumamente dúctiles, que tienen que ver con la postura corporal y con las experiencias en torno a los haceres en, con y hacia el cuerpo. Para "reinsertar el cuerpo en la mente (es menester considerar que) la proyección imaginativa es un principio mediante el cual el cuerpo (es decir, la experiencia física y sus estructuras) elabora su ascenso hacia la mente (o sea, las operaciones mentales)". (Ibid: $45)$.

Las proyecciones metafóricas se ponen en funcionamiento a partir de los esquemas de las imágenes que son estructuras preconceptualmente significativas de la experiencia, es decir, patrones esquemáticos y proyecciones figurativas mediante las cuales la experiencia adquiere organización y conexión significativas, de tal modo que es posible entenderla y 
razonar sobre ella. Los esquemas de las imágenes son más abstractos y maleables que las descripciones mentales, se componen de una reducida cantidad de partes y relaciones en virtud de las cuales se pueden estructurar indefinidamente muchas percepciones, imágenes y acontecimientos; operan a un nivel de organización mental situado entre las estructuras proposicionales abstractas y las imágenes concretas particulares.

"Con el propósito de que tengamos experiencias significativas y conectadas que podamos comprender y sobre las cuales nos sea posible razonar, debe haber modelo y ordenamiento en nuestras acciones, percepciones y concepciones. Un esquema es un patrón recurrente, una forma y una regularidad en o de esas actividades de ordenamiento en curso. Estos patrones surgen como estructuras significativas principalmente a nivel de nuestros movimientos corporales en el espacio, nuestras manipulaciones de objetos y nuestras interacciones perceptivas" (Ibid: 86).

Los esquemas de las imágenes tienen un carácter dinámico, que es lo que permite organizar la experiencia y el entendimiento, son la estructura continua de una actividad organizadora y son dinámicos en dos sentidos "1) son estructuras de una actividad mediante la cual organizamos nuestra experiencia de manera que podamos comprender. En lugar de meros receptáculos pasivos en los que se vierte la experiencia, son el medio primario a través del cual construimos o constituimos el ordenamiento de la misma; 2) son flexibles en el sentido de que pueden incorporar cualquier cantidad de ejemplos específicos en diversos contextos. Es equívoco afirmar que el esquema de una imagen se llena con detalles perceptivos concretos; han de ser relativamente maleables a fin de modificarse para incorporar muchas situaciones parecidas pero distintas que muestran una estructura fundamental recurrente" (Ibid: 86).

Asimismo, los esquemas de las imágenes se crean en la experiencia corporal de distinta índole; así, la motricidad está siempre ligada de manera directa o indirecta a una experiencia emocional impuesta por una relación con otras personas o bien, las partes del cuerpo que las manos pueden alcanzar fácilmente difieren en su estructura psicológica de aquellas partes que sólo pueden alcanzar con dificultad; igualmente, las partes del cuerpo visibles son diferentes de aquellas que no lo son; por lo tanto, la adaptación emocional es esencialmente de origen postural.

"La conciencia que el niño tenga de su cuerpo dependerá de la conciencia de su personalidad y de las actitudes que los adultos le hayan recomendado adoptar frente al medio físico y al medio social. De manera que en el niño la imagen del cuerpo está modelada por las condiciones de vida y de pensamiento en las que lo colocan las técnicas, las usanzas, las creencias, los conocimientos, etcétera, propios de la época y de la civilización a la que pertenece". (Bernard, 1994: 58-59).

Bajo esta perspectiva, lo propio del cuerpo humano estriba en la capacidad de multiplicar mundos alrededor de él. "Esta consonancia entre el cuerpo y el mundo natural y cultural presupone que en el cuerpo mismo haya unidad, por una parte, entre los cinco sentidos, por otra parte, entre los cinco sentidos y el movimiento y por fin, entre esta sensoriomotricidad y la palabra" (Ibid: 73). El cuerpo es el vehículo de estar en el mundo, y 
tener un cuerpo significa para un ser vivo colocarse en un medio definido, confundirse con ciertos proyectos y emprender continuamente algo. En suma, el cuerpo es el eje del mundo.

Así como es a partir de experiencias corporales que se llega a la significación, la propia experiencia se ve definida, pues el individuo internaliza las determinaciones sociales. En esa medida es más que plausible indicar, como ya lo a hecho Mary Douglas, que la conexión es de ida y vuelta, es decir, todo simboliza al cuerpo y el cuerpo simboliza todo; sin embargo, el cuerpo se construye en la interacción, por lo tanto, "el cuerpo que vivimos no es nunca verdaderamente y por entero nuestro, así como tampoco es nuestra del todo la manera en la que lo vivimos" (Ibid: 195).

Entonces, el cuerpo no es el dato material de la existencia sino aquello que la posibilita, y no sólo en términos de vida, sino en todas sus dimensiones. El cuerpo es el parámetro de todas las cosas y la experiencia corporal la posibilidad de comprenderlas. La realidad del cuerpo rebasa sus propios límites orgánicos; el cuerpo es la medida de todas las cosas; así como "la imaginación presa del deseo modela el cuerpo: el cuerpo eterno del hombre... es la imaginación.” (Ibid: 186-187).

Ahora puede arribarse fácilmente a establecer que "toda realidad puede leerse partiendo de la lectura del cuerpo... recobrar el mundo del simbolismo es recobrar al cuerpo humano, auténtico, total, pleno." (Ibid:187). "Nuestro cuerpo es el órgano de lo posible y lleva también y simultáneamente el sello de lo inevitable" (Ibid:12); la actitud que tomemos frente al cuerpo refleja la actitud que elegimos, explícitamente o no, respecto de la realidad absoluta (cfr, Bernard, 1994; Pérez Cortés, 1991; Merleau-Ponty, 2000; Sartre, 1972).

Cómo, entonces, dar cuenta del cuerpo, qué se dice de él, cómo determina a vivirlo, ¿determina?, ¿a vivirlo? Qué es el cuerpo para cada quien, cómo dar respuestas sin que vuelva a realizarse o la espesa contabilidad de sus moléculas o el etéreo devenir de lo que dicen que de él levita, sin tener que fragmentarlo. Así, el cuerpo, estimable y permanente presencia, condición de posibilidad del ser. Cotidiano, mesurable, inteligible, pero incomprensible, a veces. Estadía, concreción, vínculo, modo de ser. Laberinto de creaciones. Irresistible. El cuerpo, que de tan cotidiano se torna inobservado, de tan real parece inaprensible. El cuerpo, ineludible, punto de observación, núcleo de reflexión desde el tiempo de los tiempos, y se construye en ese devenir. Siempre cabe preguntarse ¿qué es el cuerpo?, ¿cómo dar cuenta de el?; las respuestas, invariablemente, se encuentran, antagónicas, semejantes, diversas, en cada época, en cada sociedad. ¿Qué hace posible la construcción del cuerpo y, a su vez, éste qué construye?

Parto del principio de que no es posible comprender al cuerpo si al mismo tiempo no se considera al sujeto, su experiencia y el contexto que determina a ambos o, en otras palabras, la cultura en la que el sujeto vive la experiencia. Dicho de otra manera el cuerpo determina --o está determinado según el nivel de análisis o la perspectiva- al sujeto a través de la experiencia que lo moldea constantemente. Ahora bien, todo sujeto, toda experiencia está definida por marcos de referencia, por patrones, es decir, por determinantes culturales, una estructura subyacente. 
Un discurso que considero viable para dar cuenta del cuerpo, quizá no exhaustivo hasta el límite pero sí suficiente, debe revisar tres elementos fundamentales: el sujeto, la experiencia y la cultura. Mi apuesta es que el diálogo entre ellos brindará una visión amplia, si no total, al menos completa de ese mundo, tan evidente y misterioso, tan deseable y omitido, tan propio y tan ajeno; escudriñado, olvidado, cuestionado, utilizado, vivido...: el cuerpo.

$\mathrm{Y}$ amén de la fascinación y riqueza de pensar al cuerpo in abstractum, éste es bajo determinantes particulares, de hecho, una inagotable suma de ellos son los que lo construyen, algunos con más fuerza que otros. Los cuerpos siempre son en situación por lo que resulta necesario hacer una cartografía del cuerpo que permita leerlo, paulatinamente, desde sus distintos modos de ser.

Mas como me interesa el cuerpo con significación, no aquel que es visto como objeto, sino el que es vivido, percibido, interpretado, observo al cuerpo en movimiento, aquel que es, porque pretende serlo, altamente significativo; es decir, el cuerpo que danza y que con ello manifiesta una gran dedicación, una pasión que se desborda en el amaestramiento de los músculos, en la fatiga, en el control del equilibrio, en el dominio del peso ante la gravedad; y más aún porque en la danza los cuerpos además de hacer, dicen algo.

La danza es, por excelencia, el mundo propio de los cuerpos en movimiento que, a partir de una severa disciplina, son capaces de hablar, mas no el lenguaje común de toda gestualidad, sino a través de la construcción de complejos códigos -retomados, ciertamente, de la cotidianeidad pero recodificados y planteados de forma exacerbada pues la danza juega, precisamente, con la exaltación de las maneras comunes de actuar-con los que el cuerpo debe comunicarse. La danza es la combinación idónea de eso que se ha dado en llamar lo biológico, lo mental, lo perceptivo, lo sensorial, pues su existencia depende de la feliz unión de todo lo que el cuerpo es.

Por eso la danza -que como toda manifestación artística conjuga multiplicidad de saberes y es una clara exposición, sublimada, del modo de ser de la sociedad - es un buen medio para dar cuenta del cuerpo, mas como el cuerpo siempre es en situación, resulta necesario observarlo en sus distintos modos de ser y actuar; una vez más, apelar a lo que he llamado cartografia de los cuerpos en situación. Para ello he retomado el discurso religioso a partir de un paradigma en el que esta sociedad ha colocado acentos especiales en su laberíntica elaboración; es el caso de la culpa, pertinaz dogma cuyo magistral fabricante es el catolicismo, que también ha señalado sus correlatos: el pecado, la virtud y la expiación.

Como inicio de un proyecto de largo alcance, en esta ocasión, amén de haber presentado el panorama general de los estudios sobre el cuerpo, siento las bases de la forma en la que me ha sido posible leerlo, aplicación que aparece en la revisión del cuerpo en movimiento que expresa lo que por culpa se entiende en la actualidad; para ello he apelado a la danza contemporánea y al discurso teológico -principalmente aunque no solamentedel cual pretendo, amén de reconstruir los saberes en los que fue fundamentado --muchos de los cuales han sido elaborados a lo largo de las primeras etapas de construcción de la doctrina y reestructurados con el paso del tiempo-- llegar al punto nodal de la comprensión 
de cada una de las nociones centrales trabajadas para poder hacer una traducción a la forma en la que se viven en la actualidad.

Más allá del acuerdo o franca discrepancia de lo que el catolicismo construye y entiende por culpa, pecado, virtud y expiación, he decidido revisar y dar cuenta de dicho discurso, precisamente para conocer su elaboración, las bases de su efectividad y no su pertinencia. Ha sido, precisamente, la constatación del largo alcance que tiene la construcción y vivencia de la culpa lo que me ha invitado, en esta ocasión, a echar una mirada a la poco inocente relación que existe entre el sujeto, la experiencia, la cultura, la culpa, el pecado, la virtud y la expiación.

Y como también quiero -debo, deseo-- dejar que el cuerpo hable por sí mismo, presento imágenes de danza escénica que, ya he dicho, son construcciones altamente codificadas y que por eso las utilizo, es decir, porque enaltecen las formas comunes, en ocasiones imperceptibles, de las actitudes y modos que, occidentalmente, es posible reconocer como pertenecientes a una estadía, sensación, ánimo específico. Leo al cuerpo a través de su movimiento para lo que he seleccionado imágenes contemporáneas, elaboradas con la mirada y los saberes de estos días; con ello he buscado, tras comprender la centralidad de cada noción que analizo - culpa, pecado, virtud y expiación--, ver la forma en la que se activan en el presente, cómo se viven y cómo se representan de forma sublimada en los cuerpos en movimiento, cuerpos que danzan en la actualidad.

Así, entre palabras e imágenes de cuerpos bailantes, he buscado dar cuenta de ese entrañable infinito que es el cuerpo, esta vez revisado desde ciertos dogmas centrales para una dominante, expansiva y determinante religión que ha llegado a ser modo de pensar y vivir después de largos dos mil años de contundente existencia. 


\title{
La mirada
}

marco conceptual

\begin{abstract}
En algunos todo, absolutamente todo, tiene que ver con la fisiología: su cuerpo es su pensamiento, su pensamiento es su cuerpo
\end{abstract}

Cioran

El cuerpo... siempre el cuerpo, ¿qué es el cuerpo? Es el ser. Quién que sea no es cuerpo, qué puede vivirse que no sea en el cuerpo, con el cuerpo, para el cuerpo. El cuerpo... siempre el cuerpo. Mas no es, como comúnmente quiere señalarse, el vehículo terrenal de la existencia, ni la máquina portadora de la razón, ni lo material que anida a lo espiritual. El cuerpo es la única posibilidad de existencia del ser y, en esa medida, el lugar donde se inscribe la experiencia e incluso lo que posibilita vivirla, pues es también lo que permite el conocimiento y la razón y son de él los sentidos y las energías vitales.

El cuerpo es el ser, mas como decía Sartre, el ser en situación o, dicho correctamente, el cuerpo es la situación del ser, lo cual implica que la corporeidad es un factor esencial en la situación humana, menos en cuanto a los aspectos biológicos y más en lo que ha denominado como repercusión del cuerpo en la conciencia. El cuerpo condensa toda la facticidad material que acompaña a la conciencia.

Según Sartre la existencia es un hecho contingente, puesto que un hombre pudo no existir pero si existe está, entonces, en una determinada situación, ser significa estar ahí, a lo cual denomina como una necesidad ontológica. La situación en la que un hombre se encuentre, que también es contingente, es un hecho fáctico (correspondiente a la necesaria facticidad del para-sí, que se diferencia del en-sí) y es precisamente, la corporeidad la que asegura en el hombre esa facticidad del para-sí, y le permite existir en una situación específica, misma que determina un punto de vista con respecto al mundo.

La descripción fenomenológica sartreana de la corporeidad comprende tres dimensiones ontológicas: la del cuerpo como ser-para-sí, como cuerpo-para-otro y en tanto que cuerpo-para-sí conocido por el otro, cuyo principio es que la vivencia del propio cuerpo no es originaria sino consecutiva al encuentro con el otro.

La primera dimensión, el cuerpo para-sí, es una vivencia inmediata de la corporeidad, el cuerpo no como puede ser visto por otros, sino entendido como vivencia, lo cual involucra todo lo que el cuerpo es, incluidos los planos biológico, psicológico y fisiológico. Esta vivencia se entiende como una derivación del hecho de que el hombre existe como ser-en-el-mundo. Así, el cuerpo no es un cosa más entre las cosas del mundo, sino que constituye la situación de cada ser, componente esencial del para-sí. El cuerpopara-sí es una situación, por lo tanto no es algo cognoscible, sino vivible; no se conoce, se es. Es el cuerpo vivido. 
Igual sucede con los sentidos, puesto que sirven para obtener conocimiento de las cosas pero no de ellos mismos: la vista es conocimiento de los objetos visibles, pero no de ella misma. Con lo sentidos se percibe pero no son, a su vez, perceptibles a ellos mismos, son por lo tanto incognoscibles para el cuerpo-en-sí, aunque quizá se puedan conocer a partir de los objetos que ellos conocen. Lo mismo sucede con respecto a la acción, pues el cuerpo no es un instrumento que se utiliza, sino que se es. Percepción y acción son el centro de conocimiento, pero también generan un conocimiento o, mejor dicho, vivencia de sí. Entonces, el cuerpo es centro total de referencias en la medida en que aparece simultáneamente con el mundo --pues la única manera de entrar en contacto con el mundo es pertenecer al mundo--; es lo que lo hace perceptible, cognoscible, vivible. El cuerpo sintetiza los estados del ser-en-el-mundo y, en esa medida, es la condición de posibilidad de todas las facticidades del mundo (como el pertenecer a una clase social, a una nación, tener un carácter determinado y un pasado, es decir, a todo lo que Sartre denomina como facticidades) pero configura una facticidad peculiar pues no es ninguna de las otras ni la suma de todas ellas.

El cuerpo es entonces parte inalienable de la condición del ser humano que es ser en situación, situación que se vive, se existe, según una peculiar modalidad de la conciencia. La propia corporeidad forma parte de las estructuras de la autoconciencia pero de aquella que se le llama como no posicional, es decir, que el cuerpo propio no aparece, en principio, como un objeto cognoscible, sino vivible y, en esa circunstancia, medida la conciencia no cesa de tener un cuerpo.

Ahora, la segunda dimensión ontológica, la del cuerpo percibido, del cuerpo-objeto en su realidad anátomo-fisiológica, tal y como es percibido por el otro con quien se establece una relación no nada más exterior de los cuerpos, sino que el otro es aquel ante quien se existe. El cuerpo del otro es una totalidad sintética que a su vez guarda una relación significativa con los demás objetos del mundo, es un cuerpo en situación y es un cuerpo psíquico, tanto el cuerpo que se percibe como el propio que es percibido por el otro. El propio cuerpo se convierte entonces en un cuerpo objetivo que se es para el otro. Un cuerpo es siempre un cuerpo-para-sí y un cuerpo-para-otro, y se construye en ese encuentro.

Por último, la tercera dimensión ontológica del cuerpo según la cual por el hecho de que se es conocido por el otro como cuerpo, se existe para sí como tal; así, la facticidad de la existencia propia se da también como algo que está en el mundo. El cuerpo entonces no se da nada más como lo vivido, lo propio del para-sí, sino que se prolonga, se convierte en algo visto y no sólo un punto de vista. Así el propio cuerpo, al que se tiene un acceso indirecto, es dado a través de la existencia para otros y con ello una nueva estructura de la corporeidad, la que permite conocer -y no vivir como en el cuerpo-para-sí- el porte corporal, la fisonomía, etcétera. Es el cuerpo interpretado (cfr. Sartre, 1972).

Aunque de forma breve, el recapitular las nociones sartreanas de la corporeidad me permite ubicar los espacios en los que se han desarrollado los planteamientos antropológicos del cuerpo, así como aquel en el que me pretendo ubicar. Vastas son, dentro de la literatura antropológica, las descripciones que remiten al cuerpo, pero básicamente 
aquel que es visto como objeto, es decir, los usos que hay del cuerpo en una considerable variedad de sociedades. Como se "maquilla" para convertirse en pieza fundamental de la comprensión de una sociedad; sin embargo, como lo acabo de señalar, hay también otra perspectiva que si bien no es nueva ha sido poco trabajada, es la que se refiere al cuerpo ya no como instrumento para la creación de significados, sino como significando en su ser y hacer. Si el cuerpo es visto de forma estática, puede correrse el riesgo de mirársele, como ya lo hicieron los grandes anatomistas -médicos y artistas - de lejanas épocas, tan sólo como argamasa de piezas conexas.

Dentro del saber antropológico uno de los primeros que hizo énfasis en la urgente necesidad de estudiar al cuerpo fue Marcel Mauss, y no sólo en su conocido texto donde señala la obligación de dar cuenta de las técnicas corporales -apelación que, por cierto, retomó Lévi-Strauss en su afamado prólogo a la publicación de las obras de Mauss y que siguió durante años sin ser escuchada--, sino sobre todo en la elaboración de su concepto de hecho social total, esos hitos espacio temporales que determinan individuos y sociedades y que son tales debido a que involucran en su ser y haber aspectos psicofisiológicos y sociohistóricos, es decir, son posibles y adquieren su fuerza precisamente porque conjugan la totalidad del ser. Su llamado a estudiar las técnicas corporales respondía a la comprensión de los imponderables del cuerpo en todo estudio antropológico. Al mismo Durkheim no le fue ajena esa conclusión pues, con todo y el extremo valor que le otorgó a la sociedad, también señaló que todo individuo es, en principio, por su cuerpo: para distinguir un sujeto de otro, "es necesario un factor de individuación, y el cuerpo cumple ese rol" (en Le Breton, 1995:19).

Probablemente la vasta literatura antropológica en la que --más por el afán descriptivo, que por un interés específico en el cuerpo-- aparecen incontables descripciones sobre usos del cuerpo -técnicas, decoraciones, danzas...- y movido, quizá, por el entusiasmo, muy de la época, de hacer clasificaciones, Marcel Mauss sugirió la necesidad de describir las técnicas del cuerpo, entendido esto como las formas en las que los hombres, en sus respectivas y distintas sociedades, utilizan, conforme a la tradición, su propio cuerpo. Por técnica entiende no el que necesariamente se esté en contacto con algún instrumento -salvo que, siguiendo al mismo autor, se señale que el primer y más natural instrumento del hombre es su cuerpo--, sino un acto tradicional eficaz ${ }^{15}$.

${ }^{15}$ Marcel Mauss sugiere, como principios de clasificación de las técnicas corporales: 1) División de las técnicas del cuerpo entre los sexos (y no sólo en la división del trabajo entre los sexos) 2) Variaciones de las técnicas del cuerpo con la edad 3) Clasificación de las técnicas del cuerpo respecto al rendimiento y 4) Transmisión de la forma de las técnicas. Por otro lado sugiere también la enumeración biográfica de las técnicas del cuerpo cuyo ordenamiento, sugiere, consista en: 1) Técnicas del nacimiento y de la obstetricia 2) Técnicas de la infancia. Crianza y nutrición del niño 3) Técnicas de la adolescencia 4) Técnicas de la edad adulta. Dentro de esta biografia, sugiere también la revisión de aquello que compete a los momentos del día: a) técnicas del sueño b) vigilia: técnicas del reposo y c) técnicas de la actividad, del movimiento (cfr. Mauss, 1936).

A esta propuesta Ugo Volli ha añadido que la clasificación anterior debería realizarse bajo la determinante distinción de actividades y por lo tanto técnicas cotidianas y extracotidianas al igual que públicas y privadas; pero sobre todo insiste en que dichas técnicas no sean observadas como simples usos del cuerpo, sino como modos de ser del mismo y por ende de la persona y la sociedad que las practica (cfr. Volli, 2001). 
Abundan las descripciones antropológicas sobre usos del cuerpo, cada nueva etnografia las contiene de una u otra manera y en algunos casos específicos se ahonda en ello, aunque en la mayoría de las veces es para atenderlo como objeto, es decir, nuevamente en cuanto a su utilización: decoraciones -excoriaciones, perforaciones, tatuajes, pinturas--, diferenciación social y sexual por su vestimenta y ornamentación, usos cotidianos -trabajo, vida diaria--, usos extracotidianos - rituales, danzas--, etcétera. Sin embargo, en su noción de hecho social total, Marcel Mauss no apelaba tan sólo a ello, sino al vínculo entre técnica y modo de ser.

Indudablemente, "en todo momento el sujeto simboliza, a través del cuerpo (gestos, mímicas, etc.) la tonalidad de las relaciones con el mundo. En este sentido el cuerpo, en cualquier sociedad humana, está siempre significativamente presente" (Ibid:122) tal y como Bourdieu (cfr: 1991) señaló en sus observaciones de los distintos tipos de relaciones con el cuerpo y de los cuerpos. En el primer caso señala la necesidad de observar los vínculos existentes del cuerpo con los otros, con el tiempo y con el mundo donde las formas de hablar, de mantenerse, de caminar, son también las del sentir y las del pensar, donde la designación de posturas corporales es descrita con la evocación de virtudes y estados anímicos; es decir, en la compenetración existente entre cuerpo y pensamiento, vivencia del mundo y vivencia personal, comprensión de lo otro y lo propio, adjudicando el justo lugar del cuerpo pues no es un espacio en el que se inscriban datos sino en el que se viven "el cuerpo cree en lo que juega, no representa lo que juega". El punto central de esta argumentación es que "lo que se aprende por el cuerpo no es algo que se posee, como un saber que uno puede mantener delante de sí, sino algo que se es". En el segundo aspecto observa, como necesario seguimiento de lo anterior, que la gimnasia corporal se encuentra, invariablemente, cargada de significaciones y valores sociales, lo cual es una equivalencia entre el espacio físico y el espacio social en un ir y venir donde también los esquemas sociales se interponen entre el individuo y su cuerpo. Así, el manejo simbólico de la experiencia corporal manifiesta la integración de los espacios corporal, cósmico y social; tal y como se entiende al constatar que en muchos sentidos y en cada sociedad a su manera, los modos de comprender y vivir al mundo se dan a partir de los modos de comprender y vivir a lo masculino y lo femenino y viceversa.; o dicho de otro modo "las estructuras que contribuyen a la construcción del mundo de los objetos se construyen en la práctica de un mundo de objetos construidos según estas mismas estructuras".

Los anteriores ejemplos apuntan a una comprensión total del cuerpo, es decir, con todo y la persona que lo encarna -pues en verdad que son indisociables--, misma que forma parte de una sociedad determinada. Dicho de otra manera, toda comprensión del cuerpo debe, a su vez, ser una comprensión del sujeto, que se conforma a partir de sus vivencias; la experiencia o percepción de lo propio y de lo otro y la cultura, el caleidoscopio de imponderables de todo sujeto.

Estas tres dimensiones pueden ser comprendidas a partir de la distinción analítica de ellas así como de la forma en la que establecen sus vínculos. En los albores de la antropología, desde que Malinowski se enfrentó a los imponderables del trabajo de campo, 
es decir, de la observación directa de lo estudiado, fundamental para la antropología, reparaba ya en la necesidad de distinguir entre lo que es, lo que puede ser y lo que debe ser; distinción a partir de la cual es viable -o única posible - para realmente llegar a comprender tanto el funcionamiento de una sociedad -cultura--, como la funcionalidad de cada una de sus instituciones --experiencia--, al igual que el comportamiento de los miembros -sujetos-- que le dan existencia a lo anterior. Estas dimensiones tienen la capacidad de abarcar las formas de ser del humano, en tanto que consideran lo que puede ser "la concepción de ser o existir independientemente de cualquier otra cosa", como lo que es "la concepción de ser relativa -concepción de reacción- con alguna otra cosa" y lo que debe ser "la concepción de mediación, por medio de la cual entran en relación lo primero y lo segundo"; es decir, lo posible, lo real y lo necesario o el origen, el fin y el proceso, todo observado en una interdependencia que permite la comprensión de los tipos de relaciones que mantienen los elementos que conforman todo fenómeno a estudiar.

Tal distinción hace posible la comprensión de las manifestaciones de lo humano; es decir, las observación de lo posible, lo real y lo necesario permite dirimir las variadas dimensiones en las que el ser se encuentra y a partir de las cuales se manifiesta; en esa medida, hablar del cuerpo no significa mencionar sus miembros y las conexiones que entre ellos existen, sino hablar del ser, es decir, del sujeto, mismo que es a partir de la experiencia que se encuentra mediatizada por la cultura.

Vital para la existencia, la experiencia es a partir de lo cual se es lo que se es y toda experiencia se vive en el cuerpo, es una encrucijada de cuerpos, lo que determina lo demás. Así, el sujeto, además, entonces, de ser un yo-cuerpo vivo --entendido en el sentido freudiano según el cual el yo se deriva, en última instancia, de las experiencias corporales "principalmente de aquellas producidas en la superficie del cuerpo por lo que puede considerarse al yo como una proyección mental de dicha superficie (...) el Yo es, ante todo, un ser corpóreo, y no sólo un ser superficial, sino incluso la proyección de una superficie" (Freud, 1981: 2709)-- el cuerpo tiene también el apoyo --o normatividad o posibilidad de ser-- de lo social, dato a partir del cual se construye el sujeto. Ese ente "sujetado", dirá Lacan, se constituye a partir del encuentro con su propio cuerpo y los cuerpos de los demás, tal y como lo establece al esclarecer el contenido y principios de funcionamiento de los que denomina como registros:

Como alusión al exterior, y sólo alusión, el registro real tiene que ver con lo inaprensible, es decir, el mundo que es, como tal, inaccesible; lo real, que una vez que es pensado, percibido, revisado, se torna realidad. Desde este registro, todo aquello que acontezca en el mundo exterior, con o sin intervención del sujeto actante, al momento en que éste se vincula con él, lo hace necesariamente a través de los registros, lo cual implica que toda comprensión del mundo o vivencia estará permeada por los datos que indiquen cómo vivirla. Así, el registro real se activa desde el nacimiento, cuando el cuerpo se vive de forma desmembrada, y se desconocen tanto la relación del cuerpo en su conjunto como las relaciones entre movimiento e intención del mismo, al igual que la posición del propio cuerpo en un tiempo y espacio determinados. Estos hechos, que resultan incomprensibles, hacen aparecer una dimensión, que no es la propia: lo real. En este registro se exalta lo que Sartre ha llamado cuerpo vivido. 
Vinculado con el lenguaje (entendido como sistema estructurado, es decir, como la lengua saussureana), el registro imaginario es el que establece la relación entre dos yo (comprendidos como el yo-moi del francés). Es el campo de las identificaciones y de las alienaciones; se revela en la conexión dual del moi con los objetos del mundo exterior. En él se ubican el espacio, la sincronía, la metáfora, la semejanza. Este registro aparece en la confrontación con la imagen de otro cuerpo y, por ende, con el descubrimiento de la propia imagen y del propio cuerpo. En este complejo proceso, que culmina con la asimilación del cuerpo como unidad, el referente principal, siempre entendido como metáfora, es la confrontación con un otro, también entendido como unidad. Se establece como imaginario por aludir, invariablemente, a imágenes de lo real, mismas que se reconstruyen en el interior. Aquí se observa como en este registro aparece marcadamente el que Sartre ha llamado como cuerpo percibido.

Relacionado con la palabra, el registro simbólico es el que entabla una relación entre sujeto y sujeto siempre a través del muro del lenguaje. Es el campo del dominio, la normatividad de aquello que puede considerarse como verdadero. Es el ámbito del tiempo, la diacronía, la metonimia, la continuidad. Es, de hecho, el ámbito de la ley, donde la convención dota sentido, donde se unifican los dos registros anteriores. Es también el campo de los saberes culturales, el caldo de cultivo de la antropología. Este registro entra en funcionamiento por la presencia de un tercer cuerpo que encarna las dimensiones de legalidad, simbólicas. El tercer cuerpo, es, a la vez que una nueva presencia, la marca de la dimensión en la que ha de desenvolverse el sujeto, es el parámetro de los referentes que le serán, invariablemente, determinantes: la cultura en donde es contundente el cuerpo interpretado, como to ha llamado Sartre.

En el sinnúmero de acontecimientos internos y externos que van articulando al sujeto, la percepción, las emociones, las presencias y las ausencias "le van dando cuerpo" al cuerpo, con todo y sujeto; es decir, consolidan paulatinamente su ser y su saber. Así, el recorrido cognoscitivo que va del sujeto a la cultura, lo hace también a la inversa, es decir, los datos culturales determinan al sujeto, pero también la cultura es creada a partir de los datos del sujeto. La cognición, la razón, es posible a partir de metaforizaciones imaginarias cuya base es el cuerpo mismo; por lo tanto, gran cantidad de saberes han sido construidos tomando como base la corporeidad humana.

"La realidad humana (...) no se deja aprehender sino por la vía de una actividad sensorial que sirve de selector y también de puente entre la realidad psíquica y aquellos otros espacios de los que ella toma sus materiales, empezando por su propio espacio somático (el cuerpo, el cual cumple la función de) mediador y como apuesta relacional entre dos psiques y entre la psique y el mundo" (Aulagnier, 1991: 117). "La realidad es autoengendrada por la actividad sensorial" (Ibid: 121). "La actividad de las zonas sensoriales, el poderlo todo del deseo, lo que el discurso cultural enuncia sobre el cuerpo, darán lugar a tres representaciones del cuerpo y a las tres formas de conocimiento que la psique se proporciona a su respecto: tomas de conocimiento que se suceden en el tiempo, sin por ello excluirse entre sí (...) La relación de todo sujeto con ese cuerpo que lo enfrenta a su realidad más cercana, más familiar y más investida, dependerá del compromiso que haya podido anudar entre tres concepciones causales del cuerpo; las dos primeras responden a exigencias psíquicas universales y atemporales, mientras que la última será no sólo función del tiempo y del espacio cultural 
propios del sujeto, sino también la única que la psique pueda recusar, o remodificar y reinterpretar para hacerla conciliable con las otras dos. Así, pues, nuestra relación con el cuerpo, así como nuestra relación con la realidad, son función de la manera en que el sujeto oye, deforma o permanece sordo al discurso del conjunto (Ibid: 122-123).

Lo anterior se asienta en tres hipótesis: 1) "El acto que inaugura la vida psíquica plantea un estado de mismidad entre lo que adviene en una zona sensorial y lo que de ello se manifiesta en el espacio psíquico (...) 2) El yo no puede habitar ni investir un cuerpo desposeído de la historia de lo que vivió (y) 3) A partir del momento en que la psique pueda y deba pensar su cuerpo, el otro y el mundo, en términos de relaciones, comenzará ese proceso de identificación que hace que todo lugar identificatorio decida la dialéctica relacional entre dos yoes y que todo cambio en uno de los dos polos repercuta sobre el otro. A partir de este mismo momento, el cuerpo (sus cambios, su sexualidad, sus eventuales accidentes) podrá convertirse en representante del otro y en testigo de su poder para modificar la realidad" (Ibid: 134-135).

Así, un constante intercambio de datos retomados del mundo interno y externo del sujeto crean un conocimiento, consciente o no, de lo propio y del entorno. Existe entonces una construcción permanente del sujeto y la cultura donde el cuerpo es, en el primer caso, fundamental, y en el segundo, inevitable y todo ello ocurre a partir de la experiencia.

Pese a la dificultad por establecer concretamente qué es la experiencia, es dado constatar sus imponderables, así como las distintas dimensiones en las que ella aparece; así, existe un ineludible vínculo entre sujeto y experiencia el cual formará el esquema corporal, es decir, la imagen propia -así de real, así de ficticia - que se elaborará constantemente a partir de la confrontación con otros esquemas corporales, reales o ficticios. El esquema corporal y la personalidad serán dos caras de la misma moneda, uno alterará lo otro que modificará lo uno, en la permanente construcción del sujeto.

Esa perpetua confrontación, del sujeto con su cuerpo y a partir de esa unidad, con todo lo demás, serán el juego primordial de su vida y lo que le posibilitará vivirla, no sólo porque será su cuerpo el detentor de la experiencia, sino porque será a partir de su cuerpo que podrá vivirla. En el cuerpo está inserta la posibilidad de la cognición y son los ritmos corporales los que la dotan de categorías que hacen todo lo inteligible.

Los laberintos a partir de los cuales se dan el significado, la comprensión y el razonamiento humanos, son imbricados, sin embargo, el cuerpo es la base a partir de la cual se comprende y se vive lo que se comprende y se vive, puesto que la estructura de la racionalidad, difícilmente trasciende las estructuras de la experiencia corporal; es indispensable la comprensión de la corporeidad humana para alcanzar significado y racionalidad. Las categorías que posibilitan la cognición se crean con imaginación y a partir de la percepción y la capacidad motriz; estas estructuras dependen de la naturaleza del cuerpo humano. Así, toda explicación que pretenda dar cuenta del significado y la racionalidad humanas debe considerar necesariamente las estructuras corpóreas e imaginativas de la comprensión mediante las cuales se capta el mundo. E incluso, los cambios semánticos históricos se explicarán "a través de proyecciones metafóricas en el seno 
del sistema conceptual humano, motivadas por experiencias humanas comunes" (Johnson, 1991:14).

"Toda explicación adecuada del significado y la racionalidad debe asignar un papel central a las estructuras corpóreas e imaginativas de la comprensión mediante las cuales captamos nuestro mundo" (Ibid:16), por lo que es fundamental considerar las estructuras de la imaginación y la comprensión que surgen de la experiencia corpórea. Existen dos tipos de estructura imaginativa: los esquemas de las imágenes y las proyecciones metafóricas. Los esquemas de las imágenes se basan en la utilización de estructuras significativas de la experiencia, que son parte inseparable del significado y la racionalidad. Las proyecciones metafóricas aluden a la metáfora concebida como modo penetrante de la comprensión, mediante la cual se proyectan patrones de una esfera de la experiencia con el propósito de estructurar otra esfera de otro tipo. Se emplean patrones obtenidos en la experiencia física para organizar la comprensión más abstracta; esto sucede en dos sentidos: por un lado, se proyecta la experiencia para elaborar la abstracción y, por el otro, se determina la naturaleza de tales proyecciones, es decir, los tipos de conexiones que se producen entre diversas esferas. Así, la comprensión del mundo se da a partir de la experiencia, la cual "abarca todo lo que nos vuelve humanos: nuestro ser corporal, social, lingüístico e intelectual combinado en complejas interacciones que configuran nuestra comprensión del mundo" (Ibid:19). Es condición de posibilidad que los significados abstractos, la razón, se den a través de la imaginación, puesta en juego a partir de la experiencia, todo lo cual tiene una base corporal.

Entonces, el cuerpo sólo puede saberse y medirse desde la experiencia, ya sea como vivencia, percepción o interpretación del cuerpo, el propio, el ajeno y en el vínculo de ambos que es la condición del ser; la experiencia es constitutiva, aquello que hace al ser como es donde el cuerpo es el dato primordial.

Observo que son al menos tres las dimensiones fundamentales de la experiencia. Una es la que se produce en la vivencia cotidiana, que es, quizá, la más desdeñada al momento de las investigaciones, sin embargo, es en la que se va la mayor parte del tiempo y, aunque fuera tan sólo por ello, no debería omitirse. En el constante transcurrir de los minutos generalmente no sucede nada que pareciera trascendente, pero vistos en su conjunto, no pueden dejar de ser primordiales. Más atención se ha otorgado a la experiencia de momentos que resultan significativos, ahí donde algo sucede que es digno de contarse. No cabe duda que en donde se ha puesto casi toda la atención es en los momentos de experiencia liminal: aquellos que son determinantes, cambian rutas, vuelcan sentidos, institucionalizan, conforman. Uno de los más claros ejemplos son los rituales, esos hitos espacio-temporales en los que todo confluye y todo se decide.

La primera dimensión de la experiencia apela al principio de que la realidad se construye social y constantemente, en lo cotidiano, muy muy cotidiano; es decir, en el continuo devenir, sin menoscabo de la mayor o menor importancia de los hechos, sino apelando a todo aquello que fabrique un conocimiento.

En lo que se denomina como análisis fenomenológico de la experiencia cotidiana de la vida subjetiva se buscan comprender las objetivaciones de los procesos (y significados) 
subjetivos por medio de los cuales se construye el mundo intersubjetivo del sentido común donde la realidad se construye socialmente, puesto que tienen sentido las cosas que la sociedad hace que tengan sentido; la realidad de la vida cotidiana se aprehende como una realidad ordenada, se presenta ya objetivada, o sea constituida por un orden de objetos que han sido designados como objetos por la sociedad, a través de un lenguaje que es social, bajo parámetros igualmente sociales.

En este sentido, la apuesta central es instalar al yo en el aquí y en el ahora: "La realidad de la vida cotidiana se organiza alrededor del 'aquí' de mi cuerpo y el 'ahora' de mi presente. Este 'aquí y ahora' es el foco de la atención que presto a la realidad de la vida cotidiana. Lo que 'aquí y ahora' se me presenta en la vida cotidiana es lo realissimum de mi conciencia. Sin embargo, la realidad de la vida cotidiana no se agota por esas presencias inmediatas, sino que abarca fenómenos que no están presentes 'aquí y ahora'. Esto significa que yo experimento la vida cotidiana en grados diferentes de proximidad y alejamiento, tanto espacial como temporal (...) La realidad de la vida cotidiana se me presenta además como un mundo intersubjetivo, un mundo que comparto con otros. Esta intersubjetividad establece una señalada diferencia entre la vida cotidiana y otras realidades de las que tengo conciencia (...) La realidad de la vida cotidiana se da por establecida como realidad. No requiere verificaciones adicionales sobre su sola presencia y más allá de ella. Está ahí, sencillamente, como facticidad evidente de por sí e imperiosa. Sé que es real". (Berger y Luckmann, 1999: 39-41).

La realidad es algo que está dado pero que adquiere sentido por o a través de lo social, en la interacción cotidiana tanto de uno mismo con su entorno como entre los miembros de un grupo determinado. La realidad es fáctica y establece el continuum de la cotidianeidad. Lo anterior se resume en la propuesta de instalar al yo en el aquí y en el ahora, abarcando así las categorías constitutivas de tiempo y espacio en correspondencia con el yo. Aquí no huelga señalar que es en la experiencia completamente cotidiana, de cada segundo, en la que se presenta con mayor fuerza la noción sartreana de cuerpo vivido, aunque ello ocurra de forma casi del todo inconsciente, o no pensada, o no asumida, o no atendida ${ }^{16}$.

La segunda dimensión de la experiencia que considero significativa, surge del principio de que la significación se construye cotidianamente en la interacción, donde "el mundo de mi vida cotidiana no es en modo alguno mi mundo privado, sino desde el comienzo un mundo intersubjetivo, compartido con mis semejantes, experimentado e interpretado por otros; en síntesis, es un mundo común a todos nosotros (...) presupongo simplemente, que otros hombres existen también en este mundo mío y, en verdad, no sólo de manera corporal y entre otros objetos, sino más bien como dotados de una conciencia que es esencialmente igual a la mía. Así, desde el comienzo, mi mundo cotidiano es no mi mundo privado, sino más bien un mundo intersubjetivo" (Schütz, 1993: V). Aquí el acento

\footnotetext{
${ }^{16}$ Precisamente esta característica de comúnmente no hacer caso a la experiencia del cuerpo vivido provoca que cuando la corporeidad se hace constantemente presente se percate el individuo de ella. Tal es el caso de las enfermedades o el dolor, asunto al que se han abocado algunos estudios, justamente por ser uno de los momentos en los que lo no atendido requiere de toda la atención.
} 
está dado en aquella dimensión que no deja de ser cotidiana, pero que no se refiere directamente al fluir de los segundos, sino a aquellos momentos que, sin dejar de ser ordinarios, son significativos del mundo social.

Me interesan particularmente las categorías de acto, acción y conducta en las que se le da importancia a los sucesos, pero de distinta manera en aquellos que trascienden a los que no y se involucra la subjetividad e intersubjetividad en el quehacer cotidiano: "La acción (Handeln) se caracteriza, frente al acto (Handlung) y la conducta (Verhalten), por estar ligada al proyecto. La acción es inseparable del proyecto preconcebido, mientras que el acto es la acción cumplida" (Ibid: 89). "Un acto es siempre algo realizado y puede considerárselo independientemente del sujeto que actúa y de sus vivencias (...) En contraste con el acto, la acción está ligada al suceso. Mientras es acto se cumple, por así decirlo, de forma anónima, la acción constituye una serie de vivencias que se forman en la conciencia concreta e individual de algún actor, sea yo mismo u otro (...) Toda acción ocurre en el tiempo, o más precisamente en la conciencia temporal interna, en la durée. Es una realización inmanente a la duración. El acto, en cambio, es lo cumplido trascendente a la duración" (Ibid: 69). "Toda acción es una actividad espontánea orientada hacia el futuro. Esta orientación hacia el futuro no es de ninguna manera peculiar de la conducta" (Ibid: 87). "La conducta es una vivencia de asignación de significado de la conciencia (...) Una vivencia de asignación de significado debe ser un Acto del yo (...) o alguna modificación de un Acto semejante (...) los Actos de toma de actitudes (son) Actos de actividad engendradora primaria, siempre que incluyamos (...) los sentimientos y la constitución de valores mediante sentimientos, sea que esos valores se consideren como fines o como medios" (Ibid: 84). Habrá que señalar aquí que, al ser la interacción el punto central que da sentido a lo que he denominado como experiencia significativa bien puede vincularse con la noción sartreana de cuerpo percibido.

Ahora bien, la cualidad de la experiencia en las situaciones liminales, en los dramas sociales -como los ha llamado Víctor Turner--, es que se convierte en constitutiva tanto del individuo como del grupo social, atenta hacia las formas de percibir, sentir y comprender; estructura conceptos; establece dinámicas; define creencias y puede convertirse en paradigmática para un sujeto o para una cultura.

Las experiencias liminales resultan fundamentales pues ellas, como la antropología ha señalado para los rituales, se fundamentan en la legitimidad. Cuando algo, cualquier cosa se instala en el ámbito de lo ritual, lo que la sociedad vive en ello es una legitimación del suceso y de lo que dentro de él se encuentre. De aquí resulta que la veracidad otorgada a los sucesos rituales y lo que de ellos emane tienen, por ende, la capacidad de convertirse en leyes que rijan a la sociedad.

El lugar que los rituales, los dramas sociales ocupan dentro de una sociedad, es siempre el de una alta jerarquía; invariablemente se encuentran en la cúspide de la normativización de un grupo determinado, de tal suerte que sin ellos es inconcebible el ordenamiento social. Esto señala también que los agentes directamente responsables de la organización y realización de los rituales, son siempre aquellos que la sociedad -por consenso o por imposición - finalmente ha legitimado como altamente jerárquicos con la "capacidad" para tener en sus manos el destino del conjunto de sus miembros. Junto a ésta 
propuesta, incardinada completamente en el ámbito cultural, en el mundo de las interpretaciones, bien puede ubicarse la dimensión sartreana, precisamente, del cuerpo interpretado.

En su unidad, las dimensiones de la experiencia son la puesta en juego de los registros lacanianos en su conjunto, al igual que de las dimensiones sartreanas de la corporeidad; son vivencias en las que los actos, las acciones y la conducta colocan al yo en el aquí y en el ahora, bajo situaciones ordinarias, significativas o extracotidianas, sobre todo ahí donde existen comportamientos altamente marcados.

A su vez, será la sociedad la que le imponga datos a la experiencia, puesto que el sujeto se encuentra inserto en una cultura cuya normatividad es ineludible. En el vínculo existente entre el individuo, su propio cuerpo y la sociedad en la que este sujeto se desarrolla; la conformación del individuo y la de su cuerpo no están aisladas, sino que son producto de una relación intrínseca de ambos "ámbitos", donde el sujeto se inserta en una sociedad y una sociedad en el sujeto.

El sujeto se conforma, en principio, por la relación que mantiene el individuo con su cuerpo y viceversa, mediatizado por la experiencia. Es la experiencia la que conforma al sujeto y a la relación de éste con su cuerpo. Asimismo, es la experiencia la que enlaza al individuo-cuerpo, que deviene sujeto, con su comunidad. Es también a través del cuerpo que se da una relación, un diálogo con los demás individuos de la comunidad. Es en el momento de encuentro entre el individuo, su cuerpo y la comunidad, donde se constituye la identidad (cfr. Pérez Cortés, 1991).

El punto de partida para comprender lo anterior consiste en ver el cuerpo como dato biológico, pero sólo entendido a través de la experiencia, que es lo que une al individuo con su cuerpo en un marco que contempla dos horizontes. Por un lado el horizonte de la relación de sí a sí, en la que una sociedad constituye los objetos de interrogación y de saber, y de la relación de sí a sí, en la que el sujeto se constituye como pudiendo y debiendo ser pensado. $\mathrm{Al}$ considerar lo anterior, el cuerpo y el individuo quedan unidos por el proceso de la experiencia, en vez de que el cuerpo sea un simple dato biológico al que se le suman modalidades explicables por la cultura, la ética o la religión, es decir, el objeto al que se refiere la experiencia forma una unidad con el sujeto que lo reflexiona.

El análisis de las actividades corporales y la decisión con respecto al trato y definición que se le dé al propio cuerpo, tienen que ver con la identidad de sí --en tanto su propia certeza--y su horizonte de valores --en tanto son los que demarcan lo aceptable o lo inadmisible--. El resultado es una ontología histórica de las relaciones que le permite al sujeto constituirse como agente ético que lleve a comprender el presente --en tanto que diferente al pasado.

Los procesos históricos de la relación del sujeto-cuerpo con la comunidad responden a dos exigencias: una subjetivación ligada al autoconocimiento y a la búsqueda de la verdad 
acerca de uno mismo y una compleja relación con el otro(s), es decir, una búsqueda de la identidad de sí y del otro.

El cuerpo siempre está inscrito en algún tipo de experiencia, por lo tanto sólo puede hablarse de transformación y no de sustento originario, es decir, el fundamento de la experiencia no es ninguna premisa biológica o psicológica elemental. La experiencia del cuerpo es parte fundamental de la identidad del sujeto; el cuerpo lo acompaña en todas sus representaciones ideológicas, pero la identidad de sí de un sujeto no es apriorística, sino que es una identidad reflexiva debido a que se construye a través y contra la multiplicidad de determinaciones que constituyen al individuo. Por lo tanto, debido a que el cuerpo es modelado y transformado es que se convierte en una unidad con el individuo, en identidad de sí del sujeto.

Lo que se busca no es un conocimiento del cuerpo, sino de sus relaciones, pero no sus relaciones con otros cuerpos, sino la manera en que ese cuerpo es definido por el hecho de que está inscrito al interior de una experiencia: una relación del sujeto consigo mismo y con otros sujetos. El cuerpo, al formar parte de la identidad, es también un lugar en el que queda inscrita la presencia de los otros.

Es en la experiencia donde se presenta la relación del individuo con el cuerpo, y es también en la experiencia donde se presenta la relación del individuo-cuerpo, que deviene sujeto, con la comunidad; es decir, es a través del cuerpo que el sujeto establece un diálogo con los demás miembros de una comunidad. Igualmente a la inversa, en la experiencia del cuerpo se manifiesta una posición en el conjunto de las relaciones sociales: el espacio público determina una experiencia de sí del cuerpo.

La identidad depende del reconocimiento y la interiorización de sí que el sujeto logra respecto a un sistema de valores que le permiten ocupar, de manera natural, un sitio. La identidad incluye al cuerpo porque es en éste donde se inscribe ese espacio de valores bajo la forma de límites entre lo aceptable y la trasgresión, entre lo que tiene significado y lo que carece de valor. El cuerpo es también una cuestión moral porque, cuando se trata de distinguir entre lo permitido y lo prohibido, existe una intersección entre el pensamiento, el cuerpo y la vida. La conceptualización del cuerpo es incluyente y excluyente, delimita características y espacios sociales formando unidades en las que se está adentro o se está afuera. Pero estas unidades pueden ser reales, imaginarias o virtuales, pasadas o presentes y dependen de la constante elaboración de ellas por parte de los individuos, lo que garantiza su futuro. Es, pues, la experiencia, que inevitablemente se vive en el cuerpo, lo que posibilita la comprensión del mundo. Experiencia estructurada a partir de patrones culturales, aunque la cultura misma se desarrolla a partir de visiones del cuerpo.

El tan traído y llevado concepto de cultura aún puede comprenderse, de forma general, como Durkheim señala: "Desde el punto de vista de un análisis y de una interpretación científicas, se puede considerar la cultura como una cosa sui generis, como una clase de acontecimientos y de procesos que se comporta según los condicionantes de sus propios 
principios y leyes, y que, por consiguiente, sólo se puede explicar en función de sus propios elementos y procesos" (en Bauman, 2002: 253). ${ }^{17}$

Modelo estructural sistémico, "La cultura es la única faceta de la condición humana y de la vida en la cual el conocimiento de la realidad humana y el interés en el perfeccionamiento y la satisfacción propias se funden en una sola cosa. El conocimiento cultural (...) es el único conocimiento lo suficientemente audaz para ofrecer al mundo su significado en lugar de aceptar crédulamente (o pretender que se acepta) que el significado está ahí fuera, prefabricado y completo, esperando ser descubierto y aprendido" (Ibid: 341342); además, "las ramas no lingüísticas de la cultura no se agotan con ninguna descripción o modelo organizados únicamente alrededor de la función informativa. Dos funciones autónomas interfieren constantemente la una con la otra, sin que haya fenómeno cultural alguno que sea totalmente reducible a una sola función. A través de las elecciones que hace, cada sistema cultural ordena el mundo en el que viven los miembros de la comunidad en cuestión; cumple, por tanto, una función claramente informativa, es decir, disminuye la incertidumbre de la situación, así como refleja y/o modela la estructura de acción al señalar y crear la porción relevante de esa red humana de interdependencias que llamamos 'estructura social'. Pero también modela el mundo de los seres concretos, quienes, para sobrevivir, deben satisfacer sus necesidades irreductiblemente individuales". (Ibid: 222). La cultura cuestiona constantemente la sabiduría, la serenidad y la autoridad atribuidas a lo Real". (Ibid: 342).

Ajuste de cuentas con lo real, la cultura es aquello que posibilita la existencia del sujeto: le brinda parámetros con los cuales puede pensar; le otorga normas que también le permiten su libertad; estipula lineamientos que igual sirven para reconocer y romper fronteras. En la cultura se encuentra el ser, a la par que el deber y el querer. Muestras de lo anterior se encuentran con tan sólo voltear la mirada, mas existen algunas que tienen la capacidad de conjugar en su haber una multiplicidad de saberes sociales; tal es el caso de las artes.

\footnotetext{
${ }^{17}$ No cabe duda que la lucidez de este pensador continua echando frutos. Bajo sus parámetros se han bordado nuevos sentidos que no pervierten lo central de sus planteamientos, pues si a lo anterior se agregara la propuesta de Geertz, que entiende la cultura como un sistema de símbolos, o la levistraussiana, según la cual la cultura se entiende como una estructura subyacente, y a ello se sumara su propuesta para ser leída bajo la comprensión de modelos, estructuras y sistemas; el resultado, tras una mayor o menor elaboración, continuaría siendo el mismo. De cualquier manera, elaborar el concepto de cultura no es central en el desarrollo del presente texto.
} 


\section{El cuerpo}

Es obvio que dios es una solución

y que munca se encontrará otra igualmente satisfactoria

Cioran

Han de considerarse las artes, sí, pero en este trabajo en particular, aquella que es, por excelencia, cuerpo y más aún, cuerpo en movimiento, cuerpo que hace y dice a la vez: la danza, paradigma del cuerpo en movimiento que busca portar significados. Complejo hacer, la danza se ha constituido como la sublimación de la gimnasia corporal que a través de una larga trayectoria de adquisición técnica $-\mathrm{y}$ aquí vuelve a aparecer Marcel Maussentrena los cuerpos para que estos, portadores ya de un saber, puedan manifestar algo más con su movimiento.

La danza... siempre la danza... es una dimensión, casi exclusiva, en donde toda la verdad se le da al cuerpo, es éste el que sabe, es éste el que habla y el bailarín -el sujeto-es de los pocos seres que siempre viven considerando al cuerpo, pues es su modo de $\operatorname{ser}^{18}$. En todo montaje dancístico se pone en juego un saber y un hacer construido cotidianamente -la experiencia--, un juego de tiempo y espacio específico y un discurso que, si bien ha sido tomado de la cotidianeidad -la cultura--, tras nueva codificación se lleva y se presenta sublimado.

En la danza el cuerpo vivido es la inmediatez, cada segundo los músculos avisan su condición, los sentidos están exaltados; el yo, el aquí y el ahora están centrados en el movimiento, en la fuerza, en los umbrales de la kinesfera, en la vitalidad para, pese a todo o por todo, mantener el movimiento. El bailarín goza de una particular experiencia del cuerpo vivido pues las exigencias de la técnica le obligan a percatarse del funcionamiento de los miembros, los órganos, los músculos; de su capacidad y condición. El cuerpo se vive intensamente y de forma constante se tiene que apelar a sus demandas: dolor, hambre, fatiga, mismas que de ser desatendidas propiciarán el decaimiento de sus objetivos. A diferencia de la consabida poca atención que suele brindársele al cuerpo, el bailarín se vive a partir de él.

Sentido primordial en la danza es darle vida al movimiento, mas no la cotidiana gimnasia corpórea, sino el movimiento significativo, aquel en donde los actos, las acciones y la conducta están programadas para decir algo y en donde, por ende, el cuerpo percibido el propio y el otro - serán, en un camino de ida y vuelta, lo que creará y recreará sentidos, significaciones, simbolismos. Todo bailarín sabe que su desarrollo depende del cuerpo percibido -el propio y el otro-, pues en buena medida el aprendizaje está dado por la asimilación de lo percibido y por lo que el otro percibe. Tanto a nivel técnico como

\footnotetext{
${ }^{18}$ Aquí podría decirse lo mismo de los deportistas, sin embargo, lo que distingue al deporte de la danza es que ambos son un hacer, pero la danza es, además, un decir consciente.
} 
expresivo, la percepción es fundamenta. Se aprende observando al maestro -en muchas ocasiones más que de lo que éste diga-; se aprende de lo que los demás perciben de uno mismo, lo cual pasa a formar parte del cuerpo vivido.

Búsqueda constante en la danza es el crear sentidos, significaciones, mismos que, a partir de datos culturales, posibilitarán al cuerpo interpretado y harán comprensible a la danza en su conjunto. Los cuerpos en movimiento habrán dicho algo y los interpretantes articularán, según su propia experiencia, los saberes ahí construidos. Por supuesto, todo bailarín sabe que su objetivo es ser un cuerpo interpretado -de ahí la contundencia del cuerpo vivido y lo fundamental del cuerpo percibido--; esa es la apuesta: decir, dar sentidos, brindar, entregarse al movimiento para con él, o por medio de él, ser interpretado.

Dicho lo anterior resulta evidente que la danza conjuga, a su vez, las tres dimensiones de la experiencia que he señalado. En lo efimero de su especificidad, pues es algo que acontece una vez, después de lo cual ya se ha ido, en esa medida forma parte de la experiencia cotidiana, amén de que los códigos que utiliza son retomados de la misma, y porque la técnica que en ella se utiliza es algo que sólo es posible elaborar de forma cotidiana. A su vez, es significativa, pues no responde solamente a los avatares de la cotidianeidad, sino que ha sido construida ex profeso y cargada de sentidos; además, es liminal, puesto que rompe e irrumpe en los procesos cotidianos ${ }^{19}$. Toda función escénica se convierte en un acto liminal, tanto por las particularidades de presentarse en un tiempo espacio definido que no sólo aparece ajeno a la cotidianeidad, como porque la sublima; lo cotidiano se recodifica y se presenta exacerbado: un gesto que puede pasar desapercibido en la calle, es vital en el escenario.

Así, insisto, el cuerpo no es un dato biológico, sino lo que posibilita la constitución del sujeto, a partir de la experiencia, mediatizada por la cultura. Todo lo que es humano tiene, entonces, como principio y condición de posibilidad al cuerpo; tanto el cuerpo vivido, percibido, interpretado, como al cuerpo en la experiencia cotidiana, significativa y liminal.

Y la danza, esa sublimación del cuerpo con significación, aparece como uno de los lugares idóneos para leer al cuerpo, pues es todo a la vez: cuerpo vivido, percibido e interpretado que conjuga al sujeto, la experiencia cotidiana, significativa y liminal y, por ende, a la cultura.

Pensar al cuerpo es colocar en un mismo punto al sujeto cognoscente y al objeto conocido; pensar al cuerpo en escena es una de las posibilidades en occidente de ver las determinantes del cuerpo, pues las técnicas dancísticas son discursos del discurso del cuerpo a partir de las cuales se da una creación y transformación del contenido a partir de la forma. Así, busco al cuerpo en movimiento, en aquella serie de gestos con los que el cuerpo se define a sí mismo.

\footnotetext{
${ }^{19}$ Aquí no me atrevería a denominar a la danza escénica exactamente como lo que la antropología ha establecido como ritual, a menos que se reelaborara este concepto para el caso específico, asunto que no realizaré en este momento.
} 
Mas el cuerpo y la danza tienen la capacidad de significarlo todo. Cómo sería posible, entre ese todo, encontrar algunos puntos que sirvieran como guías para comprender cuáles son las modalidades expresivas del cuerpo. Resulta entonces necesario realizar una cartografia del cuerpo en diversas situaciones. Para mostrar cómo son los cuerpos en la actualidad es necesario observarlos en sus formas y determinantes, sobre todo aquellas que resultan constitutivas, como es el caso de una vivencia que se ha convertido en cardinal de la actual sociedad; para ello he elaborado una recapitulación del saber cristiano de la culpa, mismo que, leído desde la actualidad, podría permitirme observar los cuerpos que se manifiestan culpables e iniciar con ello un mapeo de los distintos modos de ser del cuerpo en situación: del ser.

Me he permitido hacer una lectura de las ilustraciones que presento a partir de las formas en las que la cultura ha señalado que se vislumbran ciertas vivencias. Utilizo imágenes de cuerpos que han sido capturados realizando representaciones escénicas altamente codificadas. Tomo las obras leyéndolas a mi antojo, pues por cierto que no necesariamente ha sido dicho que sean lo que digo que son; sin embargo, desde mi posición, es decir, como habitante de la cultura que describo, utilizo referentes que dichas obras, al dirigirse hacia la percepción, fabrican, a partir de lo que podría ser, lo que es y lo que debe ser, imágenes sensibles o ilusiones, es decir, múltiples interpretaciones. Empresa arriesgada dictaminar; válida, en cuanto me permite señalar de qué manera los cuerpos se expresan y que, en el diálogo con el receptor, pueden interpretarse libremente. Para ello hago uso de Panofsky quien elabora una hermenéutica de la obra de arte, misma que denomina como lectura iconológica y que si bien la centra en la obra plástica, también puede ser llevada a la lectura de las artes escénicas.

Panofsky señala tres niveles de observación y análisis: el primero, que comprende la revisión de las formas "puras" con especial énfasis en lo fáctico y expresivo, de tal manera en que se construya lo que denomina contenido temático primario o natural, que es el que constituye el mundo de los motivos; observar líneas, figuras, colores, su ubicación, las relaciones que establecen. En segundo lugar propone nombrar dichos motivos a partir de la convencionalidad, paso donde se construye lo que reconoce como contenido temático secundario o convencional, el cual constituye el mundo de las imágenes, historias y alegorías; nombrar las figuras, las señales, los íconos. Por último, propone la lectura de lo que denomina significado intrínseco o contenido, que constituye el mundo de los valores simbólicos; revisar los múltiples sentidos que los nombres puedan tener y los que crean en relación (cfr. Panofsky, 1972).

Es así, con esta mirada lanzada a los cuerpos en movimiento, como daré cuenta de la forma en la que la culpa, según ha sido construida por el catolicismo donde aparece, en principio, tan sólo como un discurso de complejas relaciones entre el pecado, la virtud y la expiación, en realidad se incardina en el sujeto, determina su cuerpo, modifica su experiencia y transforma al ser. 


\section{La culpa}

Inaprensible como en un principio aparece, la culpa es una vivencia fundamental --por contundente y formativa-- en la sociedad actual. Construida desde distintos discursos, la culpa es una norma o dogma que se inserta en la vida cotidiana del sujeto. De entre los saberes que se han elaborado en torno a la culpa, el que más se ha desarrollado y que emana sus afluentes a los demás, es el cristianismo, religión, o doctrina, o modo de vida --como quiera que se asuma - indispensable en la construcción del cuerpo y sus visiones en la actualidad.

Para el cristianismo, que ha desplegado un considerable saber en torno a la culpa --y sus necesarios correlatos sin los cuales no sería lo que es: el pecado, la virtud y la expiación--, la culpa es el sentimiento que se vive --porque debe vivirse-- cuando se realiza una falta, aunque no de cualquier naturaleza, sino básicamente cuando se comete algún pecado.

Cuerpo y culpa se llaman mutuamente pues las exigencias o desvíos o necesidades del primero, según el cristianismo traen, como consecuencia prácticamente ineludible, la vivencia de lo segundo. Resulta sumamente ilustrativo cómo se llega a tal confabulación pues presenta el papel y lugar que el cuerpo juega en tan expansiva y dominante religión y modo de vida, pensamiento y obra.

Según lo estipulo el cristianismo, las energías naturales de la vida del cuerpo y del espíritu son propiedad inmediata del ser humano, lo que no hace más que explicitar "el impenetrable misterio de la existencia concreta del hombre: la existencia de un ser que es a la vez corporal y espiritual, y que ha sido creado, elevado, caído y redimido" (Pieper, 2001: 189). "Dios, haciendo especial honor a aquello que se considera más bajo, ha dispuesto el cuerpo (lo ha dispuesto, lo ha ordenado, lo ha configurado, lo ha constituido) de tal forma que no haya en él disensión alguna, sino que sus miembros se ayuden unos a otros" (Ibid: 222).

Transparente, el cuerpo refleja las vicisitudes del alma "como el alma es la forma del cuerpo, salir a él y dejarse ver en él es algo que pertenece a su esencia (...); ese principio fundamental (...) implica no sólo la información del cuerpo por parte del alma, sino también una dependencia por parte del alma de ese objeto de su información que es el cuerpo (Ibid: 295). Para el cristianismo, ese pálido reflejo del alma que es el cuerpo no oculta, aunque quiera, los avatares de su interior, mismos que deben ordenarse, sobre todo ahí donde el cuerpo se impone. Mutuamente dependientes, cuerpo y alma; subordinado y subordinador; pasión y razón; muerte y eternidad.

Antes de continuar debo hacer una aclaración: la teología cristiana fundamenta muchos de sus contenidos en etéreas e inasibles categorías tales como bien, mal; verdad, mentira; realidad, falsedad; conocimiento, razón. Desde otros saberes habría gran dificultad -como diversas epistemologías lo demuestran-- en establecer de forma positiva lo que cada una de ellas quiere decir; sin embargo, esta doctrina reconoce valores y califica a cada una de ellas. Más allá de su acierto observaré, en seguida, algunos puntos esenciales para la continuidad de mi exposición. En su momento ahondaré en ciertos conceptos cuando así se requiera. 
El bien, estrechamente relacionado con la felicidad, se reconoce como el conjunto de todas aquellas cosas que la voluntad es incapaz de no querer. Dentro de la naturaleza del bien pertenece al ser el no estar limitado al propio lugar de origen, sino más bien derramarse, operar hacia afuera, comunicarse, irradiar. Cuanto más excelente es un bien, tanto más y más lejos irradia su bondad. La mejor manera de ser bueno habrá de consistir en usar la propia bondad no sólo para sí mismo, sino también para los demás (cfr. Ibid: 114-115). La realización del bien presupone el conocimiento de la realidad, que es aquello que objetivamente es, según fue creado y se puede conocer por medio de la razón o del orden de la razón la cual es concebida por Santo Tomás de Aquino ${ }^{20}$ como "el sentido de lo externo visto por nosotros, por lo que nos relacionamos con ello" (Ibid: 234).

De forma causal, el vínculo que hace indisociables a la culpa, el pecado, la virtud y la expiación, aparece difuso a la conciencia aunque sólido y contundente en su vivencia. La exorbitante presencia de la culpa se deriva del acto de cometer un pecado, lo cual es posible cuando se falta a las virtudes; sin embargo, es aún difícil establecer no la contundencia de la culpa, sino las formas en que se construye y los alcances que logra tener.

"El carácter inconcluso de toda interpretación humana de la culpa podría, no obstante, articularse en una verdad más amplia, aunque ésta, como ella misma, nunca pueda captarse positivamente y sólo puede mostrarse en una forma negativa a manera de insinuación: en una extrema experiencia interna o en datos que apenas pueden descifrarse en particular (...) El hombre, en tanto se hace culpable ante el foro de la propia conciencia y de los valores, infringe a la vez una norma puesta por dios, en lo cual consiste precisamente la esencia del pecado según la información diáfana de la tradición humana" (Pieper, 1986: 21-22).

Indisociables, las nociones de culpa y pecado inician su camino por el mismo sendero; "Nicolai Hartman define (al pecado) explícitamente, a saber: La misma culpa moral de la que habla también la ética, pero no como culpa moral, es decir, no como culpa ante el foro de la propia conciencia y de los valores, sino ante dios. Ésta es (...) la definición tradicional de pecado, que se encuentra tanto en Tomás de Aquino, como en Kant y en Kierkegaard. Tomás: El carácter de culpa del pecado procede de que éste se comete contra dios; Kant: Pecado significa la trasgresión de la ley moral como mandato divino; y Kierkegaard: La culpa humana se convierte en pecado por el hecho de que el culpable sabe que está ahí ante dios" (Ibid: 1718).

"Pecado viene de peccatum. El latín peccatum, en la época clásica, significaba falta, acción culpable, crimen, error. Peccatum viene del verbo pecco, peccare, que significa: dar un traspiés, dar un paso en falso. Peccare se emplea en latín, sobre todo, como el griego sphallomai en el sentido moral: cometer una falta o un error, equivocarse.

${ }^{20}$ Para Santo Tomás de Aquino, la razón tiene un sentido realista, no idealista; es un concepto exento de lo que comúnmente se entiende por racionalista; no tiene que ver con la razón propia de la Ilustración (cfr. Pieper, 2001: 234). 
Peccatum traduce, en latín cristiano, el griego hamartia. La palabra hamartia, en griego clásico, significa: error, falta. Deriva del verbo hamartano que significa errar el objetivo, y de ahí desviar, perderse, equivocarse de camino. En sentido figurado, equivocarse, tener una falsa opinión, cometer una falta, ceder.

(Los maestros del pensamiento bíblico entendían por pecado) aquello que es lo más grave, el crimen contra el hombre. El pecado, en su perspectiva, es lo que destruye al hombre, de la manera que sea: fisica o espiritualmente. El crimen del hombre contra el hombre, el crimen del hombre contra sí mismo, la destrucción del hombre fisicamente, y la destrucción del hombre espiritualmente, ontológicamente (...) El pecado en la perspectiva bíblica tiene un alcance, una dimensión metafisica: es el deterioro profundo del hombre que se aparta del que es el ser y la vida" (Tresmontant, 1978: 572-573).

Culpa y pecado no son nociones aleatorias para el cristianismo, por el contrario, le son centrales; así, es por la esencia pecadora del hombre que éste es tal y por ello dios envió a su mismísimo hijo a librar a la humanidad de sus pecados, a sentenciarlos como culpables ante la desobediencia y a mostrar el recto camino de las virtudes. Resulta entonces que la culpa es una vivencia interiorizada pero el pecado es una realidad, se presenta como un hecho que no necesita demostración: el pecado es un hecho y su consecuencia inmediata es la culpa.

Súbdito del alma, el cuerpo mortal es la marca del pecado y es por el cuerpo que el alma se ve, constantemente, en peligro de perderse pues en los quehaceres de la pasión, el cuerpo es siempre condición concomitante. En el cuerpo se llevan las marcas del alma "la templanza o el desorden, ambos gritan su presencia desde cualquier manifestación exterior del sujeto; se asoman a su risa, a sus ojos. Se las nota en la manera de andar o de estar sentado (Ibid: 295).

Ilustración: La culpa

(Intérprete: Kazuo Ono)

Una figura humana masculina casi desnuda, tan sólo en calzoncillos, solitaria, en penumbras, casi de pie, con un pedazo de tela que yace a sus pies, mismos que se encuentran rotados hacia adentro y bien asentados en el piso, toda la planta y cada uno de los dedos se apoyan firmemente. Los tendones que articulan los dedos responden a la tensión generada por una breve flexión en los tobillos, provocada por el acentuado pliegue de las rodillas. Dada la postura del cuerpo, el principal sostén se ubica en los muslos; las piernas se encajan en la cadera, un tanto desviada hacia el frente, que es la que mantiene el equilibrio al constituirse como el centro de la colocación. La fuerza del abdomen hace posible que tal postura se sostenga sobre todo al sumar la proyección de la cabeza hacia atrás. El delgado torso devela las costillas, las clavículas y los huesos de los hombros, mismos que están forzados hacia abajo incrementando así la tensión de los músculos y arterias del cuello, lo que provoca que la traquea resalte. Los brazos, plegados con fuerza al torso, se flexionan a la altura de los codos y llevan a las manos a juntarse entre sí con una torsión en las muñecas que proyecta los dedos hacia el cuerpo. La delgadez y tensión de las manos delata a los tendones que van hacia las falanges. En los dedos hay esfuerzo evidente. El rostro se dirige hacia arriba, la boca está semiabierta lo que permite que se vislumbre la fila dental superior. La mueca provoca una depresión cerca de la mejilla derecha, en la misma aparece una 

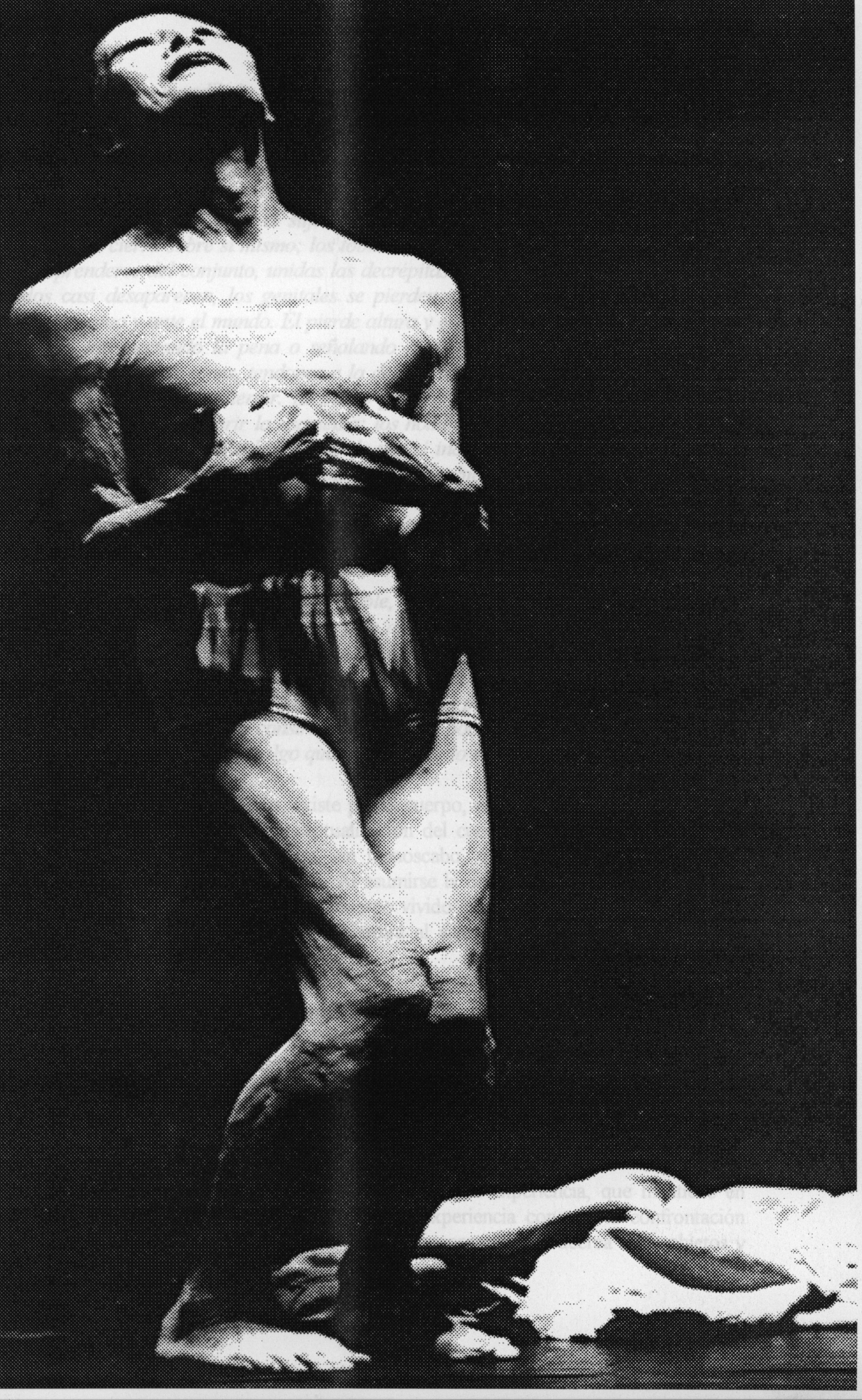
arruga recta que va de la mandibula hasta el pómulo. Se observan las cavidades nasales, los pómulos resaltados, los ojos abiertos y la frente despejada. En todo el cuerpo la piel luce vieja, reseca, decrépita quizá, de forma acentuada en las pantorrillas, las rodillas, los bíceps, el cuello y las sienes; las tetillas lucen magras, agostadas.

Algún peso se revierte sobre el sujeto: es un cuerpo que no se mantiene del todo erguido, sino que se cierra sobre si mismo; los tobillos se articulan inestables, las pantorrillas parecieran desprenderse del conjunto, unidas las decrépitas y dobladas rodillas, los músculos de los muslos casi desaparecen, los genitales se pierden en el contrito cuerpo que parece clausurarse a sí mismo y ante el mundo. Él pierde altura y estabilidad. Las manos y los pies se cierran sobre sí, introyectando la pena o señalando al culpable. Conformación de muñón, frágiles -vidriosas - articulaciones, tendones a la deriva, las manos son, en complicidad con el rostro, la huella central del estertor. El pecho pierde fuerza y gana tensión; la piel, en detrimento, casi no alcanza a cubrir la osamenta; los hombros caidos incrementan el avance de la tensión que sube con fuerza a la cabeza, de por sí inclinada hacia arriba, en un gesto doloroso, suplicante, agónico, con un rigor mortuorio que bien puede reconocerse como de súplica o de dolor: el peso de la culpa. La culpa carcome al alma y le roba fuerza al cuerpo, los músculos se vencen, se tornan lánguidos y con ellos la piel, ajada, enfatiza el proceso de descomposición, siempre doloroso.

Una vez que se ha asumido como culpable, el cuerpo se trastorna, tiene algo que ocultar y se oculta, marcado por el dolor que pide alivio a la pena y perdón. Las formas se constriñen, sufre la piel, la mirada se pierde, suplica o se esconde; más aún cuando se reconoce que el cuerpo es como es por las faltas cometidas, desde el pecado original hasta las diáfanas de la cotidianeidad. La culpa, en tanto que estado pues no es entendida como acto sino como modo de ser del hombre, constriñe al mismo y por ende a su cuerpo, que lo vive estigmatizado y del que siempre habrá algo que negar o, por lo menos, ocultar.

La culpa, proveniente del pecado, existe por el cuerpo, es decir, el pecado tiene una de sus más profundas raíces tanto en la conceptualización del cuerpo como en los avatares del mismo, de tal suerte que puede aseverarse, sin menoscabo, que si hay cuerpo, hay culpa; simple y llanamente son, así dicho, sinónimos. Al asumirse la corporeidad como marca de una falta, el símbolo del pecado, se propicia que el cuerpo vivido esté sujetado a las condicionantes del cuerpo interpretado: la experiencia que construirá al sujeto tendrá siempre la marca del pecado y, por ende, de la culpa.

La culpa, en tanto que vivencia engendrada, cualifica al sujeto como ser culpable. Interiorizada, la culpa se convierte en constitutiva del sujeto; ese ente que, como señala Lacan, se vive sujetado a la falta y vive, desesperadamente quizá, no sólo en la permanente búsqueda del otro, sino en el constante deseo de ser el deseo del otro. Un otro que igual se vive y que como todos los demás abigarra de datos, estigmas y verdades culturales su marcha y su objetivo.

En tal camino se vive cotidianamente y a través de la experiencia, que mantiene en marcha los tres registros conformadores del sujeto; la experiencia constata la confrontación con el mundo y sus objetos, es decir, de aquello que es inaprensible; se acerca a los objetos y 
los nombra y a los sujetos, a los que no es posible llegar más que a través del muro del lenguaje.

$\mathrm{Si}$, como sugiere Lacan, la experiencia es la que marca el funcionamiento de los registros conformadores del sujeto; y si, como sugiere Aulagnier, la experiencia se vive primero y directamente en el cuerpo y es a través de la percepción que existe un acercamiento al mundo; y si, como sugiere Johnson, la cognición es posible a partir de metaforizaciones de la experiencia corporal; y si, como propone el cristianismo, la culpa es una vivencia que anida en la profundidad del ser que ha pecado, entonces resulta evidente que una vez que se ha asumido un ser como culpable, ésta vivencia será un factor que medie la experiencia y comprensión de la cotidianeidad del sujeto. Así dicho, la culpa quedará encarnada en el sujeto y permeará su experiencia cotidiana.

Determinantemente asentado, todo aquel que retome el cristianismo para su vida, asume al mismo tiempo su calidad de pecador, deudor, culpable aquí y ahora, a la vez que una visión particular del cuerpo al que deberá mantener, invariablemente, bajo vigilancia pues de lo contrario su conducta podrá con toda facilidad cometer algún acto pecador que condenará sus acciones indefectiblemente.

Para realizar una delimitación del concepto de pecado deben observarse dos campos de significación: uno general, en donde pecado alude al mal, a lo privado de bien, a lo malo; y otro que compete al ámbito de lo particular en el cual pecado alude a la acción defectuosa, a la falta humana, al mal causado por acción u omisión. Asimismo se tendrá que aclarar que todo pecado es una falta, pero que no toda falta es un pecado pues el pecado descansa siempre, pero no solamente, en una opinión errónea sobre la esencia de lo real.

Igualmente se deberá entender que no sólo la acción consumada constituye pecado, sino también la complacencia voluntaria en la representación del deleite que acompaña a esa acción, pues no es imaginable tal complacencia sin la aceptación del hecho exterior. Por consiguiente, todo lo que procede de esa complacencia voluntaria también es pecado.

Se han señalado cinco puntos clave para la comprensión del pecado:

1) El pecado no es simplemente un defecto, es un acto, una acción humana; consiste esencialmente en un hacer y, por tanto, primariamente y a diferencia de la culpa, no es un estado.

2) El pecado es una perturbación de la ordenación al fin, es a la vez, y quizá en primer lugar, infracción de una norma de conducta que generalmente tiene relación con los avatares de un cuerpo desordenado.

3) El hombre se encuentra predispuesto al pecado.

4) Ningún otro defecto que la falta moral, es decir, el pecado, puede hacer culpable al hombre. Sólo el pecado perturba o corrompe el movimiento interno del hombre hacia su fin más propio. 
5) Es moral en sentido pleno aquel acto que se halla por completo en nuestro poder. Es decir, pertenece también al concepto de falta moral, o sea, de pecado, el que haya que responder de ella y sea imputable. Si no se diera esta libertad de decisión, en virtud de la cual podemos comportarnos de una manera o de otra, si no hubiera ninguna acción fallida, una acción que está en nuestras manos, que nosotros queremos, que brota de nosotros; entonces no habría ni culpa ni pecado en sentido estricto (cfr. Pieper, 1986: 39-40).

Sustancial para la comprensión del pecado y una de las preocupaciones del cristianismo, sobre todo de sus grandes pensadores es la cuestión del orden; el pecado, como se verá con mayor claridad cuando aborde el tema de las virtudes, es una falta de orden. "no sólo el pecado mismo se califica de acción contraria al orden; también sobre el alma decimos que se desordena por el pecado; y así la esencia del pecado se cifra en que el alma pierde su orden" (Ibid: 43).

El pecado incluye la intención consciente, el algo antirracional o contra la razón --por razón se entiende la receptividad para la realidad, la fuerza para captar la verdad, la sabida y la creída-- "un actus contra rationem, o sea, una especie de locura, y no algo enfermizo, no precisamente algo que se deba a la incapacidad de responsabilidad, sino un acto de irracionalidad cometido con plena inteligencia y responsabilidad (y por ello podemos decir: loco). Espontáneamente se insinúa el concepto de ofuscación, que no ha de entenderse en el sentido de ceguera, no ver, ausencia de conocimiento, sino que contiene a la vez un factor de imputabilidad y de culpa" (Ibid: 51-52).

"Existe una pugna entre pecado y conocimiento. Y conocimiento significa esclarecimiento de la realidad, verdad, luz. La acción humana es buena en virtud de su adecuación con la realidad, es decir, por el hecho de que se deduce del conocimiento de la realidad. Y el pecado es contradicción a lo que el hombre sabe y ve; es negación de la luz de la razón. Lo que va contra esta luz, es malo para el hombre y contrario a su naturaleza" (Ibid: 52). El principio rector de las afirmaciones precedentes consiste en que "Todas las leyes y reglas morales pueden reducirse a una: a la verdad" (Ibid: 53).

\section{Ilustración: Pecado}

\section{(Intérprete: Marco Antonio Silva)}

Cuerpo masculino con ropajes que permiten adivinar su anatomía. Pie, pantorrilla y rodilla izquierda dan apoyo a la pierna flexionada a noventa grados. En posición triangular con respecto al apoyo, la pierna derecha sólo tiene el metatarso en el piso. La pelvis, en la que se adivinan los genitales, responde a la posición de las piernas e intenta equilibrar al torso que en profundo arco cae hasta atrás. Pecho, clavículas, traquea, nervios, tendones, arterias se tensan en el esfuerzo. La cabeza prolonga el movimiento. El brazo izquierdo, con la palma firmemente plantada en el suelo, en esfuerzo total, sostienen al cuerpo y evitan la caida. El brazo derecho, que responde a la curvatura del torso se retracta para flexionarse y llevar la mano, tensa, decidida, abierta, al rostro; lo cubre, lo evita. Imposibilita ver y que lo vean.

Ninguna tensión en el cuerpo es arbitraria, ningún esfuerzo se encamina hacia nada; movilidad de nervios, músculos y tendones es movilidad del ser; la experiencia lo 


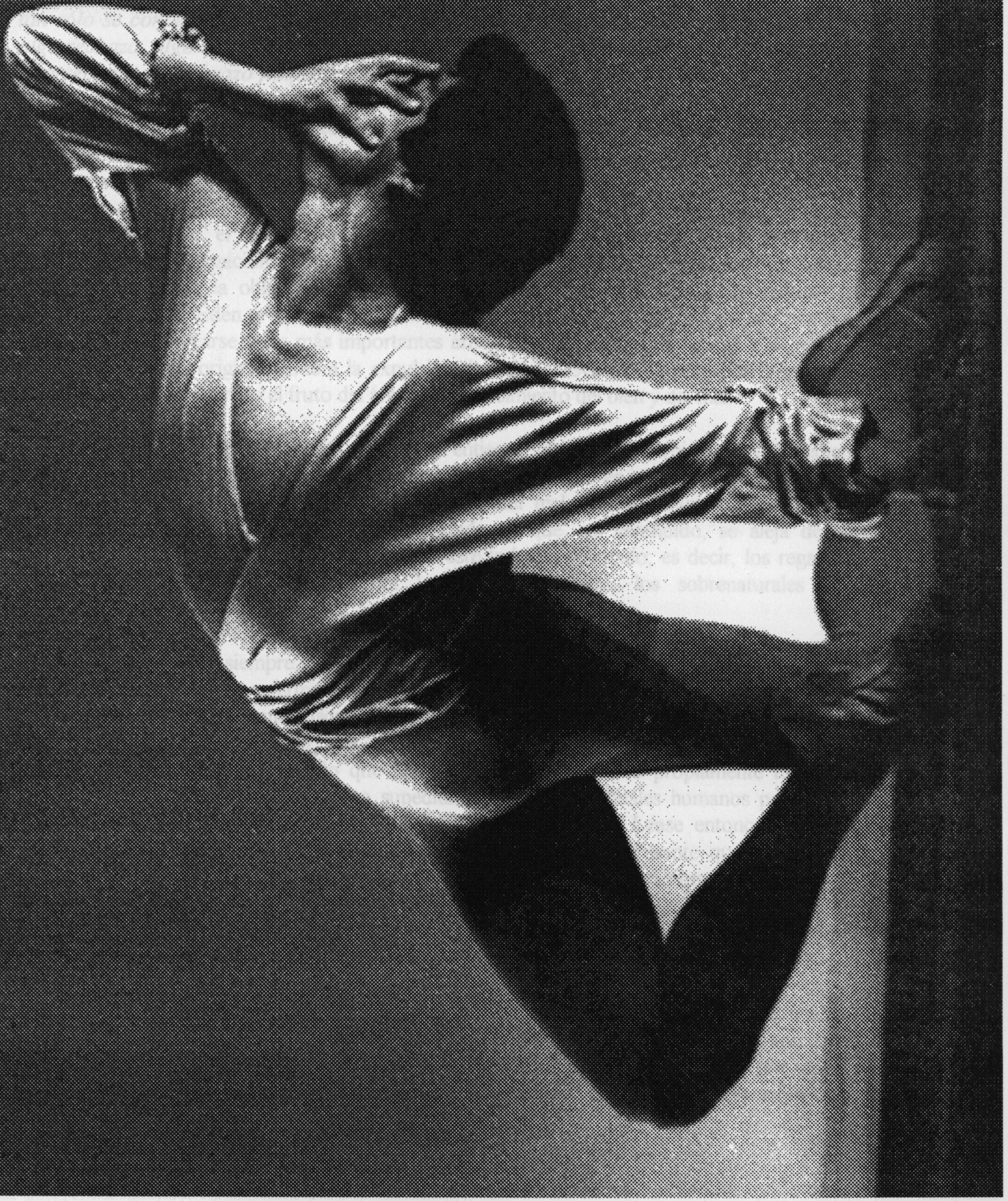


sabe, el cuerpo vibra por algo, ante algo; los observadores apelan a sus propios datos para descubrir qué acontece. Velar el rostro implica negación de sí o hacia lo otro; la percepción se altera, el cuerpo no quiere ser interpretado en su vivencia. Es un hombre que se tensa, se arquea, se cubre y apenas se sostiene en intrépida postura que se muestra y se rechaza. Arrepentimiento, dolor, pena; una marca sin duda; algo que no quiere ver $n i$ desea ser visto. Se tuerce en el dolor pero no lo afronta, el cuerpo no tiene frente ni tras, tan sólo se concentra en la negación. Parece pesadilla pero es su realidad; algo adeuda, algo rechaza, algo esconde. Una falta le pesa, un pecado le atormenta; el cuerpo lo sabe y se arrepiente. Si el brazo flaquea, el hombre cae.

Sin embargo, el concepto de pecado abarca distintas modalidades. El primero y fundamental, que además adquiere el estatus de doctrina, es el pecado original a raíz del cual los hombres se convierten en tales y por ende en pecadores.

Bíblicamente, el creador colocó a los primeros hombres en el paraíso, en un estado de gracia, bajo una obligación y un mandato: el estado de gracia se define como de santidad, justicia e inocencia; la obligación consistía en el trabajo que el hombre debía realizar para cuidar el jardín del Edén, y el mandato era la obediencia al creador, sobre todo en cuanto a la prohibición de acercarse a los más importantes árboles del paraíso: el de la vida y el del bien y del mal. El pecado original alude a la expulsión de Adán y Eva del paraíso, por haber faltado al mandato al haber comido el fruto del árbol del conocimiento del bien y del mal.

Teológicamente, el pecado original se entiende como la soberbia y la desobediencia del primer hombre al intentar acceder a un conocimiento que es propio de dios. Cuando el hombre osa acercarse al conocimiento del bien y del mal, atenta contra la supremacía del creador y desobedece su mandato; en la medida en que, así entendido, se aleja de dios, también lo hace de algunos de los bienes que éste le había otorgado; es decir, los regalos del paraíso, entre los que se encuentran los bienes naturales, los sobrenaturales y los pretenaturales.

Perdidos para siempre, los bienes pretenaturales consistían en la posibilidad de vivir sin fatiga, ni dolor, ni enfermedad, pero aluden principalmente a la inmortalidad y a la integridad o ausencia de concupiscencia. De este modo queda establecido que el hombre es tal en la medida en que es pecador; una falta lo condena a ser lo que es: un ser mortal. En una lectura casi evidente, todo aquello que aparece como mortal es lo propiamente terrenal del hombre y en esa medida se encuentra supeditado, es decir, los males humanos provienen de faltas cuyo origen o actualización se encuentran en lo material. Léase entonces el estigma hacia el cuerpo que se encuentra desde los orígenes. Resulta interesante que desde aquí la noción de vida se conecta estrechamente con la de obediencia, mientras que la idea de muerte se emparenta con la de castigo; es decir, la muerte y el pecado se relacionan mutuamente, la muerte es consecuencia del pecado; el hombre, si no hubiera pecado, no estaría sometido a la muerte corporal.

"Nuestra muerte corporal es fruto del pecado, si no necesariamente en sí misma en cuanto fenómeno biológico, sí en cuanto es la muerte humana, de la que somos conscientes y que experimentamos como una agresión a nuestro ser más íntimo. No se trata, por tanto, de pensar en una concepción meramente espiritual de las consecuencias del pecado como muerte 
del alma, sino del modo concreto como la muerte corporal, en la manera como ésta se vive y se entiende". (Ladaria, 2001: 46-47).

Eternamente mortales: lo propio de la condición humana proviene de la falta y el hombre ha de vivir como perpetuamente pecador, pues también ha perdido la integridad, es decir, la falta de concupiscencia: "La concupiscencia es la manifestación de la fuerza del pecado que domina al hombre y ejerce su poder sobre él (...); la ley (de la carne) es la que despierta el deseo desordenado, o mejor, de la que se sirve el pecado para estimularlo (...) La concupiscencia proviene del pecado e inclina a él, aunque no puede ser llamada en sí misma pecado (...) En este sentido, la concupiscencia es algo con lo que el hombre (...) ha de contar durante toda su vida. La concupiscencia se ha identificado a veces con las tendencias inferiores del hombre, el cuerpo considerado como fuente del pecado en cuanto se rebela contra el alma o parte superior que ha de gobernar el todo (...) hay que identificar con (la concupiscencia) las tendencias desordenadas a causa del pecado, del poder del mal, que afectan a todo el hombre y no sólo a lo carnal o lo material como parte inferior, aunque es evidente que el desorden que sufre el ser humano se manifiesta también en este aspecto o dimensión de su ser.

"El punto de partida es que la concupiscencia no es sólo el deseo del mal, sino más bien todo acto apetitivo, indeliberado, que precede a la decisión libre del hombre; esta decisión es la posición, ya refleja, que el hombre adopta frente a la apetencia espontánea de un bien u otro. Esta inclinación espontánea es la base sobre la que la persona adopta su decisión libre: la libertad humana, en virtud de nuestra constitución psicofísica, no se ejerce desde el vacío. La decisión se toma sobre la base de lo que en nosotros es naturaleza, como contrapuesto a lo que nos define como personas. Pero precisamente este aspecto de naturaleza de nuestro ser no es del todo transparente, ni siquiera para nosotros mismos; por ello nuestra decisión libre no lo puede penetrar de modo total. Por esta razón, el hombre, al optar en libertad, no se determina enteramente; quedan zonas o aspectos de nuestro ser que no están sometidos al control de la libertad. Así nuestra decisión por el bien no es completa. Pero esta condición, si impide que nuestra opción por el bien sea total, hace también menos grave una decisión por el mal, porque tampoco ésta abarca nuestro ser en todos sus estratos. La concupiscencia sería en sí misma, por tanto, algo neutral". (Ladaria, 2001: 48-49). Neutral pero peligrosa en sus consecuencias pues al ser la concupiscencia la división interna del hombre, le impide actuar de forma ordenada y con claridad sobre sí mismo y su entorno.

A su vez, los bienes sobrenaturales son posibles por la benevolencia divina, es decir, si bien se han perdido como cualidades intrínsecas del ser, son accesibles para él mismo; estos son, en sentido estricto: la amistad con dios y la gracia, la llamada a la divinización y la visión beatífica. Una ardua labor sobre sí mismo posibilitará acercarse, cada vez más, a los bienes sobrenaturales.

Propios del hombre, los bienes naturales son los únicos que ha conservado sustancialmente íntegros, puesto que le son intrínsecos, aunque se encuentran, permanentemente, afectados por el pecado.

Para la teología cristiana el pecado original es lo que hace a los hombres como son, es decir, pecadores. Puede considerarse como el núcleo del pecado, es decir, el primer pecado es 
paradigmático ya que muestra lo que en el fondo todo pecado es. En el pecado original el hombre se aleja de dios y, por lo tanto de los bienes por él otorgados; así, las consecuencias del pecado no son arbitrarias ni exteriores al mismo; por el contrario, están intrínsecamente relacionadas con él.

Nombrado con una especial cualificación, el pecado original "es el comienzo de una historia que está marcada y en cierto modo determinada por él. En efecto, después del primer pecado, con la consiguiente pérdida de los bienes del paraíso, continua la historia de pecado y de muerte (...) En este sentido se puede hablar de culpa o de pecado que procede del origen y que de algún modo es hereditario" (Ibid: 62-63). "El pecado de Adán está en cada uno de nosotros como propio, además, Adán nos ha dejado una herencia, la fuerza del pecado que nos domina; como consecuencia de ella, todos cometemos pecados personales" (Ibid: 80).

A partir del pecado original "arranca la historia de pecado (...) no sólo ni primariamente a causa de la imputación a todos de este primer pecado, sino sobre todo por la presencia en el mundo de la fuerza del mal que a todos avasalla; el pecado personal puede considerarse como la inserción, libremente ratificada, en esta corriente de pecado que Adán ha iniciado (y) que da lugar a las estructuras de pecado" (Ibid: 114). La noción de pecado aplicada al pecado original y a los pecados personales es análoga y no unívoca en la medida en que el pecado original es originante, puesto que es la base de la unidad de la especie humana. El pecado original se considera como una falta "arquetípica" en la que aparece la naturaleza de todo pecado.

Pecaminoso en extremo, el libre albedrío o la libertad de tomar decisiones es lo que hace a Adán culpable, dícese que es la "decisión por el absoluto amor propio, o sea, por la libertad en este sentido asimismo absoluto, es decir, desligada de toda proporción con la realidad, constituye el pecado original, el primero que se haya cometido jamás y (...) el origen permanente de toda culpa concreta" (Pieper, 1986: 77). Aunque bien se insiste en que "a partir de la cualidad positiva de la libertad no puede explicarse lo negativo de la culpa y el pecado" (Ibid: 94).

"El que peca desde una postura de desorden arraigado tiene perfecta conciencia y dirige su voluntad al pecado (...) La verdadera maldad está en pecar con disposición básica desordenada de la voluntad; pecar, en cambio, por una arremetida de la pasión es una debilidad. El hombre que quiere pero no acierta a dominarse, no es deshonesto aunque cometa deshonestidades" (Pieper, 2001:245) aunque todo pecador es, de forma primaria y esencial, imprudente.

"Estaban ambos desnudos, el hombre y su mujer, y no se avergonzaban (Génesis, 2:25). Mientras Adán y Eva fueron inocentes, ignoraron completamente su desnudez. Sólo su culpa les llamó la atención sobre aquella, y dios supo inmediatamente, tan pronto como Adán confesó su temor a su desnudez, que habían desobedecido" (Graham Cole, 1964: 319).

La relación entre pecado original y pecados es indirecta ya que el eslabón entre ellos, que es la concupiscencia, no es en sí misma un pecado. Queda claro entonces que en el cristianismo, si bien se distingue entre el pecado original, el cual se transmite por generación y 
los pecados personales, los cuales están en manos de cada quien, es a partir del primero que los demás son posibles.

El cristianismo y por ende todo cristiano, observa la realización de pecados propios y ajenos ya que en ambas dimensiones se reduce la capacidad de elección entre el bien y el mal; el pecado tiene consecuencias y dimensiones sociales, pues es "ruptura con dios, ruptura con la comunidad y destrucción de la armonía que en ella reina (...) Al pecado sigue la culpa, aquella situación en la que el pecador se coloca y a la que inevitablemente arrastra a otros, de modo particular, aunque no único, a los descendientes (...) Los diferentes vínculos de solidaridad entre los hombres están en la base de la responsabilidad colectiva por el pecado y la culpa de cada uno. No es extraño, desde estos presupuestos, que por el pecado de uno sufran todos castigo, ya que toda la comunidad tiene la responsabilidad de excluir de su seno al pecador y así restablecer la paz con dios (existe entonces una) responsabilidad y castigo colectivos por los pecados e injusticias" (Ladaria, 2001:59). El pecado humano no afecta solamente a aquel que lo comete.

De entre los pecados que se realizan de forma personal se encuentran los veniales y los capitales o mortales, los primeros son todos aquellos que se cometen cotidianamente y que no llegan a ser mortales pero que no por ello no lastiman al cuerpo, y lo hacen en dos sentidos, por un lado en el acto mismo, la falta cometida y, por otro, en que son la confirmación de la esencia pecadora del hombre.

Denominados así por ser cabeza de otros, es decir, que tienen la capacidad de engendrar más pecados, los pecados mortales son las faltas que nunca tendrán perdón. La raíz común de los pecados, en particular los mortales es el egoísmo, que antepone los propios gustos y caprichos a la ley de dios; en el amor propio se encuentra el mayor riesgo pues un exceso del mismo puede convertirse en enemistad con dios y caer así en pecado mortal. El concepto radical de pecado se realiza sólo en el pecado mortal; los pecados mortales son así, signos, entendidos estos como manifestación y encubrimiento del alma humana que se transforma por el dolor de saberse desviada de su camino.

\section{Ilustración: Pecado mortal}

(The struggle)

Un torbellino de texturas, claroscuros, deviene figura de mujer. Casi de espaldas, inicia un perfil de precario equilibrio que se pierde en la turbulencia del remolino que no se sabe si arremete contra el cuerpo o surge de él. Tensiones encontradas, poder omnipresente. Las manos, un tanto débiles, buscan asidero o detienen la vorágine; los brazos, con cansado esfuerzo, sustentan la acción de las manos; la espalda, solidaria con el esfuerzo y la intención, sostiene a los brazos; el seno que se vislumbra entre los claroscuros del dorsal derecho, responde a la obligada curvatura del torso que se afana en adquirir la posición necesaria para sostener la adversa situación; los glúteos se redondean en la acción; la cadera un tanto lanzada hacia la derecha, busca centro ante el desequilibrio del cuerpo que ha perdido el apoyo de la pierna izquierda, misma que se lanza hacia el frente como jalada por un impulso, la otra apenas sostiene el conjunto. Una sola energía recorre la silueta, cargada de erotismo, y eslabona los esfuerzos que se despliegan ante el impacto. La cabeza se contrae, ni enfrenta, ni apoya, derrotada ante la 


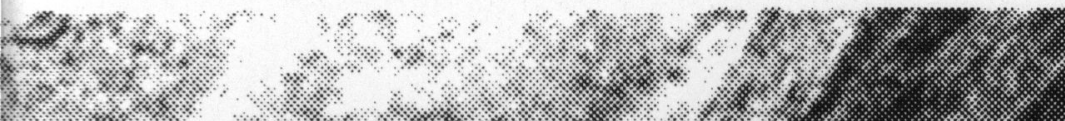

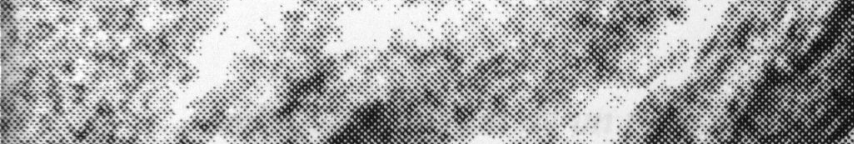

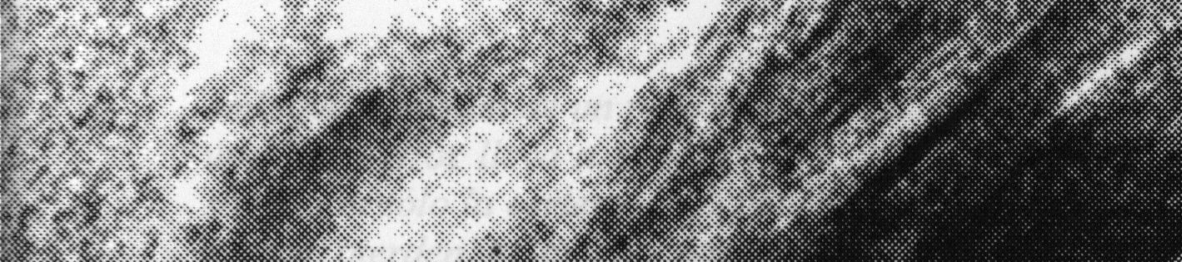

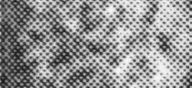

3

4

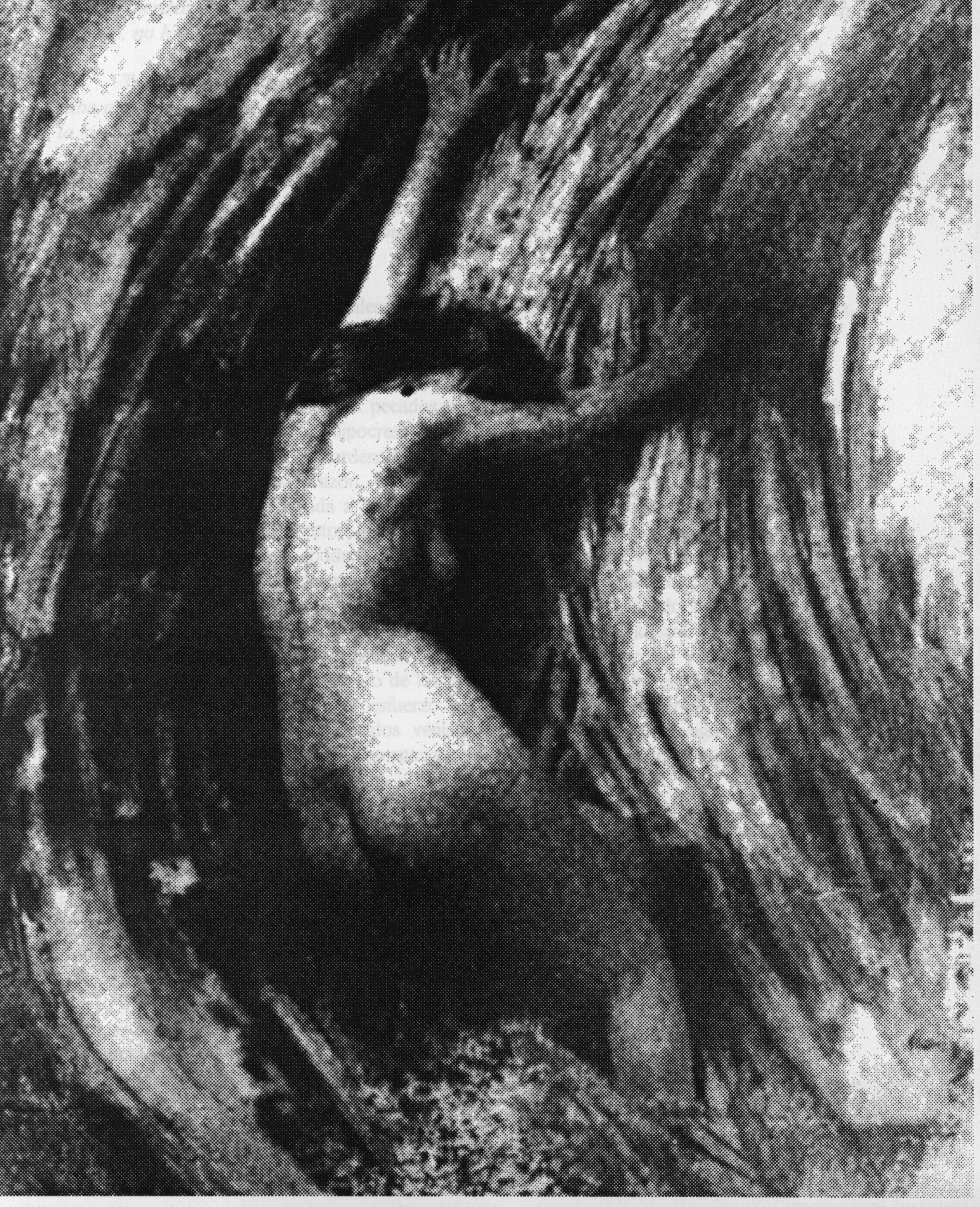


ambigua opresión de un peso difícilmente soportable. Sólo una marca fatal derrumba, sólo una falta atroz lleva a la tempestad, sólo la gravedad del error irreparable es tormenta, sólo y tan sólo la certeza de la pérdida total, de la imposibilidad del perdón ante el pecado mortal pierden al cuerpo en marejadas de desorden infinito. No hay reposo, no hay retorno, no hay salida. Mujer acosada que va cayendo, cae y caerá.

Torbellino que arremete contra el ser, todo aquel que ha cometido pecado mortal sabe que habrá de caer pues no hay retorno posible, una vez cometido el acto transgresor lo siguiente, tarde o temprano, es el purgatorio. Lo propio del pecado mortal es el ser un acto que engendra imposibilidad de salida, es la irremediable caida; turbulencia, abismo, debilidad, destemplanza. La acción iniciada en el interior del hombre arremete después contra él desde todos los rincones, como remolino que no hay manera de evitar. Los pecados mortales redundan en la turbulencia del cuerpo y el alma y las luces y los caminos de la impostergable caida.

Siete son los pecados capitales que de forma breve, como lo hace la doctrina cristiana, se definen de la siguiente manera:

Soberbia: amor desordenado de sí mismo, induce a la persona a estimarse más de lo que en realidad es. Algunos de los pecados veniales que de ella se derivan son: presunción, vanagloria, ambición, vanidad, hipocresía, desobediencia, jactancia, pertinacia, ostentación y altanería. Avaricia: deseo desordenado de poseer bienes o riquezas. Algunos pecados derivados son: dureza de corazón, injusticia violenta, fraude, perjurio, traición y tacañería. Lujuria: inclinación desordenada a los placeres sexuales. Pecados que de ella se derivan son: fornicación, adulterio, incesto, prostitución, homosexualidad, zoofilia, masturbación, onanismo, estupro, rapto y sodomía. Ira: apetito desordenado de venganza. Algunos de los pecados veniales que se desprenden de la ira son: odio, maldición, venganza, furor, contumelia, blasfemia, rencor e impaciencia. Gula: apetito desordenado de comer y beber. Envidia: tendencia a entristecerse del bien ajeno, en cuanto rebaja nuestra gloria y excelencia. Pecados veniales que de ella se derivan son: tristeza, odio, detracción y calumnia. Pereza: tendencia a la ociosidad o al descuido de los propios deberes; es también un debilitamiento de la voluntad que rechaza cualquier esfuerzo y trabajo que son necesarios para cumplir las propias obligaciones. Algunos pecados veniales que se derivan son: vagancia, indolencia, negligencia, pusilanimidad, tedio, inconstancia, asedia y divagación de la mente. (cfr. Baduí Dergal, 2001).

Pecado original, pecados mortales, veniales... "En todo caso permanece en pie que, visto desde dios, sólo puede haber algo así como juicio condenatorio, penitencia, retribución, castigo en un sentido absoluto, si el pecado es realmente lo que el hombre a través de su historia nunca ha podido olvidar o negar en forma definitiva: una falta libre, cometida con intención consciente, contra el verdadero sentido de la propia existencia, contra el orden, contra la naturaleza, contra toda razón y, en el fondo, contra dios mismo" (Pieper, 1986: 91).

Tomás de Aquino señala que "malum, peccatumm, culpa en cada caso se comportan entre sí como lo más universal con lo menos general (...) en la forma de hablar de los teólogos peccatum y culpa se entienden como equivalentes en su significación" (Ibid: 2526). Se ha señalado más aún pues se afirma que el pecado es el verdadero carácter de la 
culpa humana; sin duda, según su naturaleza, no puede reducirse al instante temporal del acto culpable, más bien, a través de él se produce algo que permanece y subsiste pues como dice nuevamente Aquino, "Dos cosas han de pensarse en el pecado: el acto culpable y la mancha que se deriva de él" (Ibid: 100).

No es posible permanecer impune ante el pecado: una vez cometido se adquiere, de forma automática, el carácter de pecador al igual que el de culpable; de esta manera se comprende que el pecado y la culpa no son sólo actos sino modos de ser, es decir, quien dice una tontería no por eso es necesariamente falto de inteligencia, pero quien comete un pecado es, inevitablemente, un ser pecador y culpable.

El pecado, como acto que se realiza y a la postre resulta acción cumplida que trasciende a la duración, se instala en el aquí y el ahora del yo, o en el yo mismo con su tiempo y espacio propios. Pero se ha llegado a ese acto a partir de una conducta, es decir, de una vivencia de asignación de sentido que tiene como consecuencia el acto mismo, pero también la acción entendida en tanto que perteneciente al proyecto y ligada al sujeto. La acción del pecado lleva implícita la conducta y el acto; una vez que es acción transforma la calidad del sujeto y lo nombra culpable

Para cometer un pecado se debe asumir una conducta determinada; al cometer la falta, ella es un acto que trasciende y forma parte de la acción; así, el sujeto, en su aquí y ahora, es, por sus actos, acciones y conducta, un pecador, amén de convertirse, en el mismo instante, en ontológicamente culpable. Tras la experiencia del pecado cotidianamente el sujeto se vive como culpable, y se inserta como tal en la sociedad, misma que vive su propio proceso de funcionalidad diaria y que ha estipulado lo que es y quiere decir pecado.

Si bien los pecados han sido definidos como tales, con las características señaladas, se llega a ellos por omisión, es decir, para la doctrina católica ha sido fundamental señalar y jerarquizar entre pecados original, veniales y capitales y nombrar a estos últimos. Sin embargo, es más importante para la teología y para la moral cristiana, al igual que para la doctrina analítica señalar que la importancia de los pecados no es por lo que ellos son, sino por lo que producen -la culpa-- y por aquello a lo que faltan, es decir, las virtudes. Se peca cuando se arremete contra las virtudes; las virtudes son el único camino para que el ser no se pierda a sí mismo.

Normas, patrones, estructuras, el mismo catolicismo ha dictado cuál es el parámetro que todo cristiano debiera seguir indefectiblemente. Como se verá a continuación, más que una realidad concreta, resultan ser líneas rectoras del comportamiento que, quizá, sólo sean alcanzables para algunos privilegiados que, sin duda, serán nombrados santos. Pese a su dificultad de realización, el cristianismo sostiene que son los lineamientos a seguir.

Según la teología cristiana virtud significa que el hombre es verdadero, es la elevación del ser en la persona humana, es lo máximo a lo que puede aspirar el hombre, o sea la realización de las posibilidades humanas. La virtud es una facultad perfectiva; las virtudes son hábitos que dejan marcado el ser del hombre en cuanto principio de operaciones. 
Para el cristianismo la virtudes son teologales, cardinales y morales. Las primeras, jerárquicamente más importantes, son otorgadas al hombre por el despliegue de los dones del espíritu santo y consisten en fe, esperanza y caridad, mismas que, por no estar interesada en realizar un tratado sobre cristianismo, no observaré sino sólo parcialmente. Las segundas, concebidas como goznes sobre los que se mueve la puerta que conduce a la vida, son fundamentales para el presente estudio al ser los paradigmas que ponen en juego al pecado; son, en ese orden: prudencia, justicia, fortaleza y templanza; las tres últimas son también las llamadas virtudes morales.

Doctrinariamente suele señalarse la virtud con la que es menester atacar a cada uno de los pecados capitales, pero siendo estrictos, tal como se plantean dichas virtudes, se trata de derivaciones de las cuatro cardinales. Si bien se dice contra la soberbia, humildad, esta última es una cualidad de la templanza; contra la avaricia, generosidad, ésta corresponde a la virtud de la justicia; contra la lujuria, castidad, que es propia de la templanza; contra la ira, paciencia, que pertenece a la fortaleza; contra la gula, templanza, que es una virtud cardinal; contra la envidia, caridad que, así entendida, forma parte de la justicia (desde otro umbral es una virtud teologal) y, contra la pereza, diligencia, que es propia de la fortaleza.

Resulta entonces fundamental hablar de cada una de las virtudes cardinales, siempre encaminadas a lograr el bien, mismas que se encuentran jerárquicamente concebidas en un orden que no es casual sino que expresa tanto la concepción básica de la realidad, como el principio cristiano según el cual el bien presupone la verdad y la verdad al ser.

Según Santo Tomás de Aquino, las virtudes cardinales tienen, ontológicamente, un orden jerárquico lógico cuyo fundamento lo brinda de la siguiente manera: "el bien propio del hombre es la realización de sí mismo conforme a la razón, esto es, conforme a la verdad de las cosas que existen (...) Este bien de la razón está dado, de acuerdo con el contenido de su esencia, en el conocimiento normativo de la prudencia. Por la justicia, dicho bien pasa a cobrar existencia real: es misión de la justicia imponer el orden de la razón en todos los asuntos humanos. Las otras virtudes --fortaleza y templanza-- sirven a la conservación de ese bien (...) su misión es tener al hombre a salvo del peligro de decaer del bien de la razón. De entre estas dos últimas virtudes, es a la fortaleza a la que corresponde la primacía.

El imperio de la prudencia hace patente, en su obligatoriedad, al bien humano. La justicia es la que propia y primeramente se encarga de traerlo a la realidad existencial. La fortaleza no es en sí misma, por ende, la primordial realización del bien. Su misión consiste en proteger o abrir paso franco a esta realización" (Pieper, 2001: 195-196).

La primacía de la prudencia significa, ante todo, la necesidad de que el querer y el obrar sean conformes a la verdad; pero, en último término, no denota otra cosa que la conformidad del querer y el obrar a la realidad objetiva. Antes de ser lo que es, lo bueno ha tenido que ser prudente, pero prudente es lo que es conforme a la realidad. En concordancia con lo anterior se establece, entonces, que si las restantes virtudes no alcanzan su fin de acuerdo con la prudencia, en modo alguno pueden ser virtudes. Es la prudencia la que brinda las herramientas, valga decir, el conocimiento de la realidad objetiva por vía de la razón, que posibilita el buen funcionamiento de las demás virtudes. 
Al ser la prudencia el fundamento de toda virtud, el cristianismo sostiene que es imposible educar a un hombre en la justicia, la fortaleza o la templanza sin antes y a la par educarlo en la prudencia, esto es, la valoración objetiva de la situación concreta en que tiene lugar toda operación y en la facultad de transformar ese conocimiento de la realidad en decisión personal. La deliberación y el imperio de la prudencia se enderezan de modo exclusivo a la realización concreta de la justicia, la fortaleza y la templanza. Por eso la prudencia es la que esencialmente posee el bien de la razón, y la justicia es su activa realizadora.

A la prudencia le sigue la justicia ya que ambas son las únicas virtudes, entre las distintas cardinales, por las que se ordena el hombre al bien de una manera inmediata, tal es la razón de su primacía. La fortaleza y la templanza sirven para la preservación de este bien en la medida en que se ocupan de modelar las pasiones, a fin de que el hombre no decaiga, por ellas, del bien de la razón.

Se establece también otra distinción según la cual las virtudes que estrictamente reciben el nombre de morales son justicia, fortaleza y templanza y de entre ellas la justicia es la virtud suprema.

"Lo que concierne a la esencia (prudencia) es superior y más noble que lo que atañe a la realización o ejecución (justicia); lo cual a su vez es superior y más noble que lo que dice referencia a la conservación (fortaleza) y eliminación de obstáculos (templanza)" (Ibid: 118).

Bajo esta lógica, la prudencia aparece como el eje rector de las virtudes, pues tal y como se informa no se encuentra en la misma categoría que las otras tres, pero que no serían tales si no actuaran en conformidad con ésta. La prudencia, entonces, se convierte en una especie de sinónimo de la virtud, y su ejecución se desarrolla en seguimiento de la justicia, la fortaleza y la templanza.

"Para la teología clásica de la iglesia, la prudencia es el modo que tiene el hombre de poseer, mediante sus decisiones y acciones, el bonum hominis o bien propiamente humano, el cual no es otra cosa que el bonum rationis o bien de la razón, o lo que viene a ser lo mismo: la verdad. La prudencia es (...) la objetiva mirada que lanza al ser de las cosas (y que) garantiza la conformidad de la acción a lo real; y precisamente es en esa su conformidad con lo real donde encuentra la acción, lo mismo en el orden de la naturaleza que en el de la gracia, la marca de su bondad". (Ibid: 176).

\section{Prudencia}

Primera entre las virtudes, la prudencia tiene dos rostros, uno que se encara con la realidad objetiva y otro que mira a la realización del bien. Medida del querer y del obrar, la medida de la prudencia es "la cosa misma", la realidad objetiva del ser. La prudencia está encaminada a la realización del bien, es decir, de aquello que está conforme a la realidad, lo cual exige un conocimiento de la verdad, un saber que se adquiere en el contacto efectivo con la realidad objetiva. El conocimiento objetivo de la realidad es decisivo para actuar con prudencia. 
Y donde la prudencia es causa, raíz, madre, medida, ejemplo, guía y razón formal de las demás virtudes, toda virtud es, por necesidad, prudente, ya que la prudencia informa a las restantes virtudes, les proporciona su forma esencial intrínseca. Pero no sólo las virtudes, todo el obrar humano y su normatividad --como los diez mandamientos-- se han de entender referidos a la práctica de la prudencia.

Contemplar tanto la realidad objetiva de las cosas como el "querer" y el "hacer", son obligaciones del prudente. Pero en primer lugar siempre se debe observar la realidad y, en virtud y causa de este conocimiento se estará en capacidad de determinar lo que debe o no de hacerse. A partir de lo anterior se entiende el porqué toda virtud depende de la prudencia, y que todo pecado sea, en cierta manera, una contradicción de la prudencia. Asimismo se comprende porque la prudencia es uno de los "lugares" del espíritu en el que se hace visible la misteriosa conexión entre salud y santidad, enfermedad y pecado. Ser prudente es condición del bien en la medida en que "el ser es antes que la verdad y la verdad antes que el bien" (Ibid: 34), aunque igualmente se plantea que "sólo es prudente el hombre que al mismo tiempo es bueno" (Ibid: 36 ), y "bueno es lo que antes ha sido prudente" (Ibid: 38 ).

Sin embargo, la prudencia no apunta directamente a los últimos fines de la vida humana, sino a las vías conducentes a tales fines; su más característica función es su referencia a los caminos y medios no otra que la última y concreta realidad. En este sentido, la palabra prudencia también puede reemplazarse por la de conciencia. El sentido propio de la prudencia es, cabalmente, no sólo el fin de las operaciones humanas, sino también el camino que a él conduzca, y que han de ser conformes a la verdad de las cosas reales.

Cognoscitiva e imperativa, la prudencia tiene esta doble caracterización en la medida en que aprehende la realidad para luego, a su vez, ordenar el querer y el obrar; de ahí se sigue que la prudencia no es sólo conocimiento o saber informativo, sino también acción. Ahora bien, la prudencia, como conocimiento de la acción concreta, implica la facultad de aprehender objetivamente y "en silencio" la realidad y la experiencia.

Tres requisitos principales tiene el perfeccionamiento de la prudencia como conocimiento, lo que también es denominado como virtudes cognoscitivas del prudente: "fidelidad de la memoria al ser, disciplina (docilitas) (y) perspicaz objetividad ante lo inesperado (solertia) (...) las tres miran a lo ya real, al pasado y al presente, a cosas y realidades, por tanto, que son ya de tal y no de cual manera y que ostentan, en lo que tienen de fáctico el sello de una cierta necesidad" (Ibid: 51).

1) Memoria, entendida ésta como fiel al ser, es el primer requisito debido al grave peligro de que la verdad de las cosas reales sea falseada por la voluntad. "El sentido de la virtud de la prudencia es que el conocimiento objetivo de la realidad se torne medida del obrar; que la verdad de las cosas reales se manifieste como regla de la acción. Pero esta verdad de las cosas reales se guarda en la memoria que es fiel a las exigencias del ser. La fidelidad de la memoria al ser quiere decir justamente que dicha facultad guarda en su interior las cosas y acontecimientos reales tal y como son y sucedieron en realidad. El falseamiento del recuerdo, en oposición a lo real, mediante el sí o el no de la voluntad, constituye la más típica forma de perversión de la prudencia, pues contradice del más inmediato modo el sentido primordial de la misma: el de ser el recipiente donde se guarda la verdad de las cosas reales" (Ibid: 47-48). 
2) Docilitas, entendida como saber-dejarse-decir-algo. Esta debe ser nacida de la voluntad del conocimiento real --que implica siempre y necesariamente auténtica humildad-en la medida en que "en las cosas que atañen a la prudencia nadie hay que se baste siempre a sí mismo; sin docilitas no hay prudencia perfecta (...) La indisciplina y la manía de llevar siempre la razón son, en el fondo, modos de oponerse a la verdad de las cosas reales; ambas descansan en la imposibilidad de obligar al sujeto, dominado por sus intereses, a mantener ese silencio que es incanjeable requisito de toda aprehensión a la realidad" (Ibid: 49).

3) Solertia, entendida como la necesaria objetividad ante lo inesperado, lo cual es la facultad con la que el hombre, ante lo súbito, no se limita a cerrar los ojos y arrojarse a la acción, sino que se halla dispuesto a afrontar objetivamente la realidad.

Asimismo, considerada en su dimensión ordinativa, imperativa o autodeterminativa, la prudencia es vista como mandato. El prudente orienta su mirada hacia lo todavía no realizado, en lo que está por realizar; de ahí que apele a la providencia, es decir, a la "facultad que dispone para apreciar, con seguro golpe de vista, si determinada acción concreta ha de ser camino que realmente conduzca a la obtención del fin propuesto" (Ibid: 51). El prudente no espera certeza donde y cuando no la hay, ni se deja tampoco embaucar por las falsas certezas: recibe su seguridad práctica y su potencia determinativa de la experiencia de la vida vivida, del instinto estimativo y la esperanza de que no se cierren al hombre los caminos que conducen a lo que el cristianismo considera que son sus verdaderos fines.

Se puede faltar a la prudencia por medio de un acto positivo de negación u omisión incumpliendo los requisitos propios de la virtud: impremeditación, inconstancia, falta de circunspección y cautela, negligencia en la decisión, falta de rectitud en la deliberación, de madurez en el juicio, o de decisión (como máximo ejemplo se plantea a la lujuria, "ese extravío en los bienes del mundo sensible que escinde la potencia de nuestras determinaciones" Ibid: 53). Deberá, entonces, distinguirse entre falsa prudencia e imprudencia. La más típica forma de falsa prudencia es la astucia que alude a esa especie de sentido estimulador e interesado al que no atrae más valor que el táctico de las cosas, y que es distintivo del intrigante, "hombre incapaz de mirar y obrar rectamente".

Existe, entonces, una relación sobresaliente entre prudencia y magnanimidad ya que ésta última se opone a la mezquindad y a la pusilanimidad propias de la avaricia, misma que a su vez se opone a la prudencia, puesto que la primera virtud no podría ser sin la constante preparación para la autorrenuncia, sin la libertad y la calma serena de la humildad y objetividad llamadas verdaderas.

Cualidad fundamental de la prudencia es ser la potencia que puede metamorfosear el conocimiento de la realidad en práctica del bien. Implica la humildad de percibir con sencillez; la fidelidad de la memoria al ser, el arte de-dejarse-decir-algo, el aprestamiento ante lo inesperado. Prudencia significa moroso rigor, filtro de la deliberación, arrojo temerario ante la acción necesaria. La prudencia es la claridad de la decisión del que ha resuelto hacer la verdad; es conocimiento directivo de la realidad, de lo que se desprende la buena acción. En la 
prudencia se realiza la configuración del deber por el ser y el ser de la prudencia que es puro, preciso, abierto, sencillo.

Ahora bien, cuando se entiende la prudencia como mandato, es propia de su imperio la necesaria resolución y decisión de una acción a ejecutar aquí y ahora. Una de las condiciones esenciales de la decisión es que sólo puede ser tomada por el sujeto que ha de ponerla en práctica; nadie puede descargar en otra persona el peso de la responsabilidad, inseparable compañera de la decisión. Sólo la persona que efectivamente se decide, y nadie más que ella, experimenta (o puede experimentar) la situación concreta en que se realiza la acción. La única garantía de la bondad de la acción humana singular la da la virtud de la prudencia; a nadie sino a ella, afirman, compete el oficio de emitir un juicio recto sobre la materia concreta, donde se diga cómo hay que obrar ahora. Así, la prudencia como conformadora del ser parte del principio de que "el operar humano presenta dos formas fundamentales: el obrar (agere) y el hacer (facere). La obra resultante del hacer son las formaciones objetivas de fabricación artística y técnica. La obra que resulta del obrar somos nosotros mismos" (Pieper, 2001: 68).

Las acciones prudentes son los pasos que llevan al hombre a la realización de sí mismo. La forja de la persona humana se lleva a cabo mediante la respuesta, en cada caso adecuada, a una realidad que no ha sido creada por el hombre y cuya esencia es la pluriforme mutabilidad del nacer y el perecer. Formular la respuesta adecuada en cada caso, sólo puede hacerlo la virtud de la prudencia; donde se deduce que no es el sentido ni el oficio de la prudencia el descubrir los fines, o, mejor, el fin de la vida, ni el establecer las disposiciones fundamentales de la esencia humana. El sentido de la prudencia es encontrar las vías adecuadas a esos fines y determinar la actualización, conforme al aquí y al ahora, de esas disposiciones fundamentales. Como resultado de sus cualidades, la prudencia es conocimiento que mira lo real, pasado y presente, y es mandato que atiende la acciones en el futuro. A la vez, conocimiento y mandato se convierten en las premisas que hacen funcionar, en el ser, la maquinaria de la prudencia.

\section{Justicia}

Segunda de las virtudes cardinales, íntimamente ligada a la prudencia, la justicia es la capacidad de vivir en la verdad con el prójimo, lo cual depende del conocimiento y reconocimiento de la realidad. En tanto que descubrimiento y patentización de la realidad, la verdad es un supuesto básico y fundador de la justicia. También la justicia es entendida como apetito racional, puesto que a la verdad sólo se llega con el orden de la razón, y la falta de objetividad es casi sinónimo de injusticia.

Cualidad peculiar de esta y sólo de esta virtud es que, gracias a que los deberes propios de la justicia son casi independientes de los cambios situacionales, y a que la diversidad de formas de injusticia sirve para hacer patente la diversidad de formas de justicia, éstas se puedan determinar de una vez y para siempre.

Justicia es que el hombre dé al hombre lo que a éste le corresponde: "he aquí el fundamento en el que se basa toda justa ordenación sobre la tierra. Toda injusticia significa, en cambio, que le es retenido o quitado al hombre lo que es suyo, y que le es quitado o retenido no por la desgracia, la mala cosecha, el fuego o el terremoto, sino por el hombre" (Ibid: 86). 
Una acción realizada con justicia no solamente se funda en el acto por el que algo pasa a ser debido, sino que supone además el acto de la prudencia, que se endereza a plasmar en conducta la verdad de lo real.

Según Santo Tomás de Aquino, "en lo que compele a la virtud de la justicia, es el hábito de la voluntad lo que inclina al hombre a dar a cada uno lo suyo" (Ibid, 2001: 87). Por ende, lo primero que se le ha de pedir a quien haya de ser justo es que prescinda de sí mismo. $\mathrm{Si}$ el acto de la justicia consiste en dar a cada uno lo suyo es porque dicho acto supone otro precedente, por virtud del cual algo se constituye en propiedad de alguien. Esta proposición enuncia una realidad: la justicia es algo segundo, presupone al derecho. $\mathrm{Si}$ algo se le debe a un hombre como suyo, el hecho mismo de que tal se le deba no es en sí obra de la justicia. El acto por el cual se constituye inicialmente algo en propio de alguien, no puede ser un acto de justicia. El concepto de derecho de lo debido, en el cual ser debido significa tanto como corresponder y pertenecer, es una noción hasta tal punto radical y primaria que no se deja reducir a ninguna otra que le fuese anterior y de la cual pudiera ser derivada. Por eso es un concepto que no puede ser definido sino, todo lo más, descrito. Cabe decir que lo debido es lo que un individuo tiene derecho a reclamar de otro como algo que se le adeuda y que no corresponde a nadie más que a él; lo adeudado puede ser una cosa o una acción.

"Un sencillo acuerdo del tipo de una promesa puede muy bien ser razón bastante para que, por su virtud, algo me sea en verdad debido. Quien no restituye lo debido se hace digno de compasión ¿cuál es la causa de la irrevocabilidad de este débito? que el débito se funda en la naturaleza misma del ser a quien es debido. Un débito, en el pleno sentido de la palabra, inviolable e irrevocable, sólo puede darse a condición de que el adeudado esté de tal manera constituido que posea la facultad de reclamar como su derecho lo que se le debe. En strictu sensu, sólo los seres espirituales ${ }^{21}$, es decir, humanos, tienen derechos irrevocables" (Ibid: 94). $\mathrm{Si}$ no se reconoce la personalidad del hombre en su íntegra realidad, desaparece toda posibilidad de determinar el fundamento del derecho y de la justicia.

Destino peculiar de la virtud de la justicia es el tener por misión ordenar al hombre en su relación con el otro; mientras que las demás virtudes se limitan a perfeccionar al ser humano cuando se lo considera tan sólo en sí mismo, la justicia implica una referencia al otro. De esta manera, ser justo significa reconocer al otro en cuanto otro, o lo que es lo mismo, "estar dispuesto a respetar cuando no se puede amar". La justicia enseña que hay un otro que no se confunde conmigo, pero que tiene derecho a lo suyo; así, la justicia consiste en la recíproca convivencia; la acción del justo por su misma esencia está referida a otro.

De preferencia la justicia se consuma en una acción externa; por el contrario, lo que hay que tener en cuenta en la esfera de la fortaleza y la templanza --las otras dos virtudes morales-- es, ante todo, la disposición interna del sujeto, y sólo en segundo lugar, el comportamiento exterior del mismo. Y de entre las virtudes morales la justicia es la virtud suprema, ya que "el hombre que mejor merece ser llamado bueno es el justo; es superior

${ }^{21}$ Un ser espiritual es "aquel que es un todo en sí, que existe para sí y por sí y en vista de su propia perfección (lo cual es) la condición del ser espiritual por la cual éste es dueño de sus propios actos" (Pieper, 2001: 95). 
porque 1) no solamente ordena al hombre en sí mismo, sino también la mutua convivencia; excede los límites del sujeto individual con lo que viene a constituirse en bien del otro y 2) no sólo por razón del objeto y la materia sino por razón del sujeto en ella puesto que, a diferencia de las otras dos virtudes, que se dirigen al cuerpo y alma del sujeto, ésta anida principalmente en el espíritu del mismo" (Ibid: 115-116). La justicia, junto con la prudencia, son las virtudes cardinales que ordenan al hombre a hacer el bien.

Debe señalarse que en la esfera de la justicia se da una separación entre la acción y la intención. La ejecución del acto de justicia cae bajo precepto en la medida en que éste exige que algo sea realizado conforme al orden del derecho, mas no porque la realización de ese algo proceda del hábito de justicia. Sólo por la acción externa se le restituye, en rigor, lo que es de alguien y le corresponde; los hombres se ordenan los unos a los otros mediante actos externos; así, todo acto de justicia es una acción externa y es igualmente cierto que toda acción externa cae dentro de la esfera de la justicia. Toda acción externa, que tiene trascendencia social, puede ser considerada desde tres perspectivas: 1) por la relación y proporción que guarda con el agente; 2) por su relación y proporción al otro y 3) en sí misma (cfr. Ibid: 109).

La justicia encuentra pleno cumplimiento cuando las tres principales formas de relación, o lo que es lo mismo, las tres estructuras fundamentales de la vida común se encuentran ordenadas, momento al que se le reconoce como de plenitud óntica del "nosotros". Estas estructuras son 1) las relaciones de los individuos entre sí, 2) las relaciones del todo social para con los individuos, y 3) la relación de los individuos para con el todo social. A estas tres formas de relación responden las tres principales formas de justicia: 1) justicia conmutativa o reparadora, que regula la relación del individuo con el individuo; 2) justicia distributiva o asignadora, que regula la relación de la comunidad en cuanto tal para con sus miembros, y 3) justicia legal o general, que regula la relación de los miembros para con el todo social. Estas tres formas se caracterizan porque en cada una de ellas se presenta lo debido en una configuración distinta; así como diferente es también el sujeto al que se dirige el requerimiento (cfr. Ibid: 123-125).

Estas tres formas de justicia son mutuamente irreductibles aunque la conmutativa es el núcleo de la coexistencia humana porque 1) sólo en la mutua relación entre individuos puede realmente decirse que cada una de sus partes haga frente a la recíproca como un otro independiente. En las otras formas básicas de relación, ya sea del individuo con "nosotros" (legal) o la del "nosotros" con el individuo (distributiva) es imposible que el otro se presente al individuo de forma separada a él. 2) Sólo en la justicia conmutativa se realiza, sin restricción alguna, la condición de igualdad y paridad de derechos entre las distintas partes. Lo anterior manifiesta un segundo elemento clave del verdadero concepto de justicia: la justicia absoluta sólo se da entre aquellos que son absolutamente iguales. Justo, según el modo de la justicia conmutativa, es el individuo que da al otro, es decir, al que no está de antemano vinculado a él, al extraño, lo que se le debe. La justicia conmutativa pone a funcionar la lógica de la restitución, es decir, la acción de poner a uno de nuevo en posesión y dominio de lo que le pertenece a diferencia de la justicia distributiva en la cual lo que se le debe al individuo no es cosa de su exclusiva e individual pertenencia, sino la participación en lo que pertenece a todos (cfr. Ibid: 127-138). 
Bien se establece que la justicia no excede nunca los límites de lo debido, lo que se adeuda; por ejemplo, lo donado no es un acto de justicia ya que lo donado no es, en rigor, debido; sin embargo se enfatiza, en cuanto a los límites de la justicia que, so pena de inflingir serio perjuicio al normal curso de la vida, es menester estar dispuesto a dar no sólo lo debido, sino también lo que, estrictamente hablando, no se está obligado a dar, ya que el exclusivo cálculo de lo debido torna fatalmente inhumana la vida en común. De ahí que para el cristianismo la justicia sin misericordia sea sinónimo de crueldad.

"La perversión última de la humanidad no está en la inmoderación, cuya presencia es ineludiblemente delatada por el rostro o el ademán del sujeto que la alberga, sino en la injusticia, que puede ser disimulada con tanta más facilidad, por cuanto tiene en el espíritu su esencial residencia" (Ibid: 19).

\section{Fortaleza}

Tercera entre las virtudes cardinales y que sólo existe donde se quiere la justicia, informada por la prudencia, la fortaleza se reconoce como la disposición para realizar el bien aún a costa de cualquier sacrificio.

Estrechamente relacionada con la resistencia y la paciencia, la fortaleza se encuentra lejos de la temeridad; por el contrario, fortaleza no significa no tener miedo, pero es el temor a la mutilación o aniquilación del ser. "Lo realmente terrible no es más que la posibilidad que tiene el hombre de separarse voluntariamente, por su propia culpa, de su última razón de ser. La posibilidad de ser culpable es el mayor peligro para la existencia del hombre. El temor de dios es la respuesta adecuada a este horror de la separación culpable y siempre posible de su última razón de ser. Esta culpabilidad es lo que definitivamente hemos de temer" (Ibid: 22).

Un supuesto básico de la fortaleza es la vulnerabilidad; sin ella no se daría ni la posibilidad misma de la fortaleza. Si el hombre puede ser fuerte es porque esencialmente es vulnerable, puede recibir una herida de cualquier índole, incluso la más fuerte, que es la muerte. De este modo, la fortaleza está siempre referida a la muerte; ser fuerte es, en el fondo, estar dispuesto a caer, a morir. Una fortaleza que no descienda hasta las profundidades del estar dispuesto a caer, está "podrida de raíz y falta de auténtica eficacia". Tal disposición se manifiesta en el riesgo de la acción; así, para el cristianismo, el reto propio y supremo de la virtud de la fortaleza es el martirio.

Sin embargo, el recibir una herida no constituye la esencia de la fortaleza, sino tan sólo la mitad exterior de ella. El fuerte no recibe la herida por su propia y espontánea voluntad, sino por conservar o ganar una integridad más esencial y honda: ser fuerte significa estar dispuesto a recibir una herida en aras del bien. Al hacer frente al peligro, no es el peligro lo que la fortaleza busca, sino la realización del bien de la razón. De ahí que la fortaleza no sea la primera ni la más grande de las virtudes, pese a ser la que exige del hombre lo más dificil; no es la dificultad ni el esfuerzo lo que constituyen a la virtud, sino únicamente el bien. De esta manera, la fortaleza remite, por tanto, a algo que por naturaleza es anterior; su sentido propio le viene sólo de su referencia a algo que no es ella: sin prudencia y sin justicia no se da la fortaleza. Por lo tanto, para hablar de la esencia de la fortaleza debe considerarse la relación a la prudencia y a la justicia implicadas en dicha virtud. 
Ser fuerte o valiente no es lo mismo que no tener miedo: el fuerte ni ama la muerte ni desprecia la vida. La fortaleza supone el miedo del hombre al mal, y lo que mejor caracteriza su esencia no es el no conocer el miedo, sino el no dejar que el miedo le fuerce al mal o le impida realizar el bien. Valiente es el que no deja que el miedo a los males perecederos y penúltimos le haga abandonar los bienes últimos y auténticos, inclinándose ante lo que en definitiva e incondicionalmente hay que temer. Sólo el que realiza el bien haciendo frente al daño, es verdaderamente valiente. Pero este hacer frente a lo espantoso presenta dos modalidades que sirven de base a los dos actos capitales de la fortaleza: resistencia y ataque. $\mathrm{El}$ acto más propio de la fortaleza es resistir; es en ese caso de extrema gravedad cuando la resistencia es, objetivamente, la única posibilidad que resta de oponerse, y sólo y definitivamente en una situación tal es cuando la fortaleza muestra su verdadera esencia.

Enérgica actividad del alma, la resistencia es un acto de perseverancia en la adhesión al bien. La fortaleza es paciencia y paciente es quien no es que huya del mal, sino que no se deja arrastrar por su presencia a un desordenado estado de tristeza. Ser paciente significa no dejarse arrebatar la serenidad ni la clarividencia del alma por las heridas que se reciben mientras se hace el bien; la paciencia es incompatible con la tristeza y el desorden del corazón; la paciencia preserva al hombre del peligro de que su espíritu sea quebrantado por la tristeza y pierda su grandeza; la paciencia es la columna que ante nada se doblega y la que mantiene al hombre en posesión de su alma. La confianza, que es parte de la fortaleza, lleva consigo la esperanza que pone el hombre en sí mismo (cfr. Ibid: 201-202).

En aras del bien, el valiente debe apoyarse en lo que le sea necesario, incluso en la ira, sobre todo al atacar, porque el abalanzarse sobre el mal es lo que resulta propio de la ira cuando no es un pecado; de ahí que la ira pueda entrar en cooperación inmediata con la fortaleza, aun cuando el ataque es el último reducto de la fortaleza, puesto que su esencia se concibe como de resistencia y paciencia. Cuando la palabra sagrada dice "mas yo os digo que no os opongáis al malvado; antes bien, al que te golpee la mejilla derecha, ofrécele también la izquierda", apela a la fortaleza en el sentido de la disposición del alma a soportar, cuando sea preciso, sin dejarse vencer por la amargura, una segunda afrenta igual o todavía más grande, del agresor (cfr. Ibid: 205).

Santo Tomás de Aquino, para quien la fortaleza sobresale entre las primeras condiciones de la perfección, distingue tres grados de sublimación de la fortaleza: 1) El inferior, que no es abandonado cuando se asciende al que le sigue, sino incorporado, y se representa por la fortaleza política de la vida en común, ordinaria y cotidiana. Ella implica a la paciencia, la resistencia y, en última instancia, al ataque; 2) Purificador o purgatorio que se da en la vida mística, y 3) Fortaleza del espíritu purificado que se alcanza en la santidad terrena (cfr. Ibid: 210-211).

Como tal, la fortaleza es en la medida en que está informada --en el sentido de brindar la información intrínseca-- por la prudencia a través de la justicia, pues la prudencia tiene dos rostros: uno cognoscitivo y mesurado, que está vuelto hacia la realidad y otro, resolutivo, perceptivo, mensurante, que mira al querer y al obrar. En el primero se refleja la verdad de las cosas reales; en el segundo se hace visible la norma del obrar. Sin la cosa justa no hay fortaleza, la cosa es lo que decide y no el daño que se pueda sufrir, la fortaleza sin justicia es 
palanca del mal. Lo que constituye la esencia de la fortaleza no es el exponerse de cualquier forma a cualquier riesgo, sino sólo una entrega de sí mismo que es conforme a la razón y, con ello, a la verdadera esencia y al verdadero valor de lo real. La auténtica fortaleza supone una valoración justa de las cosas, tanto de las que se arriesga como de las que se espera ganar. Ser valiente no significa tan sólo ser herido y muerto por la realización del bien o de lo que es bueno, sino también implica esperanza en la victoria. Sin esperanza no es posible la fortaleza (cfr. Ibid: 194-215).

\section{Templanza}

Última, la templanza es la virtud más personal entre las cuatro cardinales. En su sentido propio y primigenio templanza es hacer un todo armónico de una serie de componentes dispares: poner freno, parar, respetar, tratar con miramientos una cosa, recta proporción, adecuada estructura; ordenamiento con sentido; criar, cultivar, educar. Como sentido y finalidad de la templanza se encuentra el hacer orden en el interior del hombre a partir de la tranquilidad del espíritu, es decir, de ese núcleo activo en el que se cuecen las decisiones del hombre.

Lo que distingue a la templanza de las demás virtudes cardinales es que tiene su verificación y opera exclusivamente sobre el sujeto actuante. La templanza se revierte sobre el mismo que la ejercita. Actuar con templanza quiere decir que el hombre se enfoca sobre sí y sobre su situación interior; que tiene puesta sobre sí mismo la mirada y la voluntad. Dos formas tiene el hombre de convertirse a sí mismo: "una desprendida y otra egoísta; sólo la primera garantiza la autoconservación mientras que la segunda destruye. De ello se deriva que la templanza es autoconservación desprendida; la falta de templanza equivale a la autodestrucción por la degeneración egoísta de las energías destinadas a la autoconservación" (Ibid: 225-226).

La templanza es el hábito que pone por obra, conserva y defiende la realización del orden interior del hombre. Las formas originales del placer permiten la conservación del hombre, pero cuando se desordenan pueden destruirlo, de ahí que las formas originarias de la templanza sean la abstinencia y la castidad. Castidad, sobriedad, humildad, mansedumbre, son formas en que aparece la templanza, así como lujuria, desenfreno, soberbia y cólera que no entiende de razones son formas en las que hay destemplanza.

La templanza es moderación por medio de la influencia espiritual de un orden dictado por la razón. "La idea de un orden de la razón no quiere decir que exista un algo mental absoluto y desprendido del orden objetivo, con lo cual tengan que coincidir las cosas. La ratio no es otra cosa que el sentido de lo externo visto por nosotros, por lo que nos relacionamos con ello (...) la razón (...) será aquello que está de acuerdo consigo mismo, es decir, aquello que como verificación de sí misma corresponde a una cosa. El ordo rationis significa, entonces, que algo está ordenado según la verdad de lo real" (Ibid: 234).

Dado que cada individuo responde de manera distinta ante las pasiones, el contenido de la templanza no puede fijarse sino hasta que el individuo se observa a sí mismo. La concreción de la templanza varía según los tiempos y las personas, por eso no es posible establecer prescripciones positivas y de valor universal respecto a ella. Sin embargo, "de 
cómo se entienda la templanza dependerá la postura que se adopte respecto del mundo exterior a nosotros" (Ibid: 230).

Las virtudes, en tanto que modos de ser, deberían formar parte intrínseca del sujeto y de sus vivencias y así trascender la duración, instalarse en el aquí y el ahora del yo, o en el yo con su tiempo y espacio propios. Se actuará virtuosamente cuando se asuma dicha conducta, es decir, la de la vivencia de asignación de sentido que tendrá como consecuencia los actos mismos, pero también las acciones, entendidas en tanto que pertenecientes al proyecto y ligadas al sujeto. Las acciones virtuosas llevarán implícitas la conducta y los actos; una vez que sean acciones transformarán la calidad del sujeto, probablemente convirtiéndolo en santo.

Para actuar virtuosamente se debe asumir ésta conducta que, una vez adoptada, queda en los actos que trascenderán y formarán parte de la acción. El sujeto, en su aquí y ahora, será, por sus actos, acciones y conductas, un virtuoso, amén de acceder, en el mismo instante, a vivir en gracia con dios. Cotidianamente el sujeto se vivirá como virtuoso, tras evitar la experiencia del pecado y se insertará como tal en la sociedad, misma que vive su proceso de funcionalidad diaria y que ha estipulado lo que quiere decir virtud.

\section{Crimen y castigo}

Este es o sería el orden de los acontecimientos y de la experiencia; sin embargo, lo que se constata es que el pecado forma parte de la experiencia fáctica del sujeto, lo define, lo que no sucede en el caso de las virtudes. Según lo señalé, con suerte algunos santos lo habrán logrado. Las virtudes deberían convertirse en parte constitutiva del obrar humano bajo una lógica de funcionamiento encaminada al bien, pero ello no es lo que define al hombre: la humanidad es tal por ser pecadora, no por ser virtuosa; se constituye por el mal y no por el bien; la maldad le es intrínseca, la virtud debe buscarla con ardua y afanosa entrega y labor.

Temor y obediencia serán ejes rectores del cristiano; su experiencia cotidiana estará mediatizada por estos estigmas pues de lo contrario se pondrá en marcha sobre un camino del que no hay retorno posible. Las faltas cotidianas o pecados veniales serán significativos en la vida del sujeto, aunque podrá sortearlos, sobre todo porque la sociedad misma brinda opciones para que, ahí donde es posible, es decir, cuando no se ha cometido pecado mortal, existan formas de expiación; actos ritualizados tanto a nivel individual como colectivo.

De aquí la necesidad de la expiación, que al mismo tiempo resulta ser lo que demuestra la potencia de la culpa; es decir, su existencia, marcada como necesaria, es lo que vincula a la culpa con el pecado y la virtud y permite reconocer su peso: si hay algo de qué arrepentirse, que debe pagarse, ante lo que se debe sufrir, ese algo no puede ser inocente, ni amable, ni bueno, por el contrario. La expiación, que se encuentra constituida por la confesión, la penitencia y el sacrificio, es, entonces, lo que da la indicación de la fuerza de la culpa

"Pero el pecado, como este acto puesto en un determinado momento, no sólo funda una mancha permanente del alma, un obscurecimiento de su luminosidad, un alejamiento de dios, una servidumbre (y también como la teología dice, un debilitamiento de la receptividad para la gracia...); constituye además, y sobre todo, una disposición ontológica que penetra con 
mayor profundidad en el núcleo de la persona. Los antiguos usaban para esto un nombre que se hizo clásico, pero que ha caído en desuso: reatus. La palabra se deriva de reus, culpable, y designa el estado de culpabilidad. Pecado no significa solamente: yo he hecho algo, sino también: yo soy ahora algo que antes no era; yo soy culpable a causa de esa acción. El ser culpable es lo que brota en la acción del pecado como fruto interno, como efecto. Decir que el pecado como acto es algo transitorio y como reato algo permanente, es lo mismo que decir: pasa en lo que es, pero permanece en lo que produce. $\mathrm{Si}$, por lo demás, he definido el reato como estado de culpabilidad, hemos de advertir que esto, estrictamente hablando, sólo es acertado bajo un determinado presupuesto. Este presupuesto es el de que se atienda a una implicación que no es extraña a nuestro uso cotidiano del lenguaje, donde el delincuente no sólo es llamado culpable, sino también reo de muerte. El reato, como fruto interno y permanente del pecado, significa, pues, una doble cualidad de la persona, tanto la de la culpabilidad, del tener culpa, como la de merecer castigo, la del reato de pena, de la obligato ad poenam" (Pieper 1986: 103-104).

Aparece pues que toda culpa merece un castigo "en la tradición intelectual de la humanidad nunca ha habido duda sobre la relación necesaria entre culpa y expiación (pues) si se da la culpa y el pecado en un sentido íntegro, entonces es razonable y necesario que exista también expiación y pena, quienquiera que sea el autorizado para imponerla. Pecado y culpa son algo sancionable por naturaleza" (Ibid: 104-105).

El cristianismo o los cristianos han establecido diversas formas de castigo. Si bien se dice que se debe aspirar al perdón para lo cual es necesario conocer, reconocer y rechazar la propia culpa, al igual que buscar la expiación del pecado, lo cierto es que el problema es más complejo puesto que, si bien todo pecado tiene la misma naturaleza, no todos son de la misma magnitud. Ante el pecado mortal se plantea la necesaria existencia de una pena infinita, para los pecados veniales, la confesión; pero por el pecado original la humanidad permanecerá, por los siglos de los siglos, culpable.

Lo primero que aparece como necesario para acceder a la expiación es el conocimiento y reconocimiento de la falta, es decir, la confesión de la misma a partir de lo cual puede establecerse la magnitud del pecado. En la confesión --que no necesariamente ha de entenderse como el sacramento de la iglesia, sino como la declaración, y en esa medida entrega, que se hace de algo que se sabe o que se ha hecho, visto o recibido-- van implícitos el arrepentimiento, aceptación a la vez que negación de lo cometido, pena, dolor, sufrimiento, vergüenza, y puede llevar a la opresión y la angustia. La confesión implica también el hacer del conocimiento público la conducta y el acto cometido o las acciones realizadas, lo cual obliga a actuar en consecuencia.

Dícese pues que no se puede cometer pecado sin reconocerlo y al asumirlo no es posible no confesarlo: "Si preguntamos por los presupuestos de una curación de la culpa y del pecado, la referencia a la necesidad del arrepentimiento sólo es una parte de la respuesta. Es también condición indispensable para la liberación interna la propia acusación, la expresión de la propia culpa, la confesión en presencia de alguien" (Ibid: 113) $y$, tras ello, es menester pagarlo "porque en el pecado no sólo se lesiona una norma objetiva y neutral, sino que es atacado un alguien personal, propiamente habría de poderse hacer 
plausible que ni el arrepentimiento ni la confesión, que son ambos actos unilaterales, pueden bastar para que uno se vea realmente libre de su culpa" (Ibid: 114).

\section{Ilustración: Confesión}

(Intérprete: Domingo Rubio)

Apertura, entrega, palabra dada: confesión. Ahi hay un hombre semidesnudo sobre un pie y nada más a su alrededor. El único tobillo que sostiene al esbelto cuerpo, tanto como los músculos de la pantorrilla, se denotan tensos en el esfuerzo; la rodilla muestra claramente su condición de bisagra; en la corva se apoya el otro pie con una sutil fuerza que revela que forma parte del esfuerzo que mantiene el equilibrio; por ende, hay fuerza en los gemelos y en los abduptores. La pierna bastión es fuerte en el muslo aunque, por la posición, la solidez le viene del abductor. La cadera se encuentra perfectamente colocada en su centro, lo que posibilita mantener la posición a la vez que cierta torsión de la parte superior. Con una breve inclinación hacia la derecha y un poco más prolongada hacia abajo, el torso muestra la musculatura, evidentemente trabajada; aparecen los abdominales, los torales y los dorsales todos un tanto esforzados; en la parte superior, entre los hombros y el cuello, se concentra toda la tensión: las claviculas, los trapecios, los tendones del cuello son excesivamente notorios. Los delgados brazos están extendidos hacia el frente y un poco hacia abajo; las manos, un tanto rotadas hacia fuera, abiertas y alargadas, continúan la acción de los brazos en un gesto de apertura y entrega. El rostro tiene marcada la mandíbula y los pómulos, los delgados labios y la boca entreabierta crean una mueca de arrepentimiento enfatizada en la mirada, en la que también hay dolor, y el ceño y la entreceja, un poco fruncida, asimismo en calidad de dolor.

Un hombre confeso, su equilibrio, su fuerza, su musculatura, su articulación, su gesto, sus manos se ofrecen; no tiene reserva alguna; se brinda, se entrega, se da. Ahí está. Precaria mas sin titubeos, la base sostiene la arbórea figura de joven masculinidad. La pantorrilla prolonga el bien asentado equilibrio de un pie que cobra mayor seguridad con el apoyo brindado por el otro pie que encaja en la corva bastión. Los músculos resaltados revelan la fuerza ejercida para sostener tan peculiar situación. El vientre, macizo centro que lucha contra la gravedad. Al hundirse, el pecho reafirma la inclinación. Clavículas, trapecios, hombros, cuello portan, transportan y soportan una enorme tensión que fluye, dilatada y dilatando -músculos, venas, arterias, tendones-, hacia las manos que, resignadas, manifiestan su intención y se rinden. Todo lo que el cuerpo expresa cabe en el gesto del rostro. La cabeza inclinada, el ceño fruncido, la mirada baja, la boca declarante enfatizan la rendición. La reflexión y reconocimiento han dejado al cuerpo en tensión, en precario equilibrio, en irremediable exteriorización. Intimidad desvelada, revelada, expuesta. El cuerpo ha hablado. El hombre se ha confesado.

El sentido de la culpa adquiere dimensiones exorbitantes tal y como se revela en los actos encaminados a minimizar la falta; en una situación liminal -la que lleva al pecado mortal o a su expiación-- se llega siempre a atentar contra el cuerpo, así, la flagelación, el martirio, el sacrificio, imponen dolor al cuerpo -como mecanismo de placer o displacer-para ver si con ello se libera el dolor del alma; es el cuerpo el vehículo con el que se busca una transformación que, en realidad, nunca llega, pues la culpa, por mucho que se descargue en el cuerpo, permanece en el alma. A lo anterior habrá que sumar un dato 


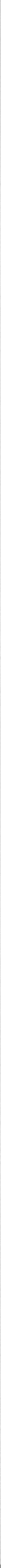


propio de la lógica del sacrificio, la penitencia y la piedad cristiana, que en mucho se sustentan en la eterna deuda con dios, que no se podrá pagar ni restituir, de ahí entonces que cualquier pena, nunca será suficiente para estar bien con el creador.

Toda confesión implica, entonces, necesariamente, una penitencia, entendida aquí no como el sacramento, sino como una serie de ejercicios penosos con que se procura la mortificación de las pasiones y los sentidos para satisfacer la justicia divina, es decir, por medio de los cuales se busca el perdón de los pecados cometidos. La penitencia es el castigo autoimpuesto u ordenado que implica necesariamente pena y disciplina y que puede llegar a buscar dolor, sufrimiento, martirio, suplicio o tormento, según qué tan necesitado se esté de piedad.

"La penitencia purifica el alma, eleva el pensamiento, somete la carne propia al espíritu, hace al corazón contrito y humillado, disipa las nebulosidades de la concupiscencia, apaga el fuego de las pasiones y enciende la verdadera luz de la castidad" (San Agustín en Baduí Dergal, 2001: 12). Y habrá que enfatizar que todo castigo, toda penitencia, todo sacrificio es, en principio y muchas veces hasta el final, un sometimiento del cuerpo: martirizarlo, maltratarlo, dolerlo, lastimarlo; arremeter contra el cuerpo... siempre el cuerpo.

\section{Ilustración: Penitencia}

\section{(L'Arche de Noé)}

Un cuerpo en extraña posición surge de la oscuridad dirigiéndose a la única fuente de luz que le golpea de frente; está cubierto totalmente de una sustancia terrosa. El torso, inclinado hacia delante, es un tanto robusto, con la musculatura poco marcada, de hecho no podría decirse que es delgado, aunque la penumbra no permite observar mucho más. Los hombros y los trapecios lucen con fuerza aunque no con tensión; lo mismo sucede con los brazos, colocados incómodamente hacia atrás en busca de lo que sostienen o lo que evita que el hombre caiga, pues no se puede asegurar si está evitando su caída o jalando algún peso. Las manos sostienen unas cuerdas, firmes aunque no con mucho esfuerzo. En el juego de sombras se pierde el cuello que, por la posición de la cabeza, se adivina un tanto tenso, por lo menos lo necesario para sostenerla. El rostro aparece de tres cuartos y un tanto inclinado hacia abajo, en correspondencia con la posición del torso. Tiene la boca entreabierta, como de quien vive su último aliento; la nariz recta y afilada y, no se sabe si los ojos están cerrados por la fatiga o miran el lugar donde el cuerpo, con todo su peso y cansancio, ha de caer.

Sostenida de unas cuerdas o tirando de ellas, la figura masculina está a punto de caer por su propia debilidad o por el peso de su tarea. Completamente cubierta de tierra o barro o lodo, las piernas no se alcanzan a ver. El torso pareciera que está obligado a inclinarse, por la carga o la fatiga, y la cabeza cae aún más, pareciera que se desprende. Las marcas en el rostro son de extenuación, rendición, pareciera que va a perderse en cualquier momento. Cuerpo sometido o autosometido a brutal faena o a situación extremadamente precaria. Sacrificio llevado hasta sus últimas consecuencias, por decisión, por imposición; el cuerpo tan sólo revela la pesadumbre de un castigo que, una vez confesado, ha tenido que dirimirse. Despojado el cuerpo de todo bien, purgado de sus 
…
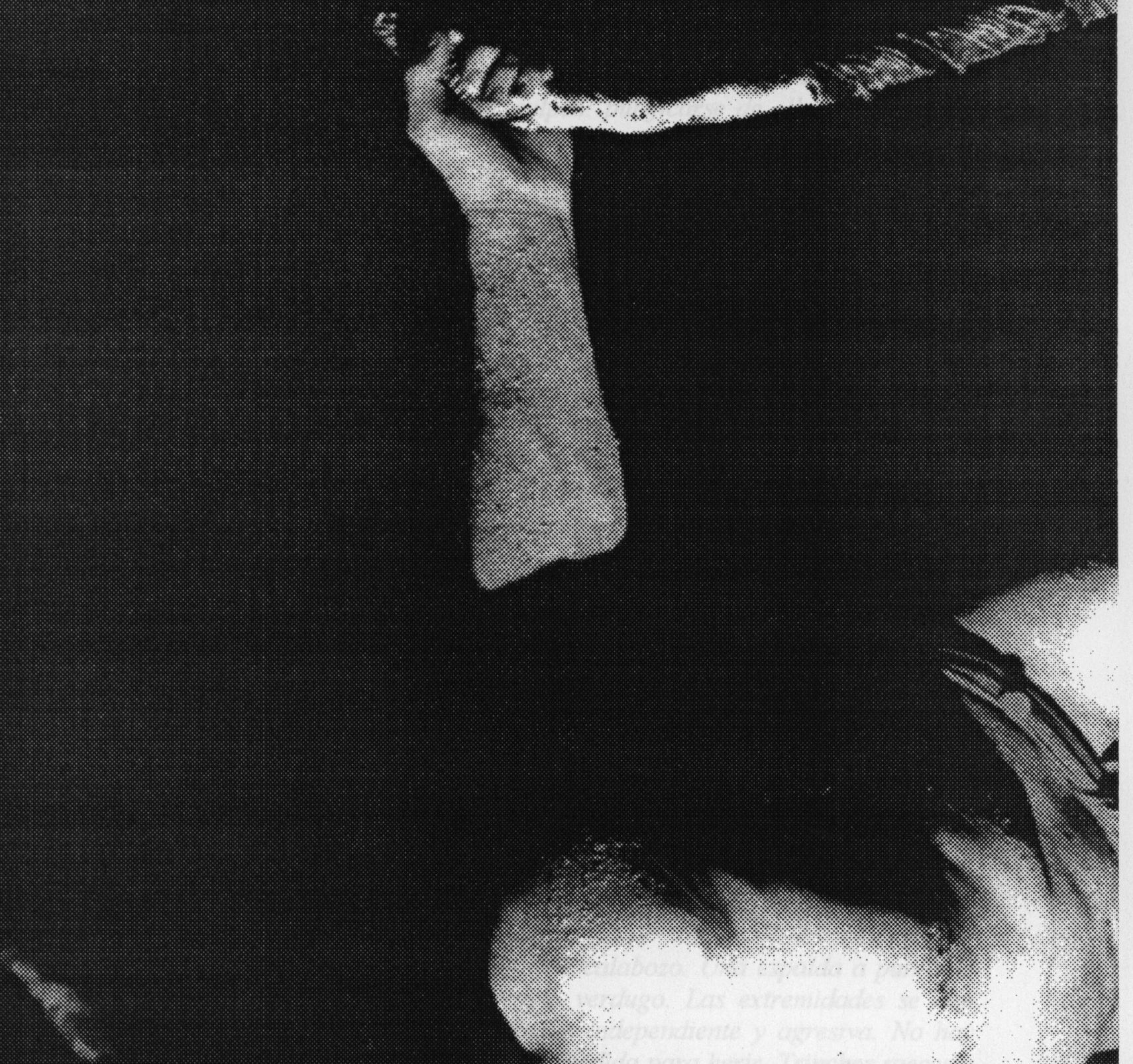

(2)
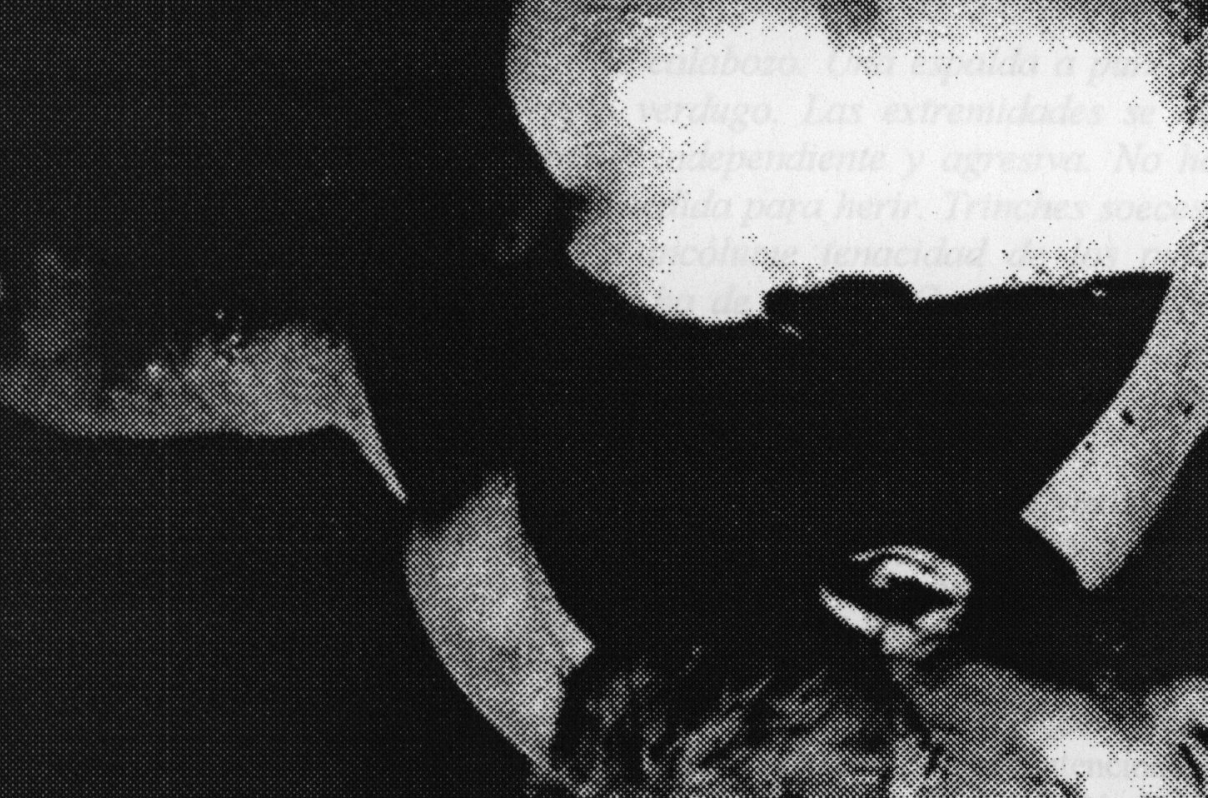
deseos padece y sucumbe ante los trabajos realizados por consecuencia de desaciertos o de malos procederes, acciones tendientes a borrar culpas: purificarse de ellas, sacrificarse ante ellas, amedrentarse por ellas, librarse de ellas. Remembranza de viejas torturas -muerte por descoyuntamiento-- $o$ de añejos suplicios --flagelación en el agotamiento-Evitar el pensamiento, el sentimiento, en el sometimiento físico: cuerpo utilizado, denigrado, alterado, derrotado. Penoso penar del penitente.

Y se llega al sacrificio, entendido como ofrenda dirigida hacia algo -puede ser que a la deidad--, en este caso, en busca de expiación; un acto de abnegación disciplinada que busca el perdón. Los sacrificios tendientes a dirimir culpas son actos ritualizados -como la flagelación, los votos de castigo o los rituales colectivos como la semana santa ${ }^{22}--$, experiencias en momentos liminales a partir de las cuales se pueda retornar al orden del corazón, necesario para mantener al alma alejada de una profunda pena y una gran tristeza. Se pretende que, a través de un acto socializado, el individuo cambie su estatus óntico de culpable.

\section{Ilustración: Sacrificio individual (Cielo)}

Dominada por las sombras aparece la parte superior de una espalda desnuda, que se sabe masculina por la constitución de los dorsales -fuertes--, los omóplatos-tensos por la posición--, los brazos y las manos. Los brazos están hacia arriba, flexionados hacia atrás a la altura de los codos. Cada mano sostiene, entre los dedos índice, medio, anular y meñique, tres clavos que están a punto de hundirse en la parte interior de los omóplatos, acción que provoca dobleces en la piel. Los brazos, pero sobre todo las manos, se encuentran tensos por el esfuerzo, lo que se revela en las venas, músculos y tendones resaltados. La cabeza se pierde en la oscuridad.

Penumbroso, aire de catacumba, atmósfera de calabozo. Una espalda a punto de ser sacrificada porta los brazos que son su propio verdugo. Las extremidades se han transformado adquiriendo una vida monstruosamente independiente y agresiva. No hay nada más. La totalidad de la imagen es la fuerza desmedida para herir. Trinches soeces a punto de penetrar la carne desfiguran la piel. La incólume tenacidad de los puños incrementa la tormentosa decisión del castigo que se ha de infligir. Cada tendón, cada músculo, cada circulación de energía involucrada en la empuñadura prepara un estudiado dolor. Atento daño, elaborada concentración del poder que ha de estropear su propia

${ }^{22}$ La semana santa que, amén de recordar la vida y obra de Jesucristo, también mantiene vigente en la memoria que él es el redentor, quien asumió la tarea de librar a los hombres del pecado pagando con su propio sufrimiento y hasta con su vida, lo cual mantiene al hombre en deuda permanente con él e incrementa la dimensión de su culpa cuando, después de tan ardua labor del hijo de dios, todavía insiste en mantenerse en el pecado.

Ritual cristiano por excelencia, en el triduo pascual los participantes pagan deudas, remiendan acciones, muchas veces haciendo del cuerpo lastimado el vehículo de tales intenciones, y la sociedad, en tanto tal, recuerda su fragilidad y su eterna deuda, jamás nunca pagable. No huelga señalar por evidente, aunque no ahondaré en ello, que la construcción de la culpa y del pecado son también mecanismos de poder. 


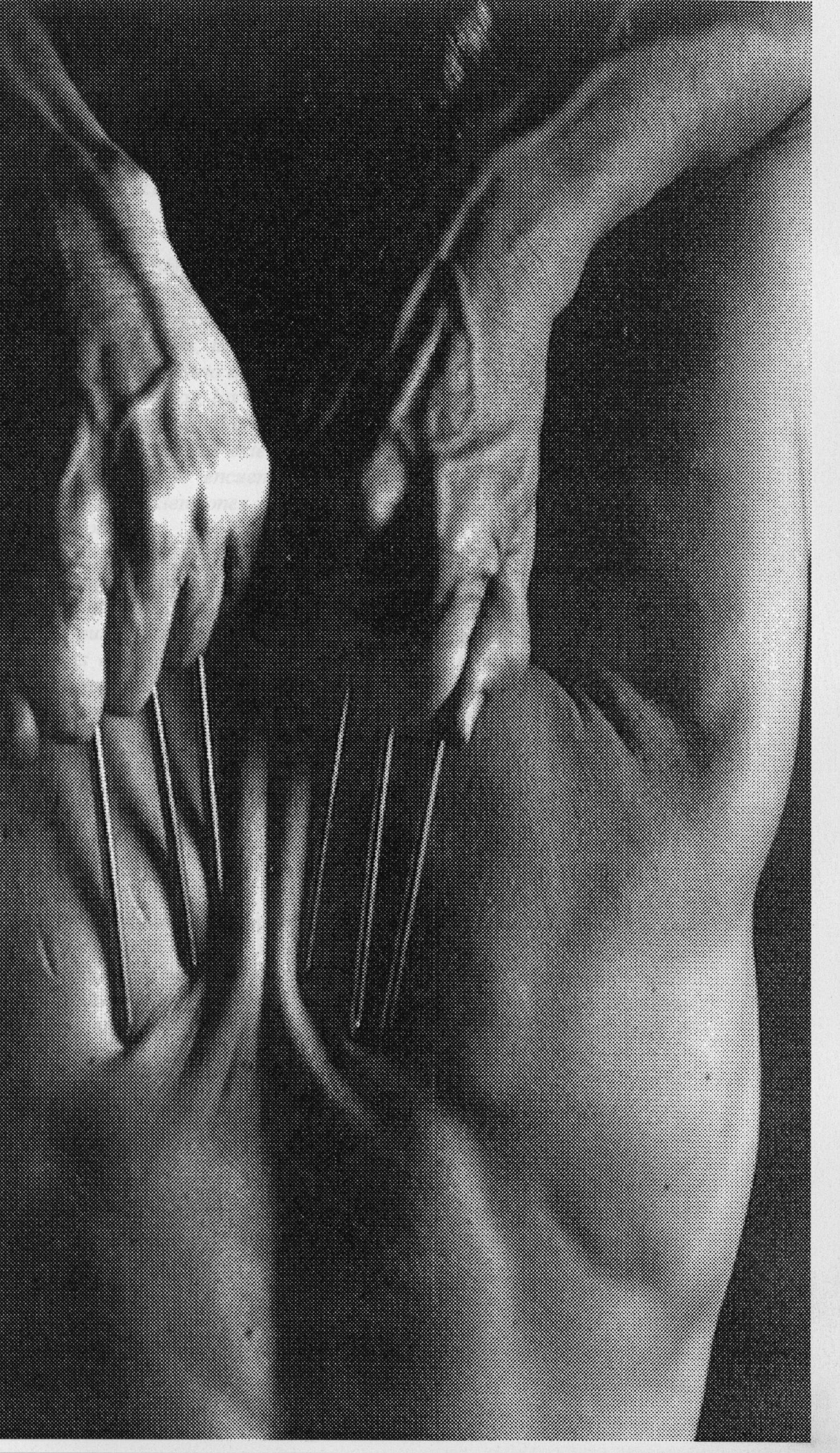


naturaleza; lo constitutivo del cuerpo es, incluso, insuficiente para preparar una ofrenda cara a la deidad. Herir como regalo, ofender como ofrenda, lastimar como ofrecimiento, dolor como dádiva. Renuncia, entrega, servicio, bodigo, monda, libamiento. Inmolación de las penas perforando la respiración; pudiera ser la última estocada.

Ilustración: Sacrificio colectivo

(Ballet del siglo XX de Maurice Béjart)

Se alcanzan a ver trece cuerpos masculinos con los torsos desnudos a la mitad de la oscuridad, alineados en cuatro filas, la primera -de izquierda a derecha - de cuatro, la segunda de cinco, la tercera y la cuarta de dos. Todos a la vez en una gran salto realizado con las piernas abiertas y extendidas, los torsos lanzados hacia atrás, lo que provoca que se resalten las costillas; prolongando el arqueo están las cabezas, que se pierden dejando ver tan sólo las barbillas. Los brazos extendidos se lanzan hacia arriba y hacia atrás rematando en las manos, que se encuentran extendidas al máximo con los dedos completamente abiertos. Las extensiones de todos los miembros emulan un conjunto ordenado de X. Entrega total.

Al unisono la entrega de los cuerpos pende de un grito suspendido que estalla hacia lo alto. Apertura total que apela a una atención probablemente ausente entre tanta oscuridad; la fuerza conjunta-revelada en todos los torsos que parecieran reventar en el esfuerzo, en las cabezas que arrojadas hacia atrás cancelan el rostro, abandonan su individualidad, en los brazos lanzados hacia lo alto, en la manos extendidas al máximo en un reclamo y un regalo y una súplica y una sublimación. Los largos paños que cubren piernas y cintura no alcanzan a ocultar la intensidad que anima el impulso. Los cuerpos totales y la totalidad de los cuerpos se entregan a la vorágine creada en la uniformidad de la dinámica. Confabulación, comunión, concierto o réquiem. Es menester otorgarse, es deber ofrendarse; blandir los cuerpos como emblemas de sacrificio. Torbellino caudaloso sólo posible en la congregación de las fuerzas; cada una y todas juntas potencian el estertor de la anhelada inmolación.

La confesión es el primer e indispensable paso de la expiación en tanto que actividad propia del sujeto para consigo mismo y por ende, para con los demás. La penitencia es una serie de actos tendientes a conseguir el perdón de los pecados cometidos. El sacrificio es una ofrenda que busca la expiación y que, por ello se encuentra vinculado con la penitencia y la confesión. Y todo ello para aligerar el peso de la culpa; darle al cuerpo para liberar el alma.

Sin embargo, pese a todo humano esfuerzo, la culpa es incurable, "el hombre debe rechazar como indigno de él todo posible perdón de su culpa. Una vez que se ha cargado con la propia culpa, no es posible dejársela quitar sin negarse a sí mismo. El culpable tiene derecho a soportar su propia culpa (...) el perdón de su culpa es imposible porque ellos lo rechazan como humillación inaceptable, porque, de otro modo, el culpable permanece en su decisión tomada contra dios" (Ibid: 110-111). Es decir, pecar es la imposibilidad de cualquier otra posibilidad: el hombre fue, es y será culpable. 
Dentro del sistema de transformaciones del cuerpo, tal y como ha sido establecido, para el cristianismo ser humano es sinónimo de ser culpable; es decir, la culpa forma parte intrínseca de la condición de ser de la humanidad. El modelo tras el cual construye la adopción engendrada de la culpa, por cierto y paradójico, es el de la oposición negativa entre pecado y virtud, en donde la primacía está colocada en la última, pues es la ausencia de las virtudes lo que le ha conseguido su estatus a la humanidad y a los individuos, al igual que la oposición positiva entre pecado y expiación, pues lo uno lleva necesariamente a lo otro. El sistema de funcionamiento es sencillo: existe una relación positiva entre culpa y pecado, así como entre culpa y expiación, y entre pecado y expiación y negativa entre culpa y virtud, así como entre pecado y virtud.

Reconocer a qué entidades pertenecen las nociones trabajadas permite saber el tipo de relación que mantienen todas ellas. Así como las ideas puras y la templanza se vinculan por su condición de posibilidad, la culpa y el pecado original lo hacen por su negación de cualquier otra posibilidad; la cotidianeidad del yo, su conducta, su proceso estarán determinados cuando se actualicen. Será entonces la actualización en bruto, el hacer del aquí, la experiencia de los actos que podrá ser significativa y lo será cuando se vinculen los universos arriba señalados, cuando la dureé del ahora y las acciones lleguen al momento del drama liminal, del pecado cometido que tendrá, necesariamente, que pagarse con un eterno sacrificio.

La culpa, el pecado original, la templanza y la confesión se incardinan directamente en el proceso cotidiano de la conducta del yo, creando un modelo que forma parte, principalmente, de lo real del sujeto. Todas estas categorías entendidas como posibilidad, o sea la condición de ser o existir independientemente de cualquier otra cosa, se convierten en condición paradigmática que se activará, solamente, en la actualización de todos los elementos.

En su caso, los pecados veniales, la fortaleza y la penitencia se incardinan directamente en la experiencia significativa de los actos del aquí; son la estructura que forma parte, principalmente, del imaginario de la experiencia. Todas estas categorías corresponden a hechos concretos que son en la medida en que cobran sentido, debido a que se vinculan con las categorías arriba señaladas.

Por último, los pecados mortales, la justicia y el sacrificio son o se activan en los dramas sociales, liminales, y son parte fundamental de la trascendencia de las acciones del ahora, lo que los vuelve componente fundamental del sistema de lo simbólico de la cultura. Todas estas entidades son las que dotan de cabal sentido a todas las señaladas anteriormente es decir, todos los pecados, las virtudes, la confesión y la penitencia-- pues son las que, al unificarlas, crean la trama y la urdimbre de la culpa, tal y como es concebida por el cristianismo. Una variante en alguno de los elementos analizados o de sus relaciones, crearía una transformación en la totalidad, pues se activan y son en la medida en que así están organizadas. La culpa es una posibilidad que, cuando se ponen en juego los pecados, las virtudes y la expiación, adquiere la contundencia que tiene.

Cualquier sujeto es posible de formarse según sea, pero una vez que acepta el bautizo se convierte en cristiano y, mientras, se bautiza como pecador que asume su condición de 
culpable, y el sujeto que ha adoptado el cristianismo y con ello la culpa, vive siempre en la tensión entre pecado y prudencia; la templanza lo mantendrá como sabedor de ser derivado del pecado original, aunque le permitirá tener un corazón ordenado; la fortaleza le evitará cometer pecados al igual que la justicia, aunque será también ésta la que lo castigará si finalmente su pecado es mortal.

De este modo, la cotidianeidad del sujeto, lo quiera o no, estará permeada por los pecados veniales, lo que le marcará los hechos significativos, o bien liminales si el pecado es mortal. Ésta cualidad le obligará a la confesión permanente y, de seguro, a mantenerse en penitencia si el pecado es venial, y en franco sacrificio, sobre todo ahí donde el pecado sea mortal, aunque de ser así nunca alcanzará el perdón, sólo el permanente deambular por el purgatorio. Esto es lo que el cristianismo ha dicho que la culpa es, donde lo real mediatizado por lo simbólico transforma el imaginario y constituye a un sujeto que se vive como culpable. La vivencia del cuerpo-para-si se ve alterada cuando la percepción, el imaginario se confronta con la interpretación simbólica del otro.

Pero la fuerza de la culpa no se detiene en los que se han asumido como cristianos. Una buena parte del conjunto de ideas consolidado por el cristianismo -y su antecedente, el judaísmo--, ha encarnado en la sociedad actual con displicencia. Normas sociales que se han internalizado de tal manera que no se necesita ser creyente para ser culpable, el mecanismo de esta vivencia se activa en infinidad de conductas, actos y acciones de cualquier sujeto. Estar lejos o abandonar esta religión, no dirime la intensa vivencia, tan poco sutil, tan encarnada, tan dominante de la culpa.

El cristianismo ha llevado a la humanidad a un punto sin retorno, a la dependencia absoluta y perpetua, y a nombrado al cuerpo humano como el símbolo del mal y de la maldad. Y en la medida en que la condición propia de la humanidad es ser mortal y que ello es un castigo debido a la desobediencia de los primeros hombres, el pecado original no se queda en la ingenuidad de una parábola bíblica, sino que trasciende cualificando el modo de ser de la humanidad: si se es humano es porque se es culpable. El bautizo, que pretendería limpiar la falta primigenia, en realidad la actualiza cada vez: bautizarse significa adoptar el cristianismo, y con ello asumir que se es lo que se es por una falta.

El cristianismo ha instaurado un sólido aparato de culpabilización que internalizado - a la manera foucaultiana del poder - y asumida la doctrina que lo constituye, ha creado cuerpos que se viven como ontológicamente culpables. Si bien se insiste en establecer la dicotomía entre cuerpo y alma, ello no significa que el cuerpo se haya mantenido en el olvido; por el contrario, ha sido sobre el cuerpo donde se han marcado múltiples sentencias. Tecnologías y estrategias como la de la culpa, mantienen el control sobre el cuerpo y, por lógica indefectible -dado que cuerpo es sujeto y no hay sujeto sin cuerpo- en el hombre. El proceso de internalización de la culpa -donde algo o alguien designa ese estado, en este caso la religión-- ha sido asumido; la culpa no es asunto que pudiera evitarse u omitirse, pues si se es humano se es culpable: marca, designio, conformación, estatuto... sentencia.

El cuerpo, que es el dato terrenal de la existencia, es el mortal, por lo tanto el cuerpo es la marca que acusa permanentemente y a la vista de todos, y será el cuerpo lo que se deberá 
mantener siempre bajo control pues es el punto más frágil, el que indefectiblemente se inclina al pecado.

Concebidos por la maldad, como pecadores, ello es siempre el estigma que obliga a vivir a los humanos en el temor y la obediencia, en la perpetua vigilancia del cuerpo, pues sólo si se es capaz de seguir al pie de la letra una vida de virtudes --asunto poco probable-- se estará libre de pecado. Pero como es poco probable, la cotidianeidad enseña que infinidad de actos se convierten, por su trascendencia, en acciones significativas y ellas son en principio pecados veniales: nuevamente el modo de ser del hombre es el de pecador, tanto por que se lleva a cuestas la falta primigenia, como porque todos los días se actualiza con los pecados veniales. "Tomó entonces Pilato a Jesús, y mandó azotarle. Cada golpe que recibió Jesús, lo aceptó por amor a nosotros. Su espalda y su pecho quedaron convertidos en una gran llaga. ¿No es verdad que seguimos siendo sus verdugos cuando cometemos algún pecado?" (San Juan, en Baduí Dergal, 2001: 19).

La obligatoriedad de la expiación confirma que lo predominante es el pecar; si no, para qué tener que confesarse frecuentemente. Pero no sólo, sino que dicha expiación incrementa el sufrimiento y habrá que preguntarse porqué es a través del dolor que es posible dirimir una pena: al sufrimiento de haber pecado habrá, entonces, que sumarle el sufrimiento de la penitencia o del sacrificio. Un dolor de un tipo debe ser menguado por uno de otro tipo ad infinitum, ad nauseam. Sin embargo, no hay salida posible, pues el acento se ha colocado en la falla: el cristianismo concibe al hombre no como virtuoso que llega a pecar, sino como pecador que podrá, si se esmera, ser virtuoso.

Para el cristianismo el cuerpo es, por sí mismo, una falla que contiene, potencialmente, todas las fallas posibles; por ende, debe estar supeditado a aquello que sí tiene la capacidad de ser puro, lo único que puede acercarse verdaderamente a dios: el alma. Sólo a través de un espíritu ordenado se puede estar en comunión con el creador; el cuerpo nunca dejará de pecar, por ello deberá estar subordinado, siempre opacado y el alma será, permanentemente, dependiente de dios.

Y serán los cuerpos los que revelen lo antedicho; toda alteración de la postura del hombre -la concordancia entre los ejes vertical, horizontal y sagital-- revela su interior; toda alteración de la tensión de los miembros y articulaciones viene de o va hacia algo, es algo, dice algo. La cabeza sube, baja, gira; el rostro se enfrenta o se afronta, mira o se esconde; el cuello se tensa, se agiganta, se hunde o simplemente permanece; el torso se encorva cóncavo o convexo, está suelto o se dilata; los brazos, las manos -tan expresivas como el rostro--, en toda su movilidad, llevan, traen, apoyan, sujetan, son y están y siempre hablan; el vientre tiene fuerza o se hace el fuerte o debe permanecer bajo fuerza o es fortaleza; la pelvis $-y$ su compleja marca de sexualidad - va hacia el frente o se enconcha hacia atrás; las piernas, los pies, no sólo caminan, se encorvan, se expanden, se contracturan; se abren y se cierran entre sí y por sí.

El cuerpo vivido deambula como es, así como el cuerpo percibido e interpretado lo han marcado; los contenidos alteran las formas. No sólo el rostro y las manos hablan del ser y añaden contenido a la verbalidad; la gestualidad del cuerpo en su totalidad es por algo y eso es lo que dice, eso es lo que es posible leer. Al menos como occidente ha enseñado, toda vez que 
la posición del pecho $-\mathrm{y}$ sus conexiones inmediatas: los omoplatos, las clavículas, los hombros-- se modifica es porque existe dolor, miedo, vergüenza, vanidad o extrema tensión. Principalmente el vientre revela la atención que se le da al cuerpo -en cuanto a ejercitamiento y alimentación-mas también es el sostén de la parte superior del cuerpo, y la fuerza que imprime en su quehacer revela lo pesado de su carga, no sólo en cuanto a kilos, sino en cuanto a sensaciones, sentimientos, vivencias, percepciones. La espalda, ese engañoso envés, es el sostén de la humanidad misma. La colocación de la pelvis es portadora de cuantiosa información pues es el continente privilegiado de la infinidad de discursos sobre el sexo, amén de ser el centro de gravedad del cuerpo. Las piernas y los brazos en toda su movilidad revelan fuerza o laxitud, energía o pasividad, seguridad o inseguridad, definición o temor; qué tanto se suben los brazos, se alejan del torso, qué tan amplio es su movimiento; las piernas están cerradas sobre sí o son firmes, fuertes o nerviosas, sostienen con firmeza o se doblan. Las manos y los pies se transforman al hablar, al caminar, al vivir; se expanden o se contraen, son fuertes o se dilatan, hay en ellos entereza o resignación. Cada músculo, tendón, nervio, arteria, articulación, órgano, miembro, se modifica por la alimentación, el ejercicio, las vivencias, las imágenes, las percepciones, la realidad, las interpretaciones, las significaciones, los sentidos, los simbolismos: la experiencia.

\section{Ilustración: La caída}

(Intérprete: Kazuo Ono)

1) Un hombre de pie, firme, piernas robustas y sólidas van hacia el frente; un calzoncillo que trasluce potencia, un torso erguido marcado por la osamenta. Los brazos levantados sostienen una tela que cae en sus espaldas, misma que cubre la cabeza y enmarca un adusto rostro; será la luminosidad pero sólo se alcanzan a ver las cuencas de los ojos. La nariz, las narinas y la boca entreabierta revelan un gesto que desprende soberbia, ira, avaricia, lujuria quizá. Parece poderoso, sin duda, en su extrema tensión se revela que lleva la fuerza del mal.

2) Mas aparece de nuevo con toda la furia convertida en caída. Las piernas, que se veian sólidas, ahora están enjutas; los pies lo detienen pero apenas colocados en el piso. Las rodillas se doblan, el torso también. Los brazos ya no sostienen nada, han tirado la tela y se constriñen hacia el cuerpo. La tensión sube, desgarradoramente, hacia el cuello asentado en sobresalientes claviculas que develan encorvamiento enfatizado por los omoplatos que parecen descolocarse. Las arterias rectas van hacia el rostro marcado por el dolor, tiene cara de náusea, vómito y desesperación.

3) Está a punto de caer. La tela, tan fuerte y airosamente levantada, lo ha abandonado, yace a los pies que apenas lo sostienen. Las piernas, completamente dobladas dejan ver hasta los huesos. El torso no tiene fuerza y la piel luce desgastada, corroída, corrompida. El brazo derecho doblado cubre el torso y la mano, que también cae, levanta el meñique como último suspiro. El brazo izquierdo evita que el desplome sea total, prepara la caída. La tensión del cuello disminuye y se va hacia el rostro en el que se adivinan, de tan demacrado, los huesos. Parecen cuencas, orificios con un poco de ajada piel. Súplica y desesperanza. 


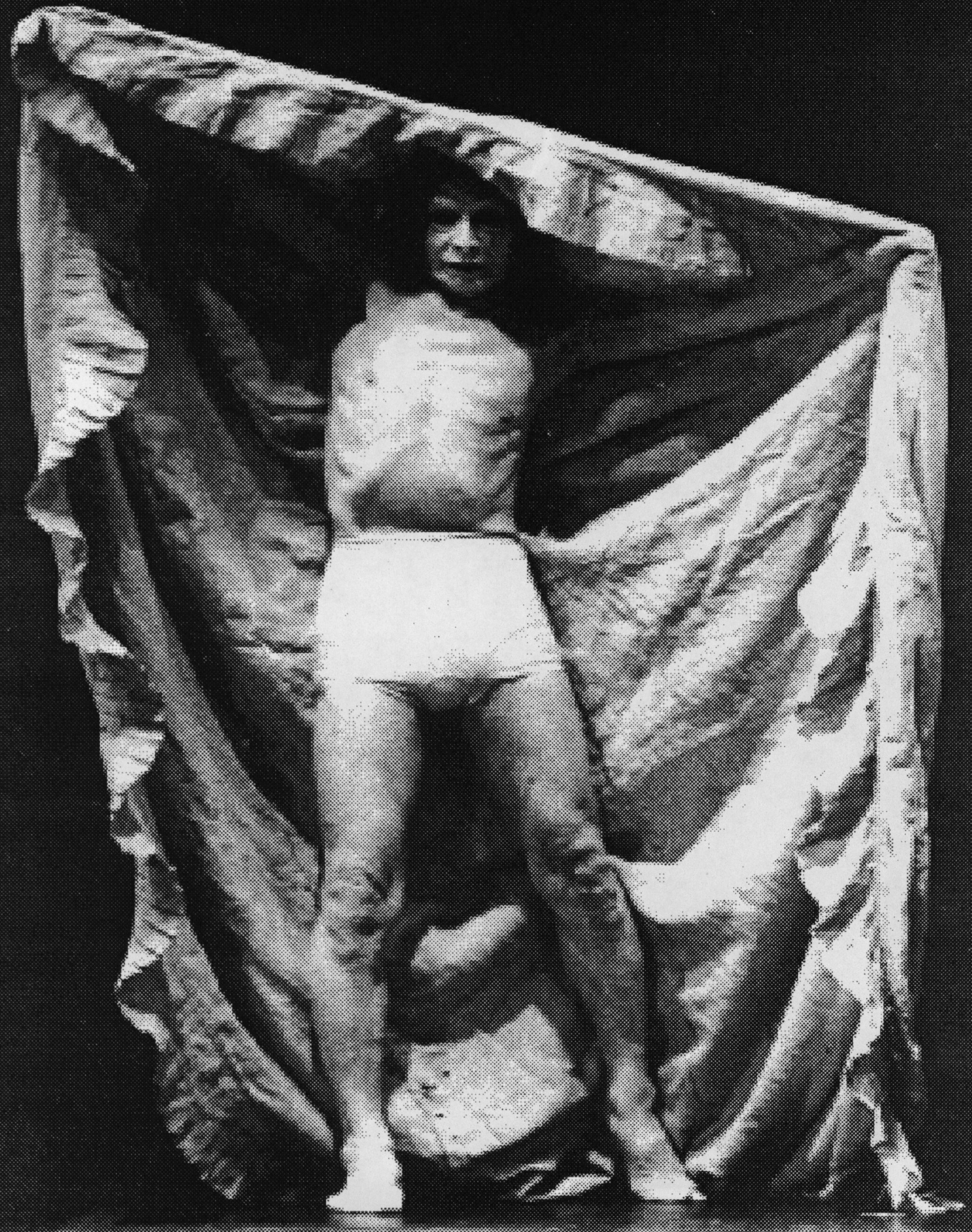




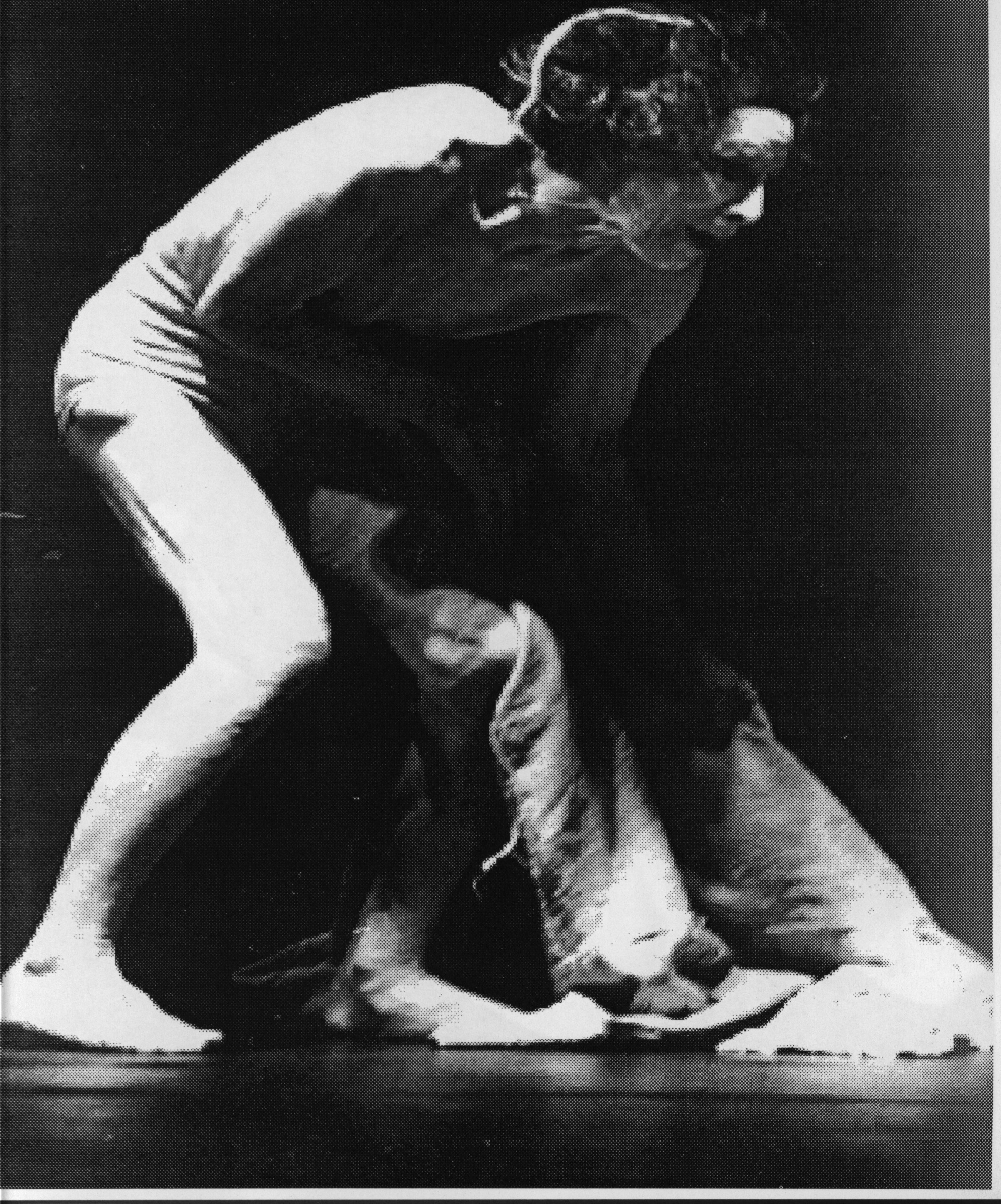


4) Su peso ha llegado al suelo y sigue cayendo, talones e isquiones lo sostienen. Los pies estáticos, las rodillas dobladas, juntas, contritas; hueso y piel. El torso se dobla; la osamenta se adivina bajo la piel corrugada. Los brazos siguen pegados al torso, doblados hacia adentro al igual que las manos caidas tiesas, deformadas. La cabeza ladeada muestra de frente un rostro demacrado, con ojeras, arrugado. Hay arrepentimiento, fatiga, resignación; todavia alcanza a suplicar levemente.

5) Y cae aún más, casi todo su peso está en la pierna derecha que se dobla para sostenerlo. Los dedos de los pies se crispan, las piernas ya no sostienen nada. Del torso cubierto por el brazo izquierdo sólo se observa la corrompida piel y los huesos, extremadamente resaltados del hombro y la clavícula. Lo que evita la caída total es el apoyo de la mano - de tensos dedos-- y el brazo derecho --pero ya se doblan-- y del codo izquierdo, cuya mano intenta sostener la cabeza que tiene un rostro que ya sólo mira hacia su tumba. Falta poco, el cuerpo lo sabe: enjuto, diezmado, acabado, se derrumba.

6) Ya ha caído. Yace en el piso sin fuerza, mas no tendido sino agotado, doblado sobre su costado. La pierna derecha sobre el piso se dobla hasta casi llegar al pecho, la otra la acompaña poco más extendida. La cadera se ha vencido, el torso, cubierto con árida piel, echado hacia delante, incrementa la torsión. El brazo derecho lánguido sirve de reposo a la cabeza. Del brazo izquierdo sólo queda el hombro como muñón. Hueso y piel; algunas venas crispadas. Boca cerrada, ojos cerrados, arrugas, marcas. Ya ha caído y el gesto sigue siendo de dolor, el triunfo de la angustia. Pecador cuya fuerza lo ha llevado al derrumbe total. Culpable por ser, culpable por pecar, culpable por morir. Culpable, por los siglos de los siglos, por mandato divino. Culpable nació y por su culpa murió.

Incardinado, a gusto o no, en la sociedad actual, el cristianismo ha estigmatizado el cuerpo a perpetuidad. El cuerpo, que es la posibilidad de la existencia, de la cognición, eje rector, vínculo con el mundo, modo de ser..., para ésta dominante religión es la actualización del mal. Los cuerpos, los sujetos, el hombre, la humanidad, ha quedado marcada "por los siglos de los siglos" por la fervientemente dolorosa, intransigente, inalterable, inevitable... culpa. 


\section{Bibliografía}

Agustín, San, Confesiones, Sarpe, Madrid, 1983.

Aisenson, Aida, Cuerpo y persona, Fondo de Cultura Económica, México, 1981.

Aulagnier, Piera, "Nacimiento de un cuerpo, origen de una historia", Luis Hornstein, Piera Aulagnier, Maria L. Pelento, et al., Cuerpo, historia, interpretación, Piados, Buenos Aires, 1991.

Baduí Dergal, Julio, Los pecados capitales, Minos, México, 2001.

Bataille, Georges, Las lagrimas de Eros, Tusquets, Barcelona, 1997.

Baudrillard, Jean, De la seducción, Rei, México, 1997.

Bauman, Zygmunt, La cultura como praxis, Paidós, Barcelona, 2002.

Berger, Peter L. y Thomas Luckmann, La construcción social de la realidad, Amorrortu, Buenos Aires, 1999.

Bourdieu, Pierre, "La creencia y el cuerpo", El sentido práctico, Taurus, Madrid, 1991.

Carrizosa Hernández, Silvia (compiladora), Cuerpo: significaciones e imaginarios, UAMX, México, 1999.

Díaz Cruz, Rodrigo, Archipiélago de rituales. Cinco teorias antropológicas del ritual, Tesis de Doctorado en Antropología, UNAM, México, 1995.

-----, “Antropología del cuerpo: los escenarios rituales y performativos", ponencia presentada en el ciclo de conferencias: Antropología, arte y cultura, CENIDI Danza, José Limón, México, 28 de agosto del 2001.

Douglas, Mary, Pureza y peligro, Siglo Xxi, Madrid, 1973.

Fages, Jean-Baptiste, Para comprender a Lacan, Amorrortu Editores, Buenos Aires, 1993.

Foucault, Michel, Microfísica del poder, Ediciones de La Piqueta, Madrid, 1992.

----- La arqueología del saber, Siglo XXI, México, 1995.

-----, $\quad$ Vigilar y castigar, Siglo XXI, México, 1995. 
-----, Historia de la sexualidad 2- el uso de los placeres, Siglo XXI, México, 1999.

Historia de la sexualidad 3- la inquietud de sí, Siglo XXI, México, 1999.

-----, $\quad$ Historia de la sexualidad. 1- la voluntad de saber, Siglo XXI, México, 2000.

Freud, Sigmund, "El yo y el ello", Obras completas III, Biblioteca Nueva, Madrid, 1981.

Gennep, Arnold van, Los ritos de paso, Taurus, Madrid, 1986.

Gombrich, E. H.., Art and illusion. A study in the psychology of pictorial representation, Phaidon Press, London, 1962.

Graham Cole, William, Amor y sexo en la Biblia, Grijalbo, México, 1964.

Heidegger, "El origen de la obra de arte", Helena Cortés y Arturo Leyte, Caminos de bosque, Alianza, Madrid, 2000.

Johnson, Mark, El cuerpo en la mente, Debate, Madrid, 1991.

Julien, Philippe, El retorno a Freud de Jacques Lacan. La aplicación al espejo, SITESA, México, 1992.

Lacan, Jacques, Escritos 1 y 2, Siglo XXI, México, 1988.

Ladaria, Luis F., Teología del pecado original y de la gracia, Sapientia Fidei, Biblioteca de autores cristianos, Madrid, 2001.

Le Breton, David, Antropología del cuerpo y modernidad, Nueva Visión, Buenos Aires, 1995.

Leroi-Gourhan, André, El gesto y la palabra, Universidad Central de Venezuela, Caracas, 1971.

Lévi-Strauss, Claude, Lo crudo y lo cocido. Mitológicas I, Fondo de Cultura Económica, México, 1968.

-----, $\quad$ Antropología estructural, Eudeba, Buenos Aires, 1977.

-----, $\quad$ El pensamiento salvaje, Fondo de Cultura Económica, México, 1975.

------ La via de las máscaras, Siglo XXI, México, 1981

-----, $\quad$ Antropología estructural. Mito, sociedad, humanidades, Siglo XXI, México, 1983. 
Mauss, Marcel, "Las técnicas del cuerpo", Journal de Psychologie, XXXII, 3-4, Paris, 1936.

Merleau-Ponty, Maurice, Fenomenología de la percepción, Península, Barcelona, 2000.

-----, $\quad$ La estructura del comportamiento, Hachette, Buenos Aires, 1976

Miller, Jacques-Alain, El seminario de Jacques Lacan. Libro 2, Paidós, Buenos Aires, 1988.

Panofsky, Erwin, Estudios sobre iconología, Alianza Universidad, Madrid, 1972.

Peirce, Charles Sanders, La ciencia de la semiótica, Ediciones Nueva Visión, Buenos Aires, 1986.

-----, Obra lógico semiótica, Taurus Comunicación, Madrid, 1987.

-----, "Un argumento olvidado a favor de la realidad de Dios", Gérard Deladalle, Leer a Peirce hoy, Gedisa, Barcelona, 1996.

Pérez Cortés, Sergio, "El individuo, su cuerpo y la comunidad", Alteridades, 1, 2, UAM-I, México, 1991.

Pieper, Josef, El concepto de pecado, Herder, Barcelona, 1986.

----- $\quad$ Las virtudes fundamentales, RIALP, Madrid, 2001.

Sartre, Jean-Paul, El ser y la nada, Losada, Buenos Aires, 1972.

Schilder, Paul, Imagen y apariencia del cuerpo humano, Piados, México, 1994.

Schütz, Alfred, La construcción significativa del mundo social, Piados, Barcelona, 1993.

Sennet, Richard, Carne y piedra. El cuerpo y la ciudad en la civilización occidental, Alianza, Madrid, 1997.

Turner, Victor, La selva de los símbolos, Siglo XXI, Madrid, 1980.

-----, $\quad$ From Ritual to Theatre, PAJ Publications, New York, 1982.

-----, El proceso ritual. Estructura y antiestructura, Taurus, Madrid, 1988.

----- $\quad$ Dramas, Fields and Metaphors. Symbolic Action in Human Society, Cornell University Press, Ithaca, 1994. 
Volli, Ugo, "Técnicas del cuerpo", Hilda Islas (compiladora), De la historia al cuerpo y del cuerpo a la danza, INBA/CONACULTA, México, 2001. 